\title{
ANL SMALL-SAMPLE CALORIMETER SYSTEM DESIGN AND OPERATION
}

by

\author{
C. T. Roche, R. B. Perry, R. N. Lewis, \\ E. A. Jung, and J. R. Haumann
}

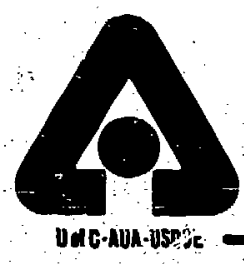

\section{ARGONNE NATIONAL LABORATORY, ARGONNE, ILLINOIS Operated for the U. S. DEPARTMENT OF ENERGY}


ANL-NDA-1

ISPO-13

ANL SMALL-SAMPLE CALORTMETER

SYSTEM DESIGN AND OPERATION

by

C. T. Roche, R. B. Perry, R. N. Lewis,

E. A. Jung, * and J. R. Haumann *

Nondestructive Assay Section

Special Materials Division

ARGONNE NATIONAL LABORATORY

9700 South Cass Avenue

Argonne, Illinois 60439

MOTGE

PORTIONS GE TUS DEPOTT ARE ULEGB!E. It bosen nom the bost available cepy to fermis the broadest possible availability.

July 1978

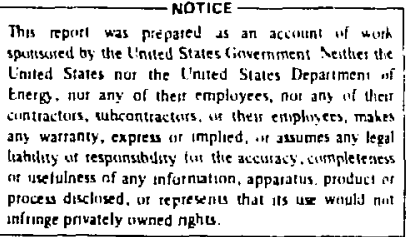

*E1ectronics Division 
TABLE OF CONTENTS

Page

I. INTRODUCTION ........................ 1

II. IAEA SMALL-SAMPLE CALORTMETRIC SYSTEM . . . . . . . . . 3

A. Environmental Operating Conditions ......... 3

B. System Setup ............... 4

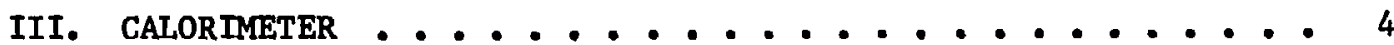

A. Physical Description............ 4

B. Calorimeter Checkout and Adjustment ........ 9

IV. DATA ACQUISITION SYSTEM (DAS) .............. 10

A. Physical Description .............. 10

B. Keyboard Action-Response ............. 11

V. RECOMMENDED PROCEDURES . . . . . . . . . . . . . 16

A. Sample Encapsulation . . . . . . . . . . 16

B. Assay Procedure ................. 16

$\therefore$ Electrical Calibration Procedure . . . . . . . 19

VI. DATA ANALYSIS ................... 21

A. Effective Specific Power ............. 21

B. Analysis of Sample Power . . . . . . . . . 24

APPENDIX A: CALORIMEIRIC UNIT CIRCUIT DIAGRAMS $\# 1-12 \ldots \ldots$

APPENDIX B: DATA ACQUISITION SYSTEM (DAS) . . . . . . . 47

I. Circuit Dlagrams $\# 1-7 \ldots . . . . . . .48$

II. Listing of Microprocessor Program . . . . . 55

APPENDIX C: OPERATING INSTRUCTIONS WITH SAMPLE OUTPUT TAPE $\quad \cdot \quad 96$

I. Simplified Operating Instructions ...... 96

II. Explanation of Typical Output Tape . . . . . 97 


\section{LIST OF ILLUSTRATIONS}

Figure

$\underline{\text { Page }}$

1. The ANL small-sample calorimetric syscen . . . . . . . 2

2. Schematic of the front panel of the calorimeter module.............. 5

3. A block diagram of the small-sample calorimeter with its measurement and control components . . . . 7

4. Internal assembly of calorimeter module ....... 8

5. Resistance thermometry and feedback control circuitry in ANL air-chamber calorimeters . . . . . . 25

6. Data acquisition flowchart ............. 26

7. The measurement-chamber temperature and power relations in ANL air-chamber calorimeters . . . 27 
ANL SMALL-SAMPLE CAIORTIETER

SYSTEM DESIGN AND OPERATION

by

\author{
C. T. Roche, R. B. Perry, R. N. Lewis, \\ E. A, Jung, and J. R. Haumann
}

\title{
I. INTRODUCTION
}

The Small-Sample Calorimetric System (Fig. 1) is a portable instrument designed to measure the thermal power produced by radioactive decay of plutonium-containing fuels. The mass of plutonium in a sample is related to the measured power through the weighted average of the product of the 1sotopic decay energies and the decay constants of the plutonium isotopes present. The urantum content of the fuel will not affect the measurement, since the thermal power produced by the uranium nuclides is insignificant when compared to plutonium. This is the result of the longer half-life of uranium relative to the $\mathrm{Pu}$ isotopes. The principal radiations from plutonium are alpha particles and low-energy photons. As a consequence of the low penetration power of this radiation, greater than $99.9 \%$ of the decay energy will be degraded to thermal energy measurable by the small-sample calorimeter. (A more detalled discussion of the physical principles involved in calorimetry is Included in A Portable Calorimeter System for Nondestructive Assay of (fixced-Oxide Fuels, ISP0-16.)

The small-sample calorimeter is capable of measuring samples producing power up to 32 milliwatts at a rate of one sample every 20 minutes. This power corresponds to sampies contalning approximately $10 \mathrm{~g}$ of low burn-up plutonium oxide. The measurement precision for the baseline power $\left[\sigma\left(\mathrm{P}_{0}\right) / \mathrm{P}_{0}\right]$ is better than $0.1 \%$. Samples containing $1.5 \mathrm{~g}$ of plutonium $(2.5 \mathrm{~mW})$ have to be assayed within this precision. The small-sample calorimeter can assay unknowns having milligram amounts of plutonium; however, the measurement prectsion may deteriorate.

The instrument is contained in two packages; a data-acquisition module consisting of a microprocessor with an $8 \mathrm{~K}$-byte nonvolatile memory, and a mea- 


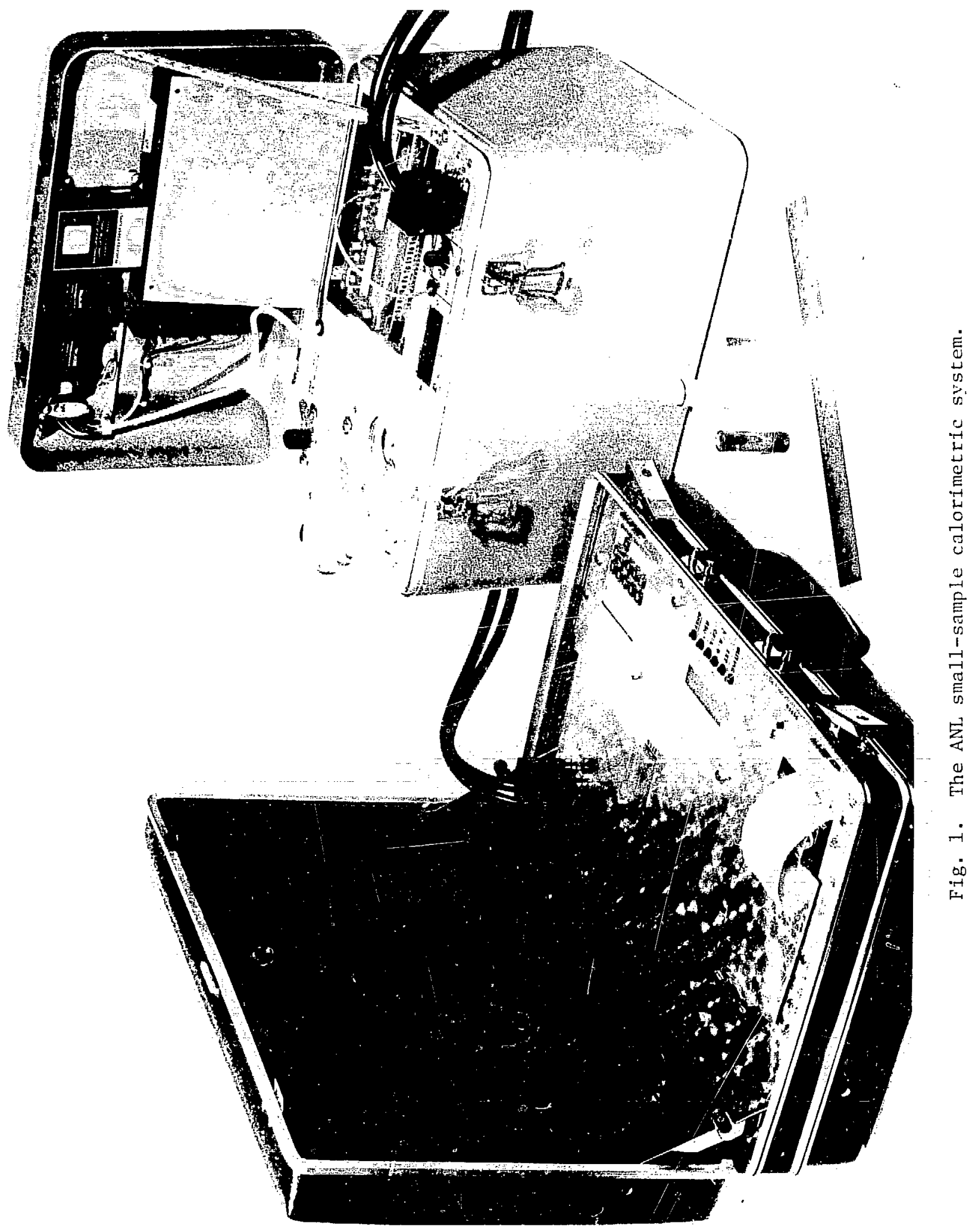


aurement module consisting of the calorimeter and a sample preheater. The total welght of the system is $18 \mathrm{~kg}$.

\section{IAEA SMALL-SAMPLE CALORIMETRIC SYSTEM}

The Small-Sample culorimetric sysem (Seco) is a portable instrument designed for in-field operatton. Care hat heen taken to minlmize the effects of nonideal environments encouncured during the couse of a typical assay. Ficld conditions have been simulated in the lahoratory, and a set of operating conditions which ensure maintenance of $a 0.1 \%$ meisuremont precision have been developed. Aithough these operating requiremen are bruad and should not restrict the inspector, reasonable care should be exereisud in choosing a sampling location. Operation in any unfamiliar setting should be preceded by is callibration and a thorough check-unt.

\section{$\therefore$ Fnvironmental Ojeratirg Condic ions}

\section{Temperature}

The calorimeter unit is adjusted for a misimum sumple power of 32 riw. The temperatures of the cuencentric ahambers comprising this unit are: $\mathrm{T} \because 45.1^{\circ} \mathrm{C} ; \mathrm{T}_{2}, 44.4^{\circ} \mathrm{C} ; \mathrm{T}_{1}, 42.9^{\circ} \mathrm{C} ; \mathrm{T}_{0}, 40.7^{\circ} \mathrm{C} ; \mathrm{T}_{A}, 39.7^{\circ} \mathrm{C}$. The system was tested in an environmental chamber between $10.5^{\circ} \mathrm{C}$ and $35.0^{\circ} \mathrm{C}$. Over this temperature range, a drift ir the measurament precision of less than $0.1 \%{ }^{\circ} \mathrm{C}$ was experienced.

\section{Power Requirements}

The IAFA SSCS is designed to be operaied with a voizage of either $110 \mathrm{VAC}(60 \mathrm{~Hz})$ or $220 \mathrm{VAC}(50 \mathrm{~Hz})$. The device was tested for voltage fluctiation with a ?10-VA: ine. Operation was unaffected by fluctuations under 20\%. The calorimeter was also nperared on a power line exhibiting $\pm 8 \mathrm{v}$ noise spikes. No degradation in performance was observed. 


\section{B. System Setup}

\section{Line Voltage Selection}

The appropriate line voltage (110 VAC or $220 \mathrm{VAC}$ ) MUST be selected before attaching the power cable. The line-voltage selection switch is 1ocated in the cover of the calorimetric unit. Attempted operation of this device in the wrong power mode may result in serious damage to the unit.

\section{System Interconnection}

The calorimeter and its data-acquisition system (DAS) MUST be connected prior to applying line voltage. The multipin connectors on the calorimetric unit, labeled $P 1, P 2$, should be connected to their respective receptacles on the DAS. Two identicai AMP cables, which are stored in the DAS case, are provided foz this purpose.

\section{Power Up}

A North American standard three-prong power cord is provided to attach the SSCS to the building power line. After the system has been set up, it must be allowed to reach equilibrium at operating temperature before assaying samples. This takes approximately two hours at $20^{\circ} \mathrm{C}$.

\section{CALORTMETER}

\section{A. Physical Description}

The calorimetric unit is housed in a $30-\mathrm{cm} \times 41-\mathrm{cm} \times 26-\mathrm{cm}$ drawn-aluminum case and has a total weight of $13 \mathrm{~kg}$. The layout of the various components is shown in Fig. 2. Detalled circuit schematics are provided in Appendix

The heart of the unit is the CALORIMETRIC SAMPLE CHAMBER which is comprised of four (4) temperature-controlled regions. These regions are constructed from a set of concentric aluminum cylinders upon which noninductive heater coils 


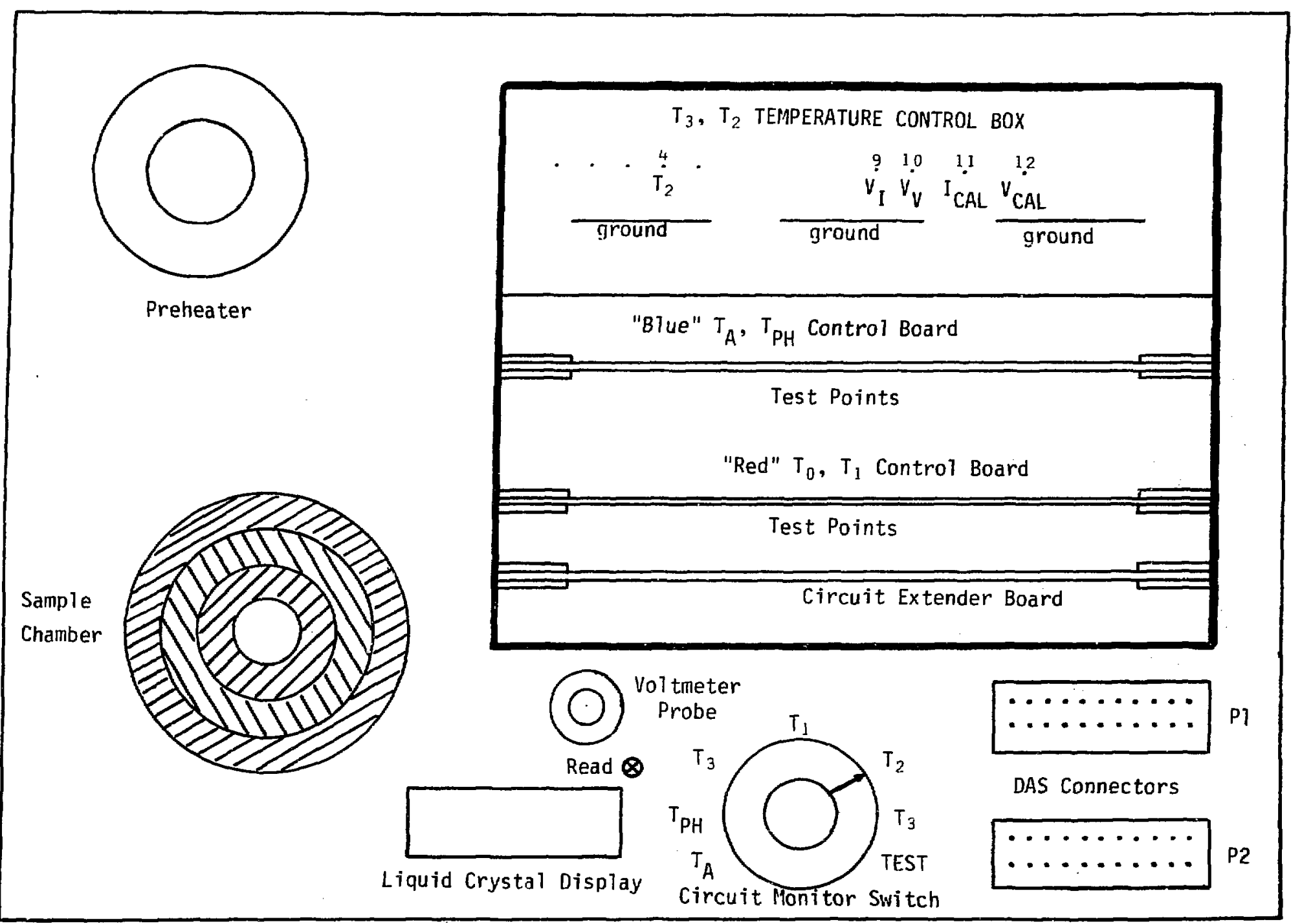

Fig. 2 Schematic of the front panel of the calorimeter module. 
and temperature-sensitive elements are mounted. The cylinders are set at increasingly higher temperature as the center is approached $\left(T_{0}<T_{1}<T_{2}\right.$ $\left(\mathrm{T}_{3}\right)$, and are insulated from each other by styrofoam. This design ensures that the heat flow will remain constant in the outward radial direction. The entire assembly is encapsulated in styrofoam (see Figs. 3, 4).

Adjacent to the sample chamber is the SAMPLE PREHEATER in which capsules containing material to be assayed are brought to the temperature of the inner cylinder $\left(\mathrm{T}_{j}\right)$. Preheating the sample in this manner greatly reduces the waiting period for the sample to reach equilibrium.

The CIRCUIT MONITOR SWITCH enables the operator to measure the temperatures and voltages of various points within the calorimeter. The locations of these test points are given in Appendix A. The results will be shown on the LIQUID CRYSTAL DISPLAY (LCD). Temperatures are continuously monitored by YSI thermistors, with the exception of $\mathrm{T}_{3}$. In order to measure the temperature of the most sensitive inner coil $\left(T_{3}\right)$, the button labeled READ must be depressed. This connects the thermistor to the measurement circuit. The TEST position on this switch enables the user to monitor various points in the control circuits with an on-board digital voltmeter (DVM) in conjunction with the TEST PROBE.

The operator may obtain access to the temperature-control circuits through the lid in the upper right-hand corner of the instrument face. The control circuits are located on three plug-in type printed-circuit boards which may be removed for servicing. The inner coil $\left(\mathrm{T}_{2}, \mathrm{~T}_{3}\right)$ circuits are housed in a temperature-controlled box $\left(\mathrm{T}_{A}\right)$ in the rear of the cavity. Final testing of these boards should be performed in their temperaturecontrolled environment. The circuits for the less sensitive regions are 1ocated on the blue $\left(\mathrm{T}_{1}, \mathrm{~T}_{0}\right)$ and red $\left(\mathrm{T}_{A}, \mathrm{~T}_{\mathrm{PH}}\right)$ boards. In order to facilitate circuit testing and calibration, a cirucit-extender board is supplied. A set of fifty (50) test points are supplied to assist the operator in troubleshooting the device. The locations and expected values of these points are given in the TEST POTNT TRUTH TABLE (Appendix A). 


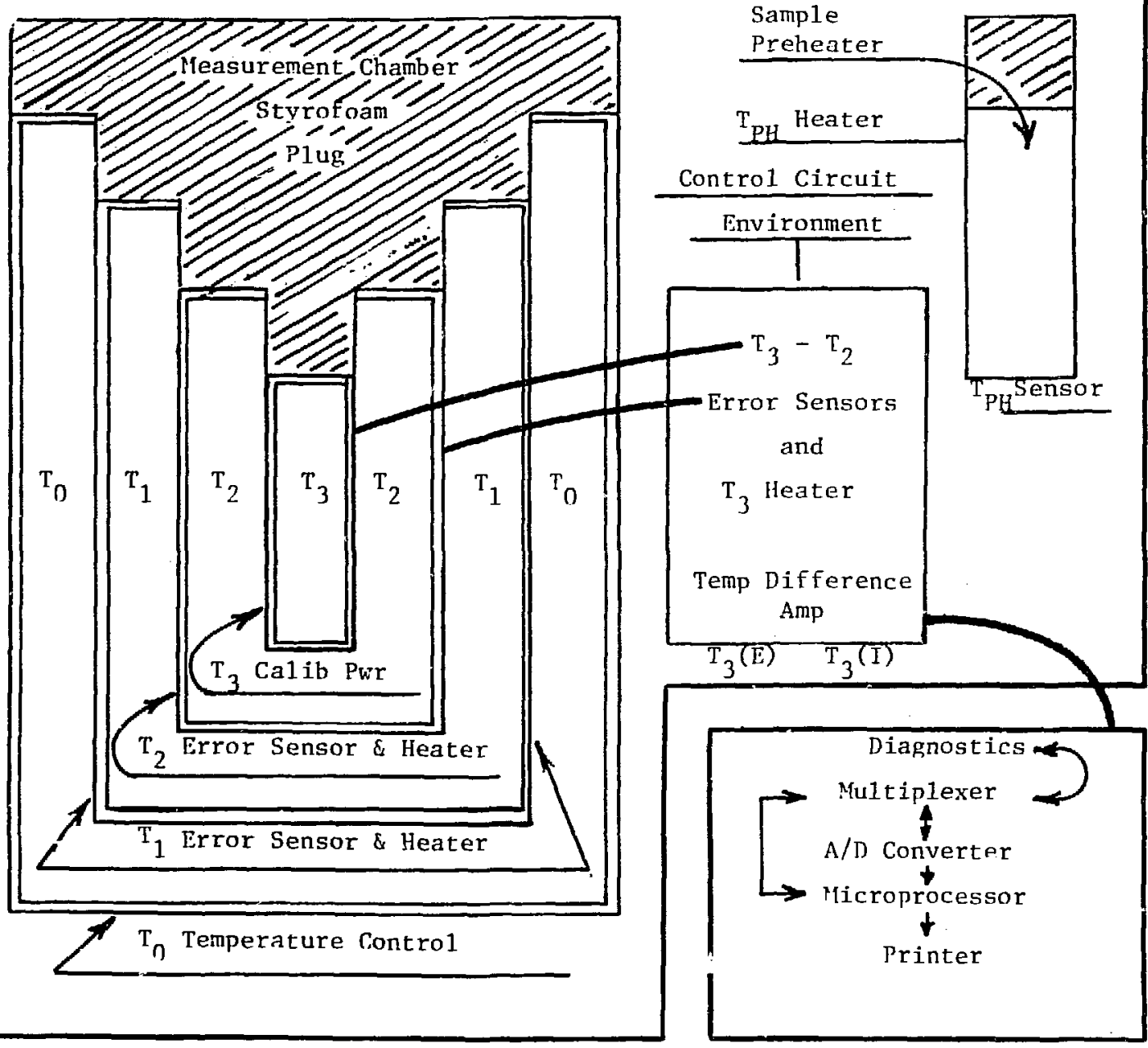

Fig. 3. A block diagram of the small-sample calorimeter with its measurement and control components. 


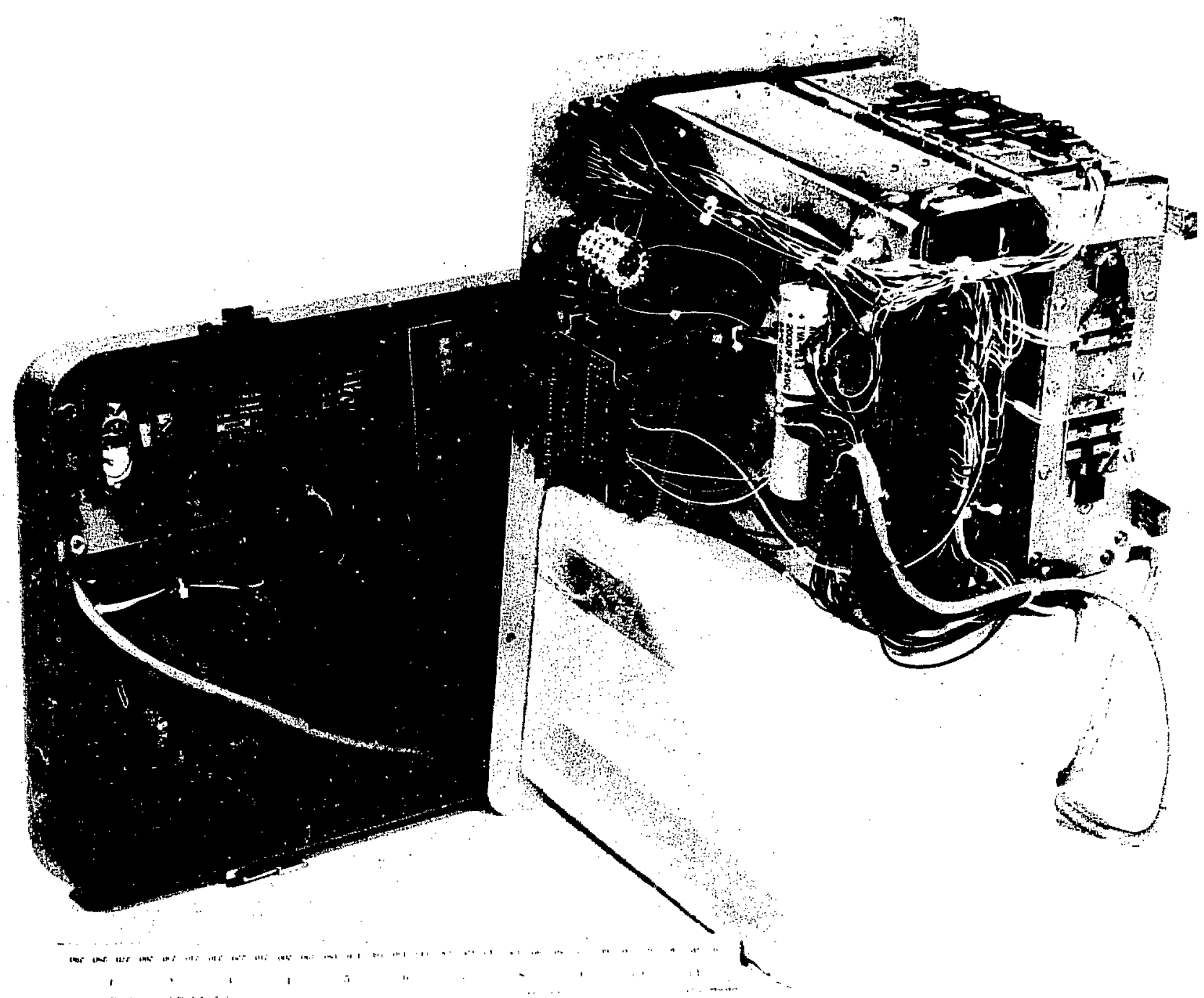

Fig. 4. Internal assembly of calorimeter module. 
B. Calorimeter Checkout and Adjustment

The calorimetric control cizcuits have been adjusted for a maximum sample power of $32 \mathrm{~mW}$ at a room temperature of $20^{\circ} \mathrm{C}$. This permits a maximum sample size of about $13 \mathrm{~g}$ of $2 \mathrm{PR}-3$ fuel $\left({ }^{238} \mathrm{Pu}<0.1 \%,{ }^{239} \mathrm{Pu} \sim 94.7 \%\right.$, $\left.{ }^{240} \mathrm{Pu} \sim 5.1 \%,{ }^{241} \mathrm{Pu} \sim 0.2 \%,{ }^{241} \mathrm{Am}-0.2 \%\right)$. If it is necessary to assay samples emitting larger amounts of heat, the following procedure should be performed.

NOTE: The Instrument is very sensitive to the temperature-power settings. Changes in these settings should only be made by tralned personnel (preferably at $\mathrm{ANL}$ ). It is recommended that the user make these adjustments ONLI IF ABSOLUTELY NECESSARY.

1. Place the microprocessor in the RESET mode (press RST). This insures that no electrical calibiation power will be accidentally applied to the inner chamber $\left(\mathrm{T}_{3}\right)$.

2. Calculate the approximate desired voltage for the inner coils.

$$
E=\sqrt{P \times R} \quad R=900 \Omega
$$

3. Adjust the $T_{3}$ cofl to the desired voltage. The measurement chamber, $\mathrm{T}_{3}$, is adjusted by manipulating the T3TEMP pot while monitoring the $\mathrm{T} 3$ coil voltage [TP10 $\left(V_{V}\right)$ on the TA box]. The T3TEMP pot is a $25-t$ urn $5-\Omega$ pot in the A5A amplifler feedback loop which controls the temperature set point. The immediate effect of this adjustment will be to send the control circuits into either saturation (maximum power applied) or cutoff (no power applied). Sufficient time must then be allowed for the instrument to stabilize at the new operating conditions. In general, only $\mathrm{T}_{3}$ should need adjustment; however, any changes necessary to preserve the coil relation $\mathrm{T}_{3}>\mathrm{T}_{2}>\mathrm{T}_{1}>\mathrm{T}_{0}$ should be made at this time. T2 is monitored on TP4 while T2TEMP pot is changed. T1 and TO are monitored using on-board DVM while adjusting the labeled pots on the "blue" printed-circuit board. (After completion $f \mathrm{f}$ this adjustment, the next section, 4 , must also be performed.) 
4. Calibrate $T_{3}$ heater-coil electrometer. This adjustinent is made by zeroing the $T_{3}$ amplifier $A 5 A_{1}$ The $T_{3}$ zurrent output, TP9, should be monitored during this operation. Depress the PUSH FOR $\mathrm{V}_{\mathrm{I}}$ ZERO button to isolate A5A. While this button is depressed, adjust $\mathrm{V}_{\mathrm{J}}$ ZERO pot so TP9 is zeroed to within $10 \mu \mathrm{V}$. Next, connect a high-impedance DVM across callbration points TP13 and TP14. Adjust $V_{I} C A L$ for $0.0000 \mathrm{~V} \pm 10 \mu \mathrm{V}$.

NOTE: While monitoring TP9, the DVM should be grounded to the ground posts on the $\mathrm{T}_{\mathrm{A}}$ box.

5. Calibrate electrica: calibration coil electrometer. This procedure adjusts the amplifier A5B network which controls the electrical calibration. Connect a jumper from TP12 ( $\left.\mathrm{V}_{\mathrm{CAL}}\right)$ to TP15 $\left(-\mathrm{I}_{\mathrm{CAL}}\right)$ to isolate A5B. Adjust ${ }^{-I_{C A L}}$ ZERO pot to zero TP15 within $10 \mu \mathrm{V}$. Adjust $+\mathrm{I}_{\text {CAL }}$ ZERO pot to zero TP11 within $20 \mu \mathrm{v}$.

6. Reference voltage calibration. The $10 \mathrm{~V}$ and $1 \mathrm{~V}$ reference voltages are read from TP16 and TP17. These may be adjusted by manipulating the appropriate pots on $T_{A}$ box.

NOTE: Aiways adjust $+10 \mathrm{~V}$ pot first.

IV. DATA ACQUISITION SYSTEM

\section{A. Physical Description}

The Data Acquisition System (DAS) is housed in a $47 \mathrm{~cm} \times 35 \mathrm{~cm} \times 16 \mathrm{~cm}$ attaché case anó has a total weight of $5 \mathrm{~kg}$. It is a totally dedicated microprocessor-controlled device, designed around the INTEL 8085. The system memory consists of $8 \mathrm{~K}$ byces of erasable, programmable, read-only memory (EPROM) and $1 \mathrm{~K}$ bytes of random-access memory (RAM). The program resides in the permanent memory, EPROM, and does not need to be reentered after the device is powered down. The EPROM is organized on four 2K-byte INTEL-2716 chips, the 1ast $2 \mathrm{~K}$ bytes being exchangable. The RAM is organtzed on four 256-byte INTEL-8156 chips and serves as scratch-pad storage for the program. The microprocessor receives input either from the calorimeter through the 
12-bit ADC or from the 25-key multifunctional keyboard. System output is through either the BOMAR TP3120-2 printer or the Liquid Crystal Display (LCD). A set of 6 LEDs are available to reflect system status. Detailed schematics and a copy of the $\mu \mathrm{P}$ program are included in Appendix B.

\section{B. Keyboard Action-Response}

1. RST $\equiv$ Restart

Function: To place the system in an idle mode, where it will monitor the keyboard for a user command. All data processing is stopped. System default values are restored. The results of any uncompleted calculation will not be available to the user. The system will return to this mode after completing any noncyclical routine.

Use: This key should be used when first powering-up the system or when aborting a particular routine.

\section{Status Light: READY}

Printer: "SMALL SAMPLE READY"

2. ENTR $\equiv$ Enter

Function: To signal the end of a numeric input.

Use: This key should be used when responding to a $\mu \mathrm{P}$ prompt statement with a numerical value. It also acts as a "NO" in a situation requiring a YES/NO response.

Printer: Carriage return - Line feed

3. $\quad$ BS $\equiv$ Backspace

Function: To permit the user to erase an undesired response to a $\mu \mathrm{P}$ prompt statement. 
Use: This key repositions the input ASCII array by one character each time it is pressed.

Printer: Backspace

4. EXT $\equiv$ Execute external program

Function: To enable to user to expand the computational abilities of the DAS. The DAS is designed so that the last $2 \mathrm{~K}$ of the $8 \mathrm{~K}$ PROM memory is interchangeable by replacing the chip in the zero force socket with a different INTEL 2716 containing a new program.

Use: To be determined by user.

Status Light: EXT

Printer: Program dependent.

5. TP $\equiv$ Diagnostic test points

Function: To enable the user to examine the voltages of any of 32 selected locations within the calorimeter. (See Appendix A for TP locations within the calorimeter.)

Use: This routine may be used either to continuously monitor a particular point on the Liqujd Crystal Display or to obtain a printout of all 32 points. To change TP during continuous monitoring, press "TP" and the number of the desired test point. Use RST to exit from continuous monitoring.

Status Light: A/D

Liquid Crystal Display: TP voltage 
Printer: "TEST PNTS"

$$
\begin{aligned}
& \text { "ALL?" - - LP prompt statement } \\
& \text { User Response - YES - all TP's printed (Option 1) } \\
& \text { - \#, ENTR - individual TP displayed } \\
& \text { (Option 2) }
\end{aligned}
$$

6. PRINT $\equiv$ Print

Function: To allow user to obtain a printed record of a test point which is being continuously monitored or of a power which is being displayed on the Liquid Crystal Display.

Printer: Numeric output

7. INIT $\equiv$ Inttial data input

Function: To permit the user to input parameters which will be used in the data analysis by the $\mu \mathrm{P}$.

Use: Input isotopic mass \% + uncertainty, elapsed time since last isotopic analysis, default value of effective specific power, power normalization factor, system uncertainty.

Status Light: RSVP after $\mu \mathrm{P}$ prompts

Printer: "DATA INPUT MASS \%"

"AM241" - $\mu$ P prompt statement

A $\mu \mathrm{P}$ prompting statement will be printed for ${ }^{241} \mathrm{Am}$ and for each isotope ${ }^{238-242} \mathrm{Pu}$. After each prompt, enter the isotopic mass \% and its uncertainty. (Note: 1) Include the leading zero in numbers less than 1.0, i.e., type 0.01 , not .01. 2) Ar \% is defined as; [Mass (Am)/Mass (Pu)] $\times 100$.

$$
\text { "TIME-DAYS" }
$$

Enter the time elapsed since last isotopic analysis was performed. 
"POWER $\mathrm{mW} / \mathrm{g} "$

Enter a default value if it is decided not to calculate the Effective Specific Power from the isotopic mass fractions.

"P NORM"

This parameter relates the measured thermal power to a calibrated source-produced power (f.e., $P_{\text {measured }}=P_{\text {source }} \div$ PNORM). A value of 1.0 was experimentally determined and is included as a default value. This value may be altered if necessary (see Sections $V$, VI).

\section{"SIG(SY)"}

This parameter contains the nonstatistical contributions to the measurement precision. The default value is zero, meaning no sys tematic error is included. We have experimentally determined the systamatic uncertainty in the power measurement. If the operator wishes to include this factor, he should enter a value of 0.028 (approx. 0.1\% relative standard deviation) after performing a " $\mathrm{P}_{0}$ " and before a "RUN". The components of this parameter are discussed in Section VI. (NOTE: The default values of PNORM and SIG(SY) are restored after an RST).

NOTE: The remaining keys (FRAC, SP, $P_{0}, \mathrm{RUN}$, and CAL) activate major subroutines used in data acquisition and analysis. Brief descriptions are given below. More detailed discussions are included in the sections on Recommended Procedures and on Data Analysis.

8. FRAC $\equiv$ Mass Fraction decay correction

Function: To calculate the changes in the mass percentages in a previously isotopically analyzed sample resulting from radioactive decay. A current set of mass \% will be generated which may be used to calculate effective specific power. 
Use: The program requires that the initial mass \% and the elapsed time be encered through INIT prior to execution.

Printer: The decay-corrected isotopic mass \% are printed.

9. SP $\equiv$ Effective Specific Power calculation

Function: To determine the power emitted per gram of the material to be assayed as well as the uncertainty associated with this calculation.

Use: The program requires that the mass \% be available prior to execution.

Printer: The effective spectfic power and its uncertainty.

10. $P_{0} \equiv$ Empty chamber baseline analysis

Function: To determine the power supplied by the calorimeter to maintain a constant temperature when no heat-producing source is present.

11. RUN $\equiv$ Samp1e assay

Function: To determine the calorimeter-supplied power in the presence of a Pu-containing material; to compare this with he empty chamber results and derive the sample power and mass.

12. CAL $\equiv$ Electrical calibration

Function: To supply a series of known electrical powers to the sample chamber, and to determine the resulting measured powers, thus allowing the user to derive a relation between the measured and actual sampie power.

NOTE: A simulated output tape showing the results of typical operations is given in Appendix C. 


\section{RECOMMENDED PROCEDURES.}

\section{A. Sample Encapsulation}

The sample containers supplied with the Smal1-Sample Calorimeter are designed to maximize the rate of heat transfer and to thus decrease the sample assay time. The encapsulation technique chosen by the IAEA inspectors will depend on the physical state of the material (solid, powder, or 1iquid) and may differ from facility to facility. The system equilibration time will vary depending upon the material used in constructing the sample holders. With the double-metal technique developed at ANL, a measurement precision of $0.1 \%$ can be obtained in an equilibration time of $15 \mathrm{~min}$. However, experiments using sources double-bagged in polyethylene showed ait increase of the equilibration time to $30 \mathrm{~min}$. A double-encapsulation technique should be used to decrease the chance of radioactive contamination of the instrument. Regardless of the method chosen, it is important to minimize the air gap between the sariple and the inner chamber walls. It is also important to determine the length of the equilibration time PRIOR to using the instrument in an assay situation.

\section{B. Assay Procedure}

1. Remove previously assayed sample from SAMPLE CHAMBER.

NOTE: a) The settling time of this system is strongly dependent upon the degree to which the unit is disturbed during the process of sample changing. A procedure should be developed which will minimize the length of time during which the sample and sample chamber are exposed to ambient-temperature conditions. The same sequence should be followed during all assays.

b) The lid of the sample chamber is constructed from styrofoam and is fragile.

c) The sample holder has been machined to fit the sample chamber with a close tolerance. Samples should be removed slowly 
from the chamber to avoid creating a suction which might alter the crientation of the inner chamber.

2. Remove the sample to be assilyed lrom the PREHEATER, Insert it in the SAMPLE CHAMBER, and replace the 1id.

WOTE: Do not force the sample holder into the chamber. Allow it to settle by gravity.

3. Place the next sample in the PREHEATER.

It is important that the samples be preheated prior to insertion into the sample chamber. Lack of preheating can increase the equilibration time by a factor of four ( $x 4)$. A sample should be allowed to preheat for approximately one measurement cycle (delay time plus data acquisition time).

4. Reset microprocessor-controlled DATA ACQUISITIGN SYSTEM.

Operator Action: Press RST

System Response: "SMALL SAMPLE READY"

5. a) Sample Baseline Reading

$\begin{array}{lll}\text { Operator Action: } & \text { Press } \underline{P_{0}} \\ \text { System Response: } & \text { "EMPTY MEAS" } \\ & \text { "PRINT ALL?" (Print each PWR } \\ & & \text { neasurement) }\end{array}$

Operator Action: $\quad \underline{Y E S}=$ Yes

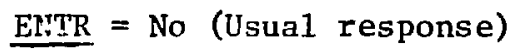




\begin{tabular}{|c|c|}
\hline System Response: & $\begin{array}{r}\text { "DELAY-MIN" (delay period to permit } \\
\text { system to equilibrate) }\end{array}$ \\
\hline Operator Action: & $\begin{array}{c}15 \text { ENTR (Note: This value may differ } \\
\text { with sample composition.) }\end{array}$ \\
\hline System Response: & $\begin{array}{c}\text { "SIGMA-\%" (Lfmit of acceptable precisior } \\
\text { of } \overline{\mathrm{P}} \text { ) }\end{array}$ \\
\hline Operator Action: & $\begin{array}{l}0.02 \text { ENTR }(2 \sigma 1 \mathrm{imit}) \text { If the operator } \\
\text { wishes the instrument to repeatedly } \\
\text { measure the same sample, enter } 0.0001\end{array}$ \\
\hline System Response: & "非DP/RUN" ( ( $25 \mathrm{DP} / \mathrm{min}$ ) \\
\hline Operator Act & 100 ENTR (4 min) \\
\hline
\end{tabular}

The system then enters the DATA ACQUISITION MODE, and the following sequence will occur:

1) The E.I products are monitored until $\overline{\mathrm{P}}<35 \mathrm{~mW}$. This indicates that the heater circuits are no longer in saturation, and the system is approaching equilibrium.

2) The system enters an operator-determined delay period during which no data is accepted.

3) The $\mu \mathrm{P}$ accepts $\mathrm{E}$, I digital data from the ADC. The E.I product is calculated. An operator-determined number of data points is collected. The value of the calorimeter applied power and the number of data points $1 \mathrm{eft}$ to be acquired are alternately displayed on the 1iquid crystal display. (Note: Numbers greater than 256 will not be displayed.) $\overline{\mathrm{P}}$ and the sample standard deviation of the mean are calculated. The results are compared with "SIGMA-\%". If the precision is acceptable, the data is stored and printed; otherwise, a new set of data will be accumulated. 
4) The system is reset if the experiment is not to be repeated.

5. b) Sample Assay

$$
\begin{aligned}
& \text { Operator Action: Press RUN } \\
& \text { System Response: "MEAS" }
\end{aligned}
$$

At this point, the operator's options are identical to those just discussed in Section 5.a, above. An examp1e of a set of typical responses and the results of an assay are shown in Appendix $C$.

\section{Electrical Calibration Procedure}

1. Place preheated dummy sample (capsule containing a nor-heatproducing mass) in the SAMPLE CHAMBER.

NOTE: P1ease refer to Section B of the Recommended Procedures for instructions on sample handling.

2. Perform a sample baseline reading $\left(\underline{P}_{0}\right)$. (See Section 5.a of recommended Assay Procedure.)

NOTE: This assay is not used in the calibration calculation. The purpose of this measurement is to ensure that the system is at equilibrium and to provide a check on the calibration-determined empty chamber intercept $\left(P_{0}\right)$.

3. Reset DAS (if necessary).

4. Electrica1ly calibrate system.

Operator Action: Press GAL

System Response: "CALIBRATE"

"CAL PNTS" ( $\mu \mathrm{P}$ prompt statement) 
Operator Action: 5 ENTR This determines the number of points used to calculate the calibration parameters.

At this point, the same set of options discussed in Section 5.a of the Recommended Procedures is available. The following responses are suggested, since they produce an accurate set of fitting parameters within a 75-min period. Thus the calibration sequence may be set up to complete itself during a lunch break.

\begin{tabular}{lc}
$\mu \mathrm{P}$ Prompt Statement & Operator Response \\
\cline { 2 - 2 } CAL PNTS & 5 \\
DELAY MIN & 7 \\
SIGMA \% & 0.02 \\
\#DP/KUN & 100
\end{tabular}

The $\mu \mathrm{P}$ determines the incremental calibration voltage by dividing the empty chamber power by the number of calibration points. This value will be added to the applied calibration voltage through a digital analog converter. The microprocessor will then enter the operator-selected decay period to permit the system to reach equilibrium. Since the measurement chamber is not disturbed by changing the sample between calibration voltage increases, the time necessary to reach equilibrium is significantly shorter than in an actual assay. Equilibrium will be reached in as few as five (5) minutes. (A delay period of 7 min is suggested.) The operator-determined \#DP/RUIis are then collected and analyzed, and then the $\mu \mathrm{P}$ measures the input calibration voltage. The data is printed, and the process is repeated for the next calibration point.

After the calibration has been completed, the operator may extract the zero-power intercept, and the power linearity factor (slope) with a linear least squares fitting technique. This calculation is discussed in the Data Analysis section of the manual. Measurement of the power slope gives a value of -0.995 . However, the associated uncertainties of the measurement, and a cross-calibration with a known $\mathrm{Pu}$ heat source have led us to recommend a value of 1.0 for PNORM. 


\section{A. Effective Specific Power}

In order to obtain maximum utility from the calorimeter, the measured sample power must be combined with additional isotopic information to determine the plutonium content of the sample. If the unknown contains only one isotope of plutonium, the generated heat is related to the sample mass by $t^{\prime} \cdot e$ equation

$$
\mathrm{W}_{\mathrm{U}}=2.1193 \times \mathrm{M} \times \mathrm{Q} / \mathrm{T}_{\frac{1}{2}} \times \mathrm{A}
$$

where

$$
\begin{aligned}
& \mathrm{W}=\text { power }(\mathrm{mW}) \\
& \mathrm{M}=\text { mass of } \mathrm{Pu}(\mathrm{g}) \\
& \mathrm{Q}=\text { total disintegration energy (MeV) } \\
& \mathrm{T}_{\frac{1}{2}}=\text { half-li }=\text { ef the isotope of } \mathrm{Pu}(\mathrm{yrs}) \\
& \mathrm{A}=\text { gram atomic weight }(\mathrm{g})
\end{aligned}
$$

Under normal assay conditions, nuclear fuel will contain a mixture of radionuclides, the principal power producers being $238-242 \mathrm{Pu}$ and ${ }^{241} \mathrm{Am}$. Consequently, the sample power may be obtained from

$$
W_{U}=M \cdot \Sigma R_{i} \cdot P_{i}=M \cdot P_{\text {eff }}
$$

where

$$
\begin{aligned}
& \mathrm{R}_{i}=\text { mass fraction of the radionuclide } \\
& \mathrm{P}_{i}=\text { specific power of a } \mathrm{Pu} \text { isotope mW/g } \\
& P_{\text {eff }}=\text { effective specific power of the sample }
\end{aligned}
$$

Two techniques are suggested for determining the effective specific power. ${ }^{1}$ Representative samples may be subsequently analyzed chemically to determine the $\mathrm{Pu}$ content $(\mathrm{mW} / \mathrm{g})$. This method usually requires multiple measurements distributed in time to account for isotopic decay. The second 
technique requires that the isotopic composition be determined by gamma-ray or mass spectrometry. ${ }^{2}$ Determination of radionuclide abundances by gamma-ray spectrometry has the advantage of being nondestructive and may be conducted concurrently with a calorimetric analysis. While the method chosen may differ from assay to assay, the programs supplied will work with either technique.

\section{Radioactive-Decay Correction}

The isotopic mass ratios are contirually changing owing to radioactive decay within the sample. In particular, the beta decay of ${ }^{241} \mathrm{Pu}$ to ${ }^{241} \mathrm{Am}$, which is a short-lived alpha emitter, results in an increase in the effective specific power with time. If a detalled isotopic analysis of the sample material has been made at an earlier date, an on-site determination of the mass fractions may be unnecessary. The present composition may be calculated by means of the folluwing decay equations:

$$
\begin{aligned}
& F_{1}=F_{i}^{0} \cdot \exp \left(-\lambda_{i} t\right) / \Sigma F_{1}^{0} \cdot \exp \left(-\lambda_{i} t\right) \\
& F_{A M}=\left[1 / \Sigma F_{i}^{0} \cdot \exp \left(-\lambda_{i} t\right)\right] \cdot\left\{F_{A M}{ }^{0} \cdot \exp \left(-\lambda_{A M} t\right)\right. \\
& \left.+\left[\lambda_{241} \cdot F_{241} /\left(\lambda_{241}-\lambda_{A M}\right)\right] \cdot\left[\exp \left(-\lambda_{A M} t\right)-\exp \left(-\lambda_{241} t\right)\right]\right\}
\end{aligned}
$$

where

$$
\begin{aligned}
& \mathrm{F}_{i}^{0}=\text { mass \% of } \mathrm{Pu} \text { 1sotope at last analysis }
\end{aligned}
$$

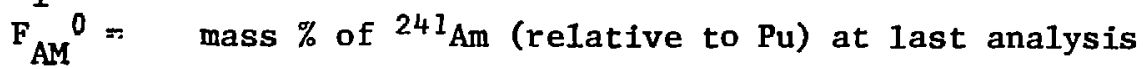

$$
\begin{aligned}
& \lambda_{1}=\text { decay constant of } \mathrm{Pu} \text { isotope }\left(\text { day }^{-1}\right) \\
& \lambda_{\mathrm{AM}}=\text { decay constant of }{ }^{24{ }^{1} \mathrm{Am}}\left(\text { day }^{-1}\right. \text { ) } \\
& t=\text { time elapsed since last analysis (days) }
\end{aligned}
$$




\section{Isotope}

${ }^{238} \mathrm{Pu}$

$239 \mathrm{Pu}$

${ }^{240} \mathrm{Pu}$

${ }^{241} \mathrm{Pu}$

$242 \mathrm{Pu}$

${ }^{241} \mathrm{Am}$
Decay Constant $\left(\right.$ day $\left.^{-1}\right)$

$$
\begin{array}{ll}
2.1617 & \cdot 10^{-5} \\
7.880 & \cdot 10^{-8} \\
2.903 & \cdot 10^{-7} \\
1.322 & \cdot 10^{-4} \\
5.08 & \cdot 10^{-9} \\
4.372 & \cdot 10^{-6}
\end{array}
$$

The $8080-\mu \mathrm{P}$ code for these calculations is given in Appendix $B$.

\section{Effective Specific Power Calculation}

The effective specific power is defined as the weighted sum of the isotopic specific powers. The uncertainty in this value is dependent upon the measurement errors in both the isotopic mass fractions and the specific power.

$$
\begin{aligned}
P_{\text {eff }} & =\sum_{i} F_{i} \cdot P_{i} / \sum_{i} F_{i} \\
\sigma^{2}\left(P_{\text {eff }}\right) & =\sum_{i}\left(\frac{F_{i} P_{i}}{F_{i}}\right)^{2}\left(\frac{\sigma^{2}\left(F_{i}\right)}{F_{i}{ }^{2}}+\frac{\sigma^{2}\left(P_{i}\right)}{P_{i}{ }^{2}}\right)
\end{aligned}
$$

where

$$
\begin{array}{ll}
F_{i} & \text { mass } \% \text { of the radioisotope } \\
\sigma\left(F_{i}\right) & =\text { uncertainty in } F_{i} \\
P_{i} & =\text { isotopic specific power }(\mathrm{mW} / \mathrm{g}) \\
\sigma\left(P_{i}\right) & =\text { uncertainty in } P_{i}(\mathrm{~mW} / \mathrm{g}) \\
P_{\text {eff }} & =\text { effective specific power }(\mathrm{mW} / \mathrm{g}) \\
\sigma\left(P_{\text {eff }}\right) & =\text { uncertainty in } P_{\text {eff }}(\mathrm{mW} / \mathrm{g})
\end{array}
$$




$\begin{array}{lcl}\text { Isotope } & \text { Specific Power (mW/ } \\ & & \\ { }^{238} \mathrm{Pu} & 567.16 & \pm 0.57 \\ { }^{239} \mathrm{Pu} & 1.9293 \pm 0.0053 \\ 240 \mathrm{Pu} & 7.098 \pm 0.015 \\ 24{ }^{21} \mathrm{Pu} & 3.390 \pm 0.002 \\ 242 \mathrm{Pu} & 0.1146 \pm 0.0003 \\ 24{ }^{2} \mathrm{Am} & 114.23 & \pm 0.16\end{array}$

In general there is a negligible increase in the uncertainty reported in the isotopic mass \% as a result of radioactive decay. This is not always the case for ${ }^{241} \mathrm{Am}$. If ${ }^{241} \mathrm{Am}$ was absent at the time of the original analysis, or only present in minute amounts, then changes in $\sigma\left({ }^{24 i} \mathrm{Am}\right)$ must be considered.

$$
\sigma^{2}\left({ }^{41} \mathrm{An}\right) \cong\left[1.034 t\left(\lambda_{241}-\lambda_{\mathrm{AM}}\right) \cdot \sigma\left({ }^{24 i} \mathrm{Pu}\right)\right]^{2}+\sigma^{2}\left({ }^{241} \mathrm{Am}\right)
$$

The $8080 \mu \mathrm{P}$ code for these calculations is given in Appendix B.

\section{B. Analysis of Sample Power}

\section{Data Acquisition}

The calorimeter feedback circuitry adjusts the power supplied to the inner cylinder coils so that a constant temperature environment for the sample chamber is maintained. (See Fig. 5.) The inner coil $\left(\mathrm{T}_{3}\right)$ voltage and current are alternately monitored by a 12-bit analog-to-digital converter (ADC), which transmits data to the microprocessor at a rate of ten readings/ sec. Software multiplication of each voltage-current pair produces an "instantaneous" $T_{3}$ power. Ten such measurements are averaged to produce a two-second reading which is displayed on the liquid crystai display. The system will then calculate the average power $\left[E\left(P_{i}\right)\right]$ supplied by the calorimeter, and the sample standard deviation $\left[s\left(\mathrm{P}_{1}\right)\right]$ associated with the measurement. Since the microprocessor performs floating-point arithmetic with 5digit software (NOVONICS FP 70B), it is necessary to use the following blasedaverage approach to maintain sufficient accuracy. 


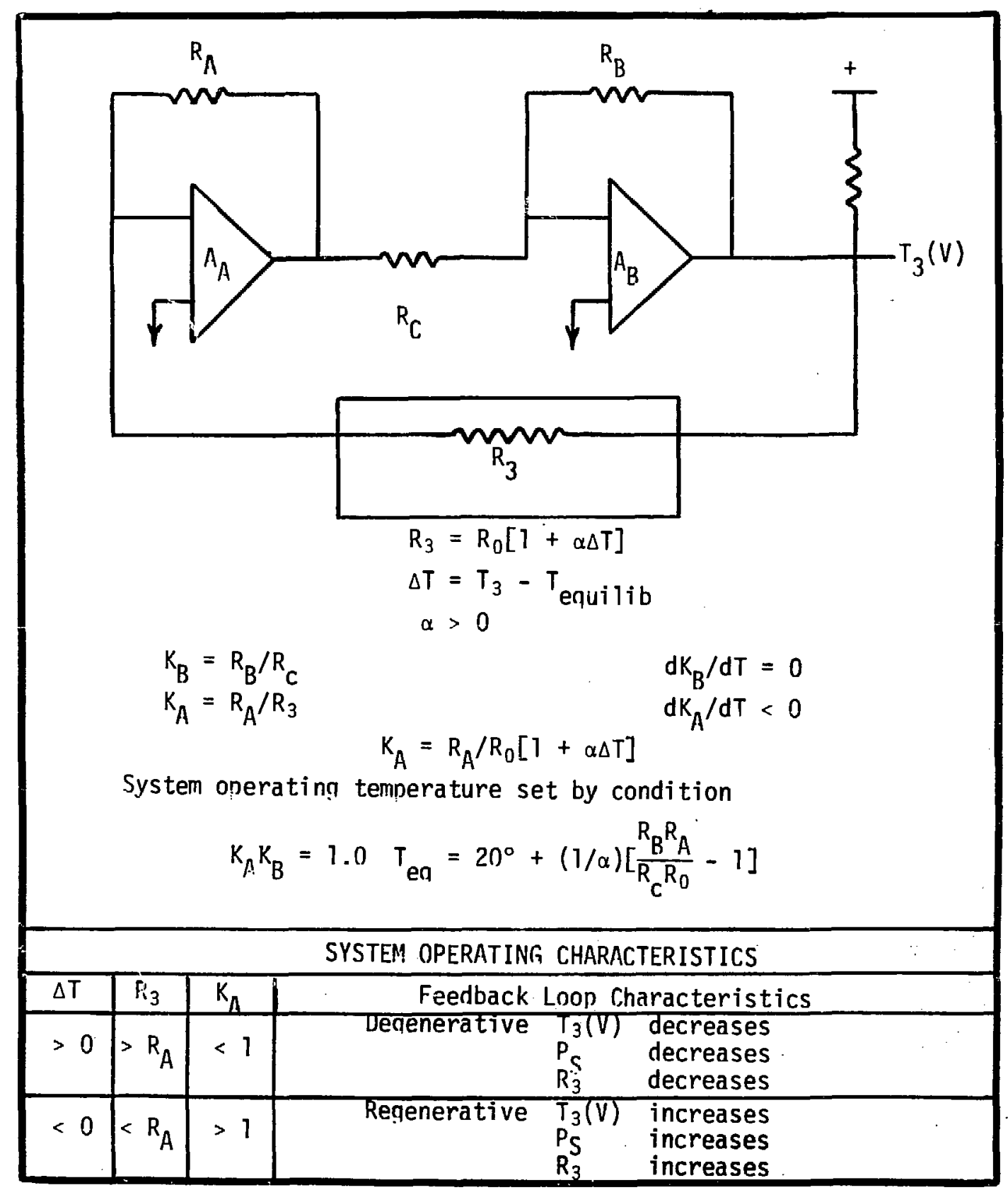

Fig. 5. Resistance thermometry and feedback contro1 circuitry in ANL air-chamber calorimeters. 
DETTA ACNUISITION ROUTINE

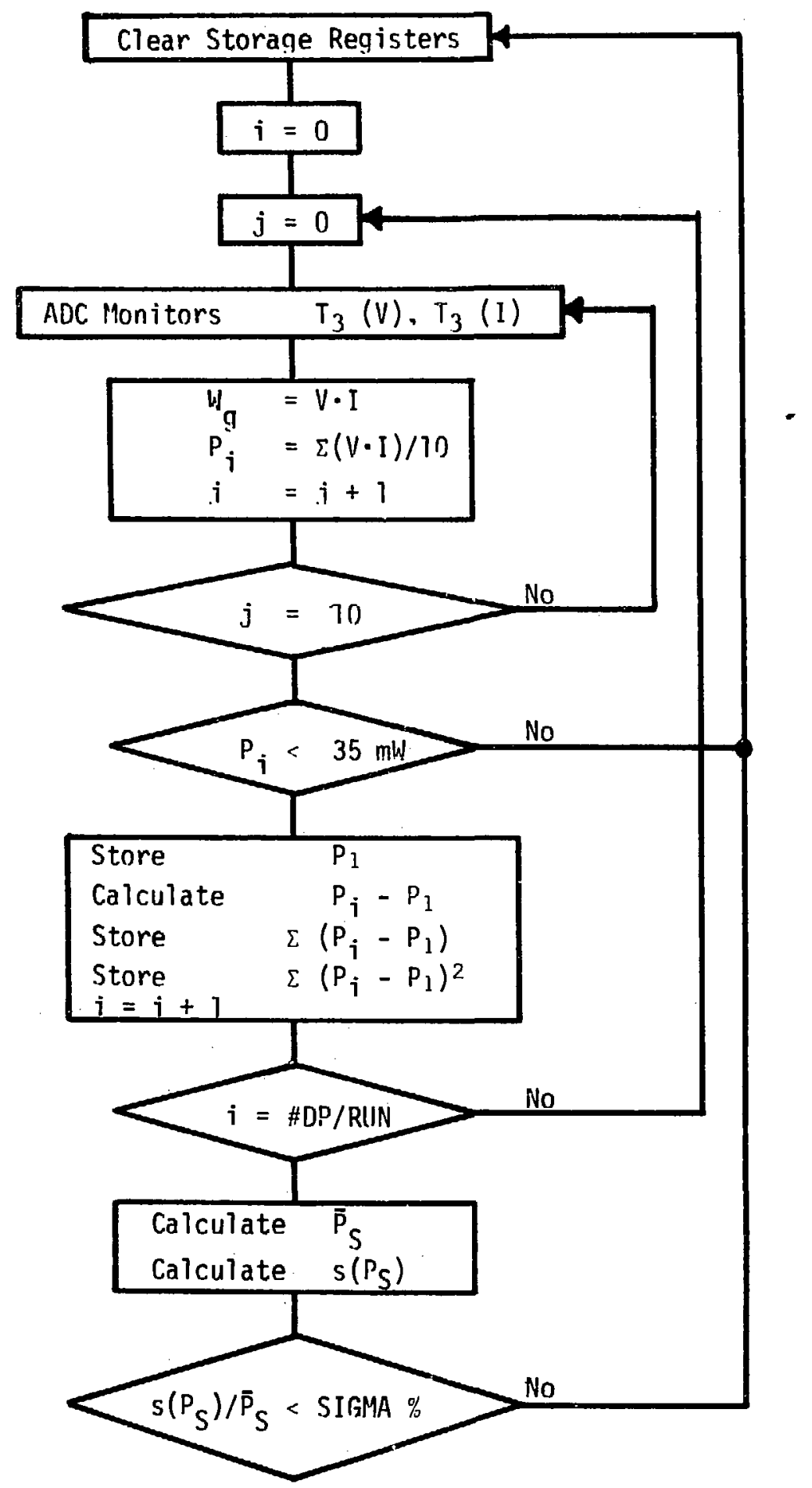

Fig. 6. Data acquisition flowchart. 


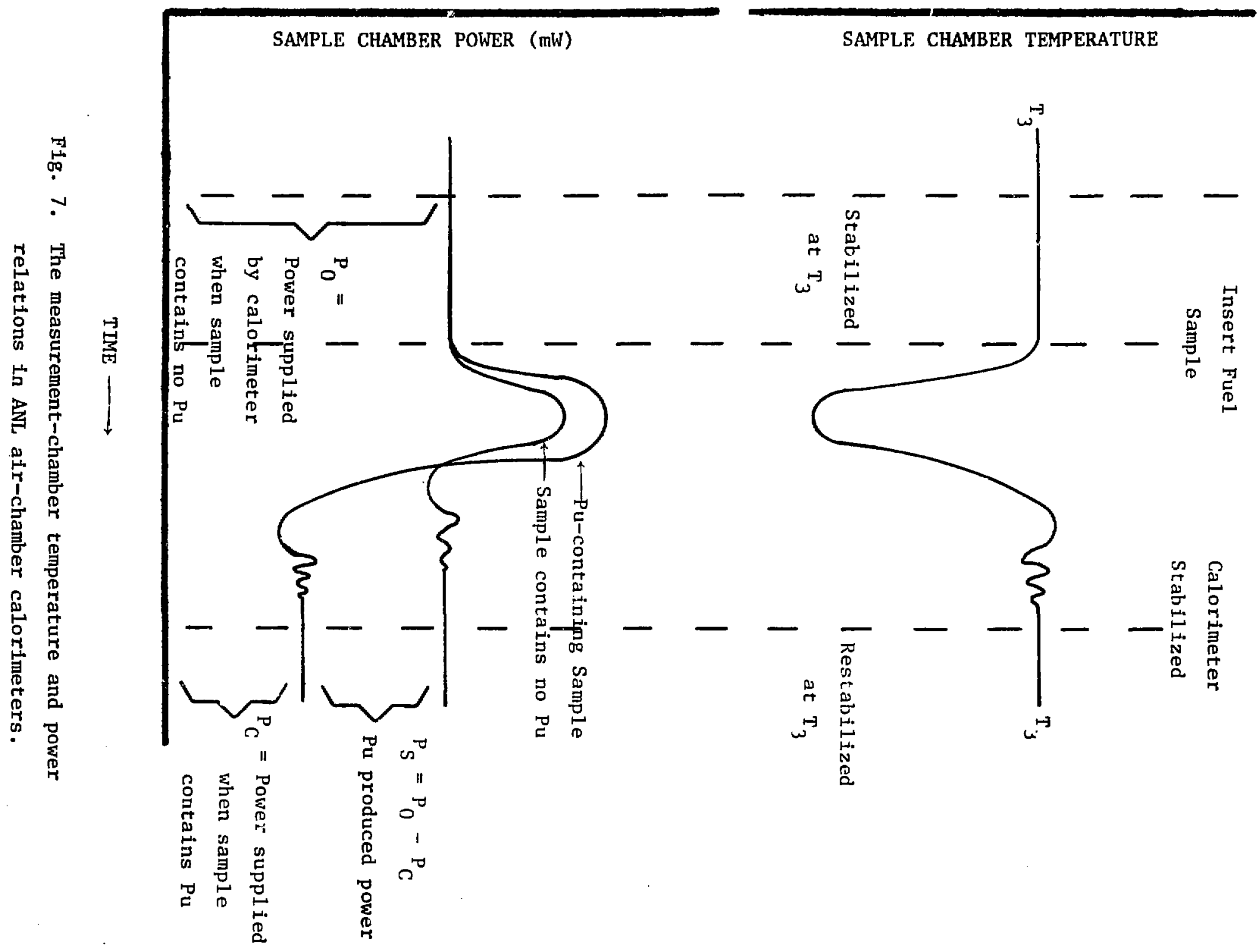


Given a set of power measurements

$$
\mathrm{P}_{1} \quad \mathrm{i}=1, \mathrm{~N}
$$

Define a new set

$$
\hat{\mathrm{P}}_{1} \quad=\left(\mathrm{P}_{\mathrm{i}}-\mathrm{P}_{1}\right) \quad \mathrm{i}=1, \mathrm{~N}
$$

then

$$
\begin{aligned}
E\left(\hat{P}_{i}\right) & =\sum \hat{P}_{i} / N=E\left(P_{i}\right)-P_{i} \\
\therefore E\left(P_{1}\right) & =E\left(\hat{P}_{i}\right)+P_{1}
\end{aligned}
$$

and

$$
\begin{aligned}
\sigma^{2}\left(\hat{P}_{1}\right) & =E\left(\hat{P}_{1}^{2}\right)-\left[E\left(\hat{P}_{1}\right)\right]^{2}=\sigma^{2}\left(P_{1}\right) \\
s^{2}\left(P_{1}\right) & =(N / N-1) \cdot \sigma^{2}(\hat{P}) \\
& \equiv \sum\left[P i-E\left(P_{i}\right)\right]^{2} /(N-1)(N)
\end{aligned}
$$

A flowchart describing the data-acquisition process is given in Fig. 6 .

\section{Analysis of Data}

The inner sample chamber is held at a constant temperature of $45.1^{\circ} \mathrm{C}$ 。 When no heat-producing source is present, the calorimeter supplies a constant power, $P_{0}$, of $32 \mathrm{~mW}$ to maintain this temperature. If a sample containing heat-producing plutonium is placed in the calorimeter, the power which the circuitry must supply to mainizain $45.1^{\circ} \mathrm{C}$ drops to a lower value, $P_{c}$. Consequently, we may determine the power produced by the plutonium, as shown graphically in Fig. 7. Using the effective specific power, $P_{\text {eff }}$ (see Section VI-A), we may determine the plutoniun mass by: 


$$
\mathrm{M}_{\mathrm{PU}}=\overline{\mathrm{P}}_{\mathrm{PU}} / \overline{\mathrm{P}}_{\text {eff }}
$$

where

$$
\begin{aligned}
& \overline{\mathrm{P}}_{\mathrm{Pu}}=\mathrm{F}\left(\overline{\mathrm{P}}_{0}-\overline{\mathrm{P}}_{\mathrm{c}}\right) \\
& \mathrm{F}=\mathrm{Pu} \text { normalization factor }=1.0 \\
& \text { (determined from an electrical calibration } \\
& \text { and } \mathrm{a} \mathrm{Pu} \text { calibration) }
\end{aligned}
$$

The measurement precision is defined by

$$
\frac{\mathrm{s}^{2}(\mathrm{P})}{\overline{\mathrm{P}}^{2}}=\frac{\mathrm{s}^{2}(\mathrm{SYS})}{\overline{\mathrm{P}}_{0}{ }^{2}}+\frac{\mathrm{s}^{2}(\mathrm{STAT})}{\overline{\mathrm{P}}_{\mathbf{c}}{ }^{2}}
$$

where

$$
\begin{aligned}
& \text { s(STAT) is the uncertainty of the mean which is defined as } \\
& \text { (standard deviation) } / \sqrt{N}
\end{aligned}
$$

$\mathbf{s}$ (SYS) is the uncertainty due to systematic imprecision $\simeq 0.08 \%$,

the components of which are

a) system reproducibility error, s(REP)

b) sampie heat distribution error, $s(\mathrm{HDE})$

c) calibration uncertainty, $\mathbf{s}$ (CALIB)

d) thermal interferences, $s$ (TEMP)

$$
\mathrm{s}^{2}\left(\overline{\mathrm{M}}_{\mathrm{Pu}}\right)=\mathrm{M}_{\mathrm{Pu}}{ }^{2}\left[\frac{\mathrm{s}^{2}\left(\overline{\mathrm{P}}_{\mathrm{eff}}\right)}{\overline{\mathrm{P}}_{\mathrm{eff}}{ }^{2}}+\frac{\mathrm{s}^{2}\left(\overline{\mathrm{P}}_{\mathrm{Pu}}\right)}{\overline{\mathrm{P}}_{\mathrm{Pu}}{ }^{2}}\right]
$$

The code for the calculation of the sample mass and uncertainty is included in Appendix B. 
A more rigorous analysis which may be performed of $\hat{\mathrm{f}}-1 \mathrm{ine}$ by the user is presented below.

1) Electrical Ca1ibration

$$
\overline{\mathrm{P}}_{\mathrm{M}}=\mathrm{A}+\mathrm{B} \cdot \overline{\mathrm{P}}_{\mathrm{A}}
$$

where

$$
\begin{aligned}
& \overline{\mathrm{P}}_{\mathrm{M}}=\text { measured power }=\frac{\sum \mathrm{P}_{\mathrm{M}_{i}} / \mathbf{s}_{\mathbf{i}}{ }^{2}}{\sum 1 / \mathbf{s}_{\mathbf{i}}{ }^{2}} \\
& \overline{\mathrm{P}}_{\mathrm{A}}=\text { applied power }=\frac{\sum \mathrm{P}_{\mathrm{A}_{i}} / \mathbf{s}_{\mathbf{i}}{ }^{2}}{\sum 1 / \mathrm{s}_{\mathbf{i}}{ }^{2}}
\end{aligned}
$$

$s_{i}=$ uncertainty in the mean of $\mathrm{P}_{\mathrm{M}_{i}}$ (statistica1)

The sample statistical uncertainty is defined as

$$
\mathrm{s}^{2}(\overline{\mathrm{P}})=\sum\left[\mathrm{P}_{\mathbf{i}}-\mathrm{E}\left(\mathrm{P}_{\mathbf{i}}\right)\right] / \mathrm{n}(\mathrm{n}-1)
$$

which is

$$
s^{2}(\bar{P})=s^{2}\left(P_{i}\right) / n
$$

This is the uncertainty in the mean of the power distribution, rather than the uncertainty in a single measurement $\left[s\left(P_{1}\right)\right]$.

$$
B=\frac{\sum\left(\mathrm{P}_{A_{i}} / s_{i}-\bar{P}_{A_{i}} / s_{i}\right)\left(P_{M_{i}} / s_{i}-\bar{P}_{M} / s_{i}\right)}{\sum\left(P_{A_{i}} / s_{i}-\bar{P}_{A} / s_{i}\right)^{2}}
$$




$$
\mathrm{A}=\overline{\mathrm{P}}_{\mathrm{M}}-\mathrm{BP}_{\mathrm{A}}
$$

2) Sample Power

$$
\overline{\mathrm{P}}_{\mathrm{S}}=\left(\overline{\mathrm{P}}_{\mathrm{M}}-\mathrm{A}\right) / \mathrm{B}
$$

relating the power $\left(\mathrm{P}_{A}\right)$ actually measured to the source-produced power $\left(\mathrm{P}_{M}{ }_{\mathrm{M}}\right)$

$$
s^{2}\left(P_{A}\right)=\left(\frac{\partial P_{A}}{\partial P_{M}}\right)^{2} s^{2}\left(P_{M}\right)+\Sigma\left(\frac{\partial P_{A}}{\partial P_{i}}\right)^{2} s^{2}\left(P_{i}\right)
$$

where

$$
\begin{aligned}
& \mathrm{P}_{i} \quad \equiv \text { measured calibration observations } \\
& \mathrm{s}^{2}\left(\mathrm{P}_{\mathrm{M}}\right) \quad \equiv \quad \text { includes statistical and all other sources of error }
\end{aligned}
$$

$$
\left(\underset{\partial P_{i}}{\left.\stackrel{\partial P_{A}}{(}\right)}=\frac{\partial\left[\left(P_{M}-A\right) \cdot B^{-1}\right]}{\partial P_{i}}=-\left(\frac{P_{S}}{B} \times \frac{\partial B}{\partial P_{i}}+\frac{1}{B} \times \frac{\partial A}{\partial P_{i}}\right)\right.
$$

$\therefore \quad \sum\left(\frac{\partial \mathrm{P}_{\mathrm{A}}}{\partial \mathrm{P}_{i}}\right)^{2} \mathrm{~s}^{2}\left(\mathrm{P}_{i}\right)=\Sigma \frac{\mathrm{s}^{2}\left(\mathrm{P}_{i}\right)}{\mathrm{B}^{2}}\left[\frac{1}{\mathrm{n}}+\frac{\left(\mathrm{P}_{\mathrm{S}}-\bar{\mu}\right)^{2}}{q \mu^{2}}\right]$

where $\vec{\mu}=\left(\mathrm{Yn}_{\mathrm{n}}\right)\left(\Sigma \mathrm{P}_{1}\right)$

$$
q \mu^{2}=\Sigma\left(P_{i}-\mu\right)^{2}
$$

and

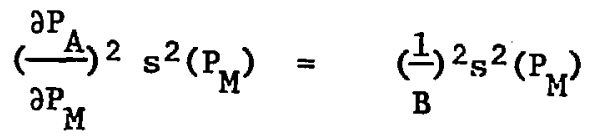


3) Source Normalization

$$
\mathrm{K}_{\mathrm{Pu}}=\left(\mathrm{W}_{238} / \mathrm{P}_{238}\right) \cdot \mathrm{P}_{\mathrm{A}}
$$

where

$$
\begin{aligned}
& \mathrm{W}_{238} \begin{array}{l}
\text { represents the actual power output of a } \\
\text { calfbrated }{ }^{238} \mathrm{Pu} \text { source }
\end{array} \\
& \mathrm{P}_{238} \begin{array}{l}
\text { represents the calorimeter-determined output of } \\
\text { the calibrated source }
\end{array}
\end{aligned}
$$

4) Sample Mass

Thus, by combining the above

$$
\overline{\mathrm{M}}_{\mathrm{Pu}}=\mathrm{K}_{\mathrm{Pu}}\left(\overline{\mathrm{P}}_{\mathrm{M}}-\mathrm{A}\right) / \mathrm{BP} \mathrm{eff}_{\text {ff }}
$$

and the uncertainty is obtained from

$$
s^{2}(\mathrm{M})=s^{2}\left(\overline{\mathrm{P}}_{\mathrm{Pu}}\right)+s^{2}\left(\mathrm{P}_{\mathrm{eff}}\right)
$$

where

$$
\begin{aligned}
\frac{\mathrm{s}^{2}\left(\overline{\mathrm{P}}_{\mathrm{Pu}}\right)}{\widehat{\mathrm{P}}_{\mathrm{Pu}}{ }^{2}}= & \frac{\mathrm{s}^{2}(\mathrm{HDE})}{\overline{\mathrm{P}}_{0}^{2}}+\frac{\mathrm{s}^{2}(\mathrm{REP})}{\overline{\mathrm{P}}_{0}{ }^{2}}+\frac{\mathrm{s}^{2}(\mathrm{CALIB})}{\overline{\mathrm{P}}^{2}} \\
& +\frac{\mathrm{s}^{2}\left(\overline{\mathrm{P}}_{\mathrm{M}}\right)}{\overline{\mathrm{P}}_{\mathrm{M}}{ }^{2}}+\frac{\mathrm{s}^{2}(\mathrm{TEMP})}{\overline{\mathrm{P}}_{0}{ }^{2}}
\end{aligned}
$$


5) System Baseline Check

During multiple sample analysis, the system baseline should be checked periodically by using the relation

$$
t=\left|\bar{P}_{0}-A\right| /\left[s^{2}\left(P_{0}\right)+s^{2}(A)\right]^{\frac{3}{2}}
$$

where

$\overline{\mathrm{P}}_{0}$ is the current calorimeter-supplied power to an empty chamber.

If

$t>1.95$

then a baseline shift must be assumed to have occurred, and a correction should be made to the z ero-power intercept (A). 
APPENDIX A

CALORIMETRIC UNIT CIRCUIT DIAGRAMS $\# 1-12$

IAEA Sma11-Sample Calorimeter:

1. Power distribution

2. Htr - thermistor interface

3. Preheater control

4. TA contro1

5. To contro1

6. $\mathrm{T}_{1}$ control

7. $\mathrm{T}_{2}$ control

8. T3 control

9. T3 contro1 notes

10. Temperature readout

11. Diagnostic Interface

12. Test point truth table 


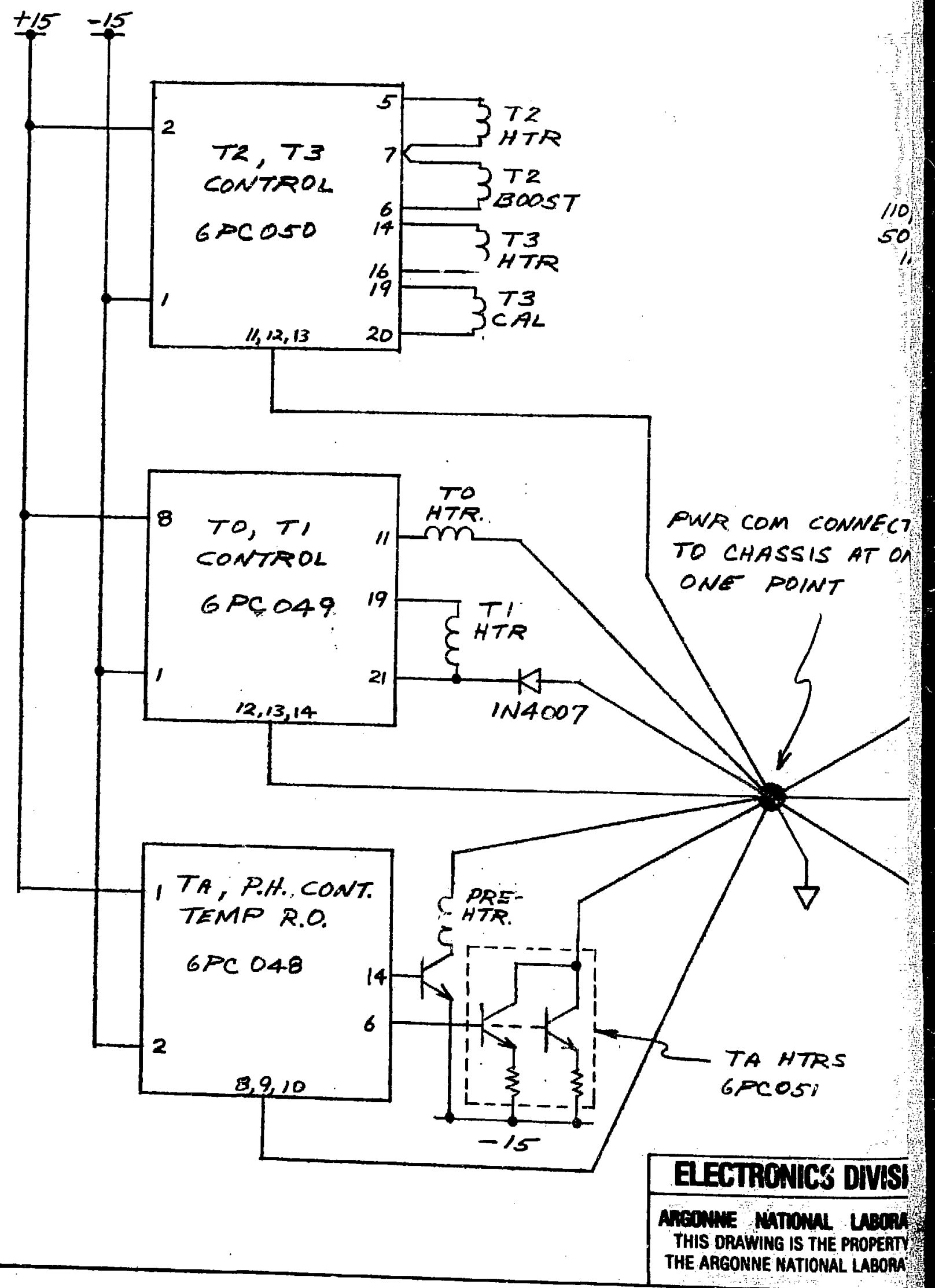




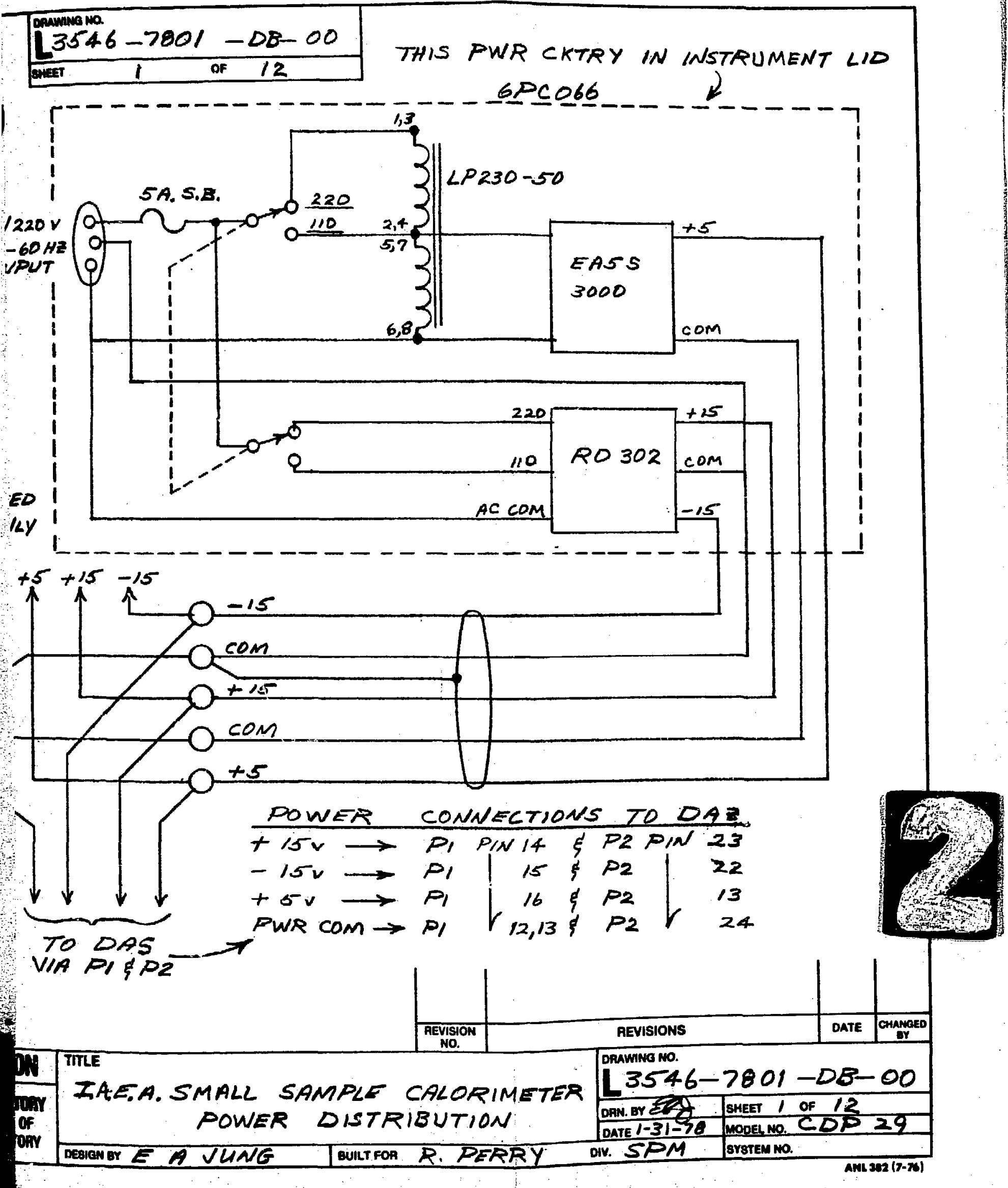




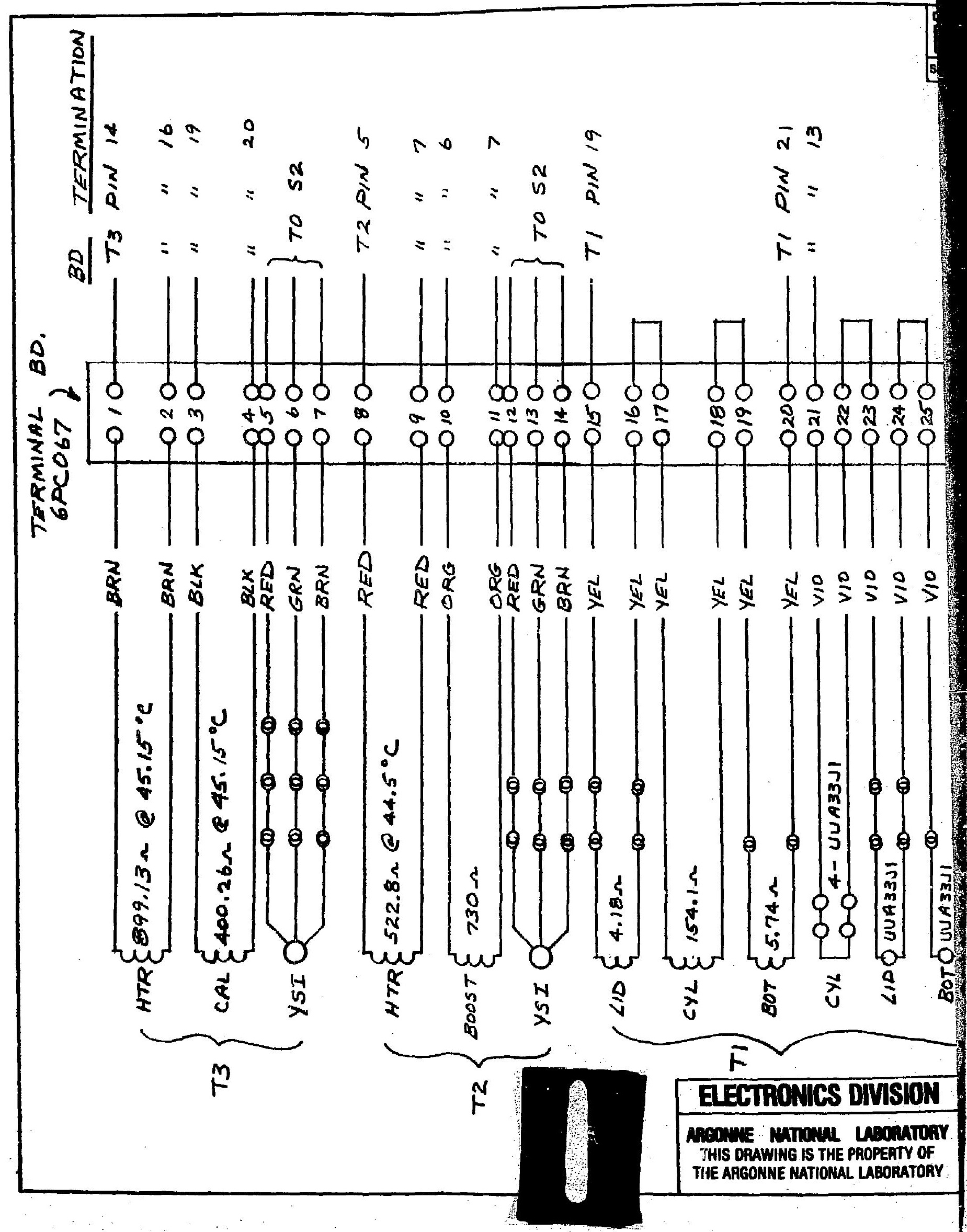


aumina no.

$[3546-7801-D B-00$

$\begin{array}{lll}2 & 2\end{array}$

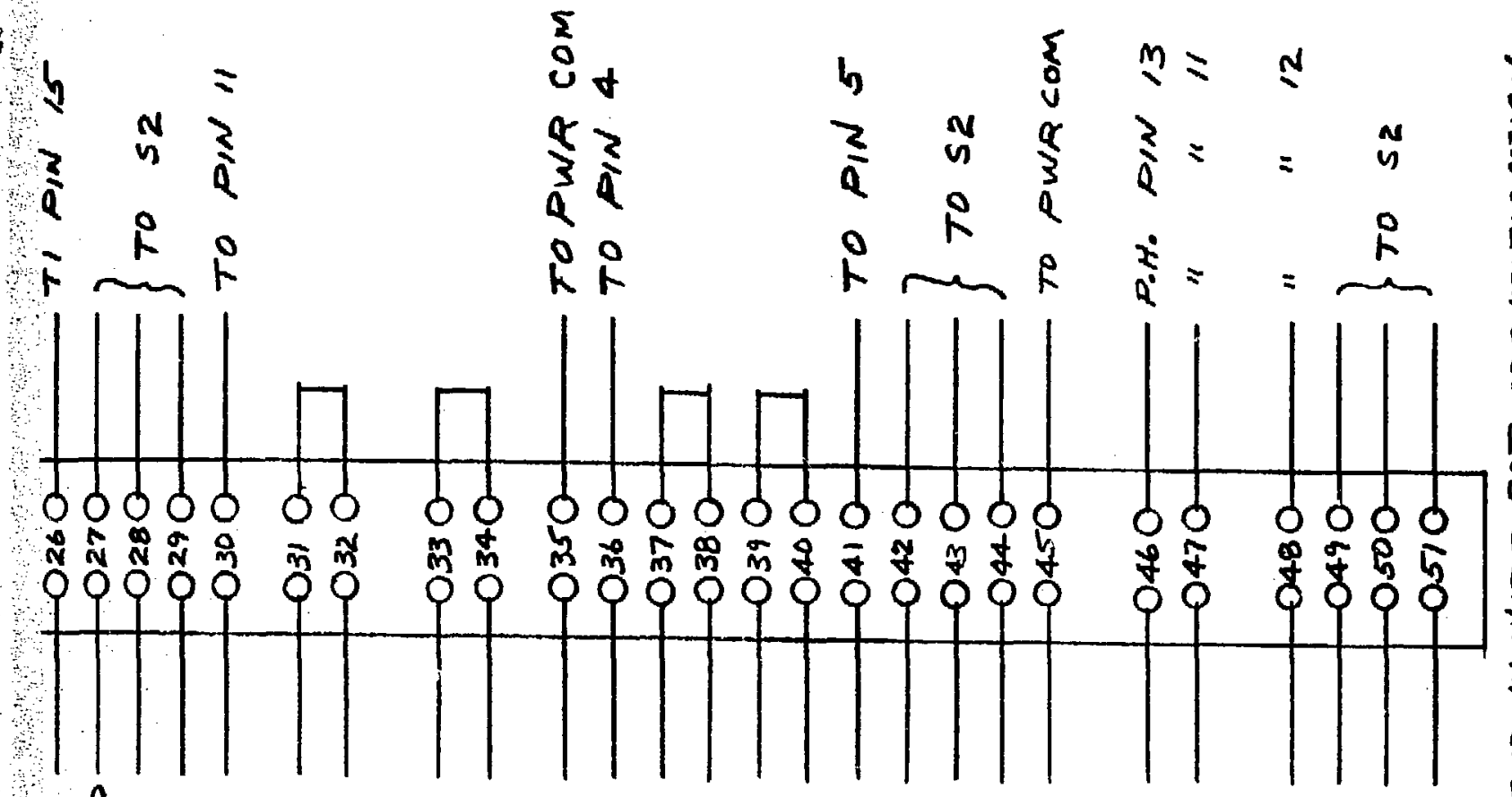

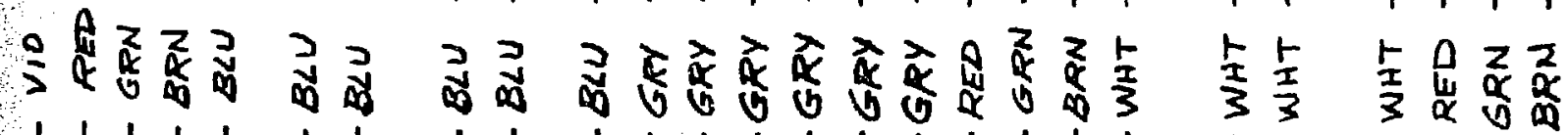

$\sum_{2}^{2}$

4

2

4

$\alpha$

4

4

$\frac{\alpha}{3}$

$\geq 0$

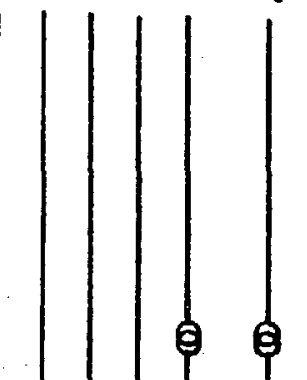

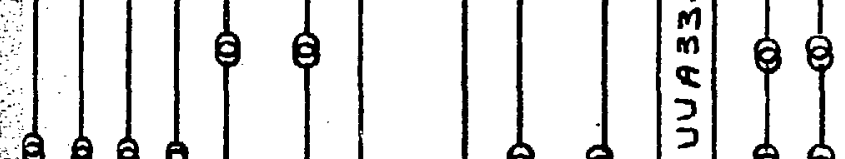

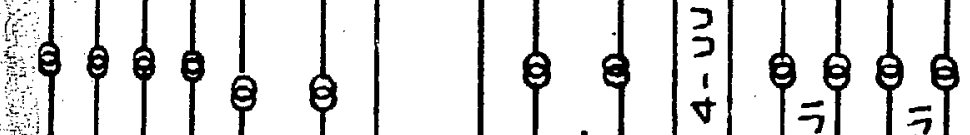

(5)

.

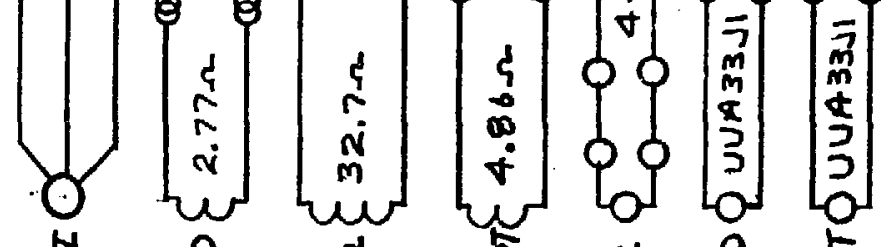

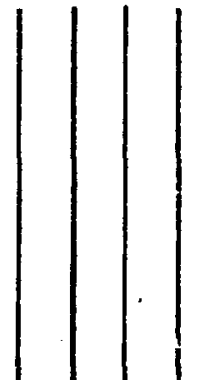




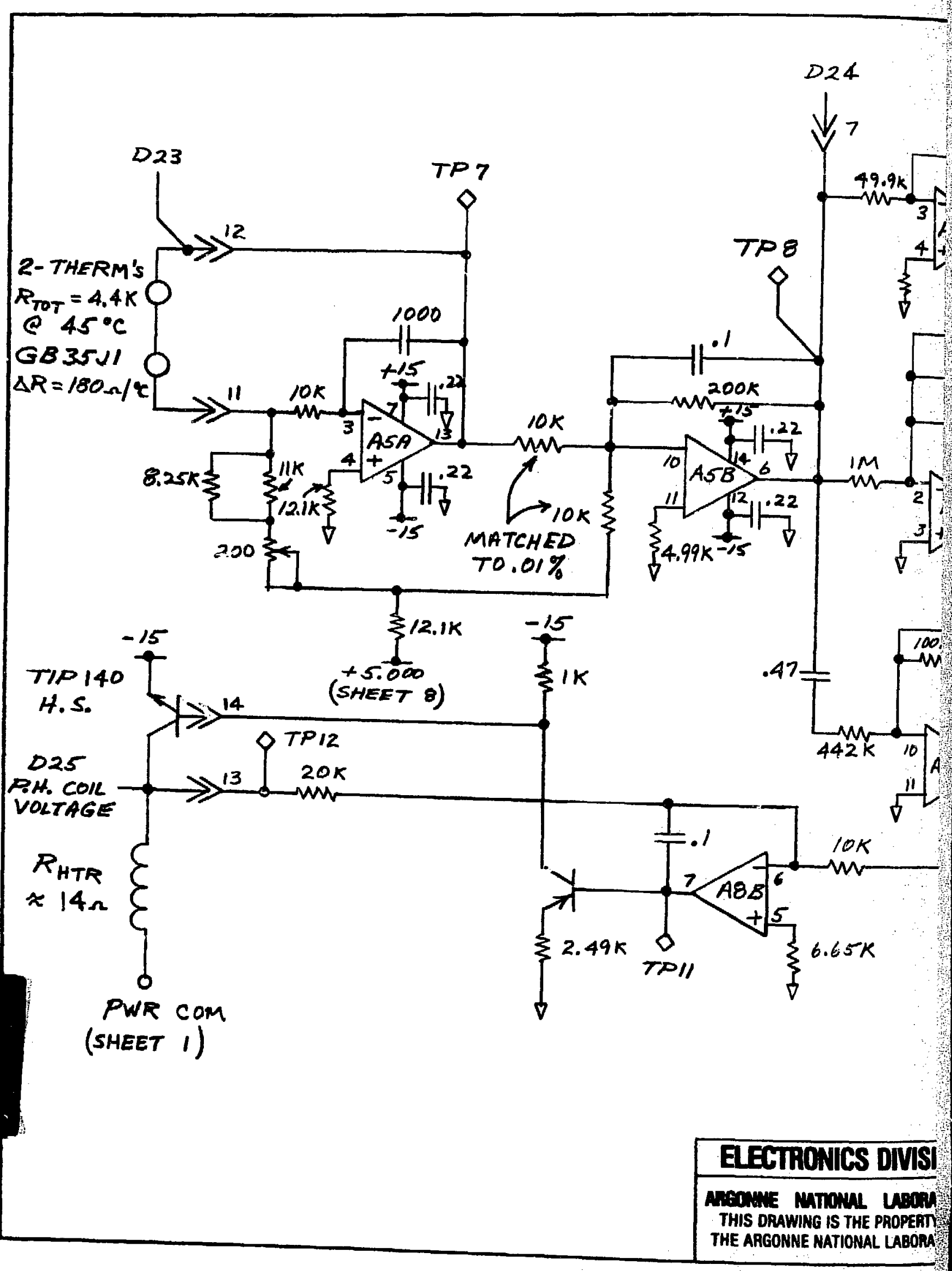




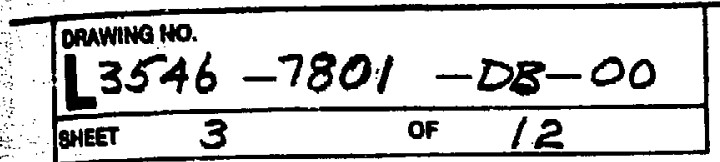

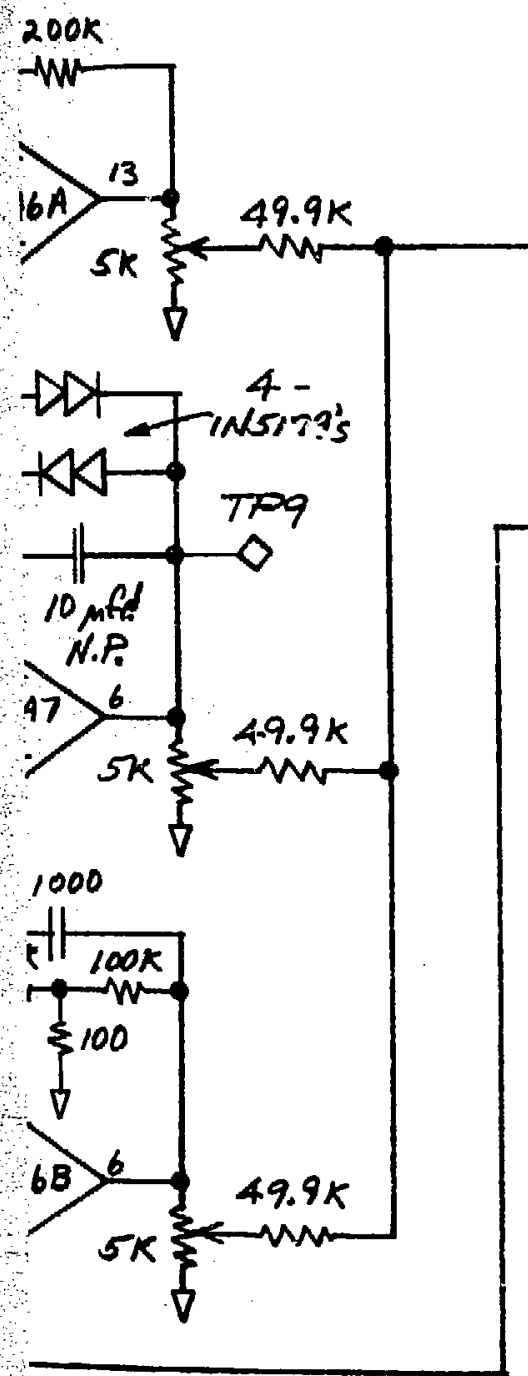

\section{NOTES -}

1 - A5 F AG ARE OPIOCY WITH PINS 5\$12 TO H/5V,

2-A7 IS AD $506 K H$ WITH PIN 7 TO +15, 4 TO-15V.

3 - A8 IS RC4558DN WITH PIN 8 TO +15, 4 TO-15V.

4- ALL RESISTORS ARE METAL FILM.

5- THIS CKT PART OF 6 PCO 48 WITH RED IDENTIFIER MARK. REST ON SHEET $4 \xi 10$

6- FOR " $\Delta$ ", "\" "Dx" NOTATIONS, SEE NOTES b 2 \& 3 , SHEET 8.

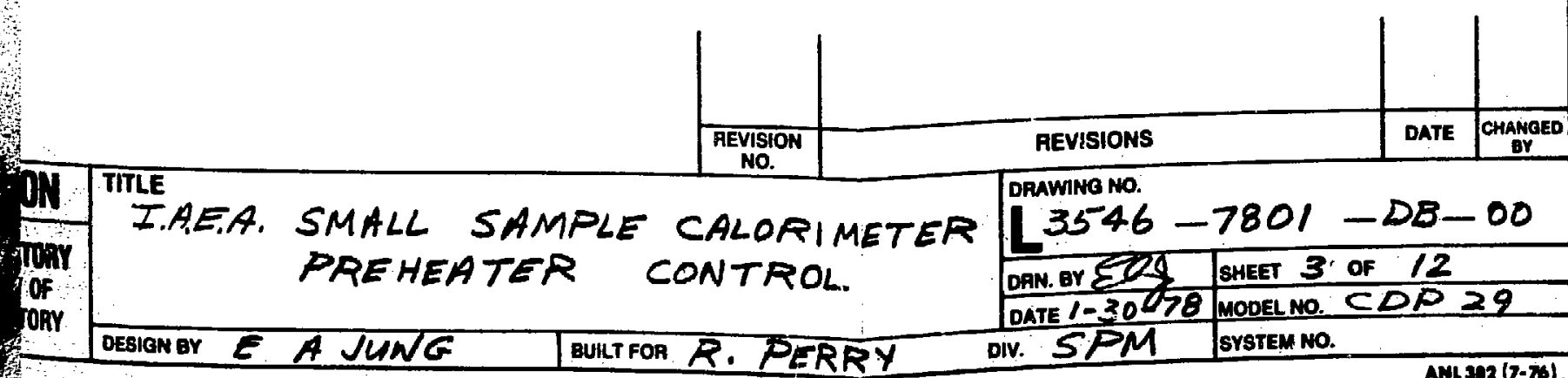




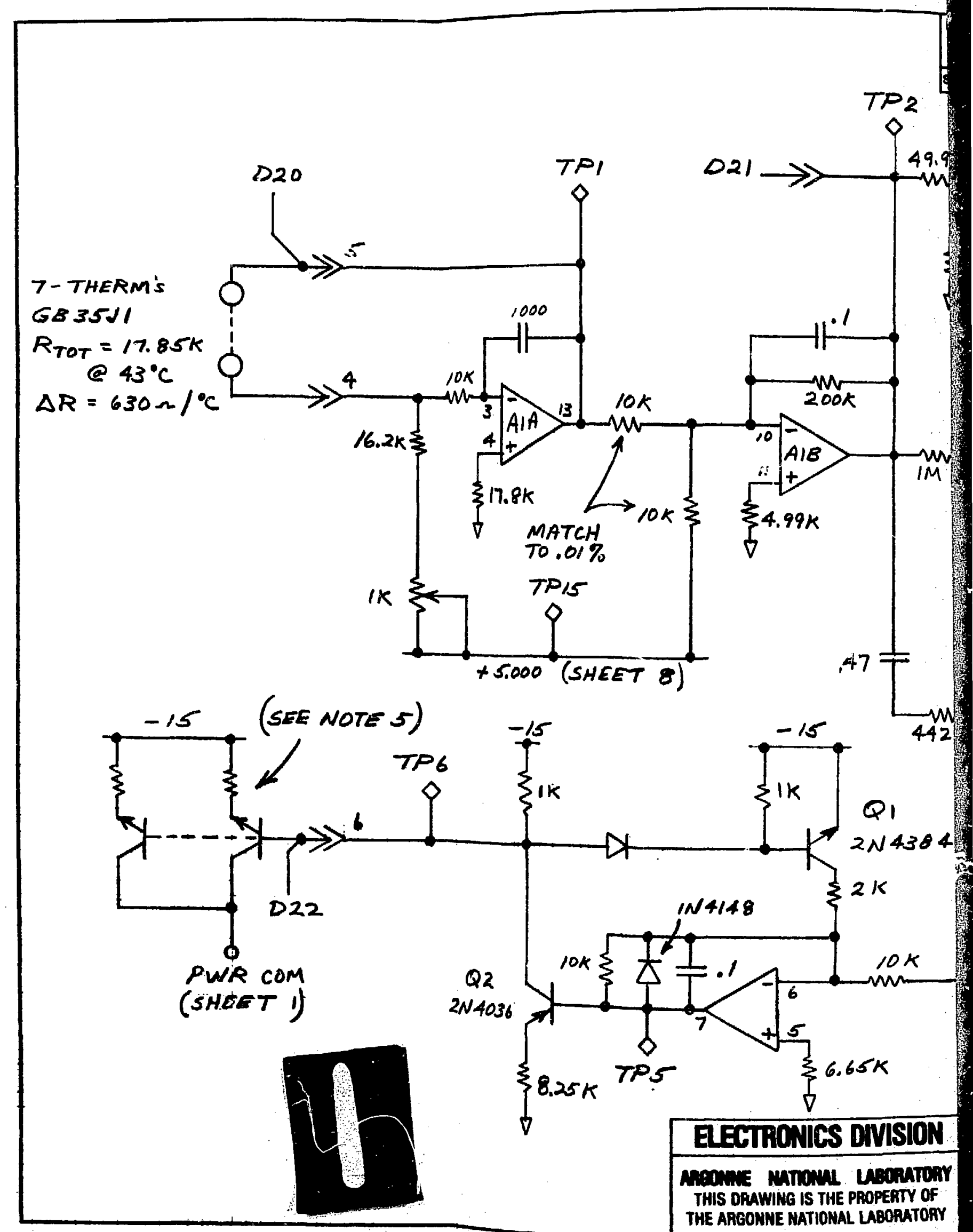


38

$$
\begin{aligned}
& 3546-7801-D B-00 \\
& 4 \text { of } 12
\end{aligned}
$$

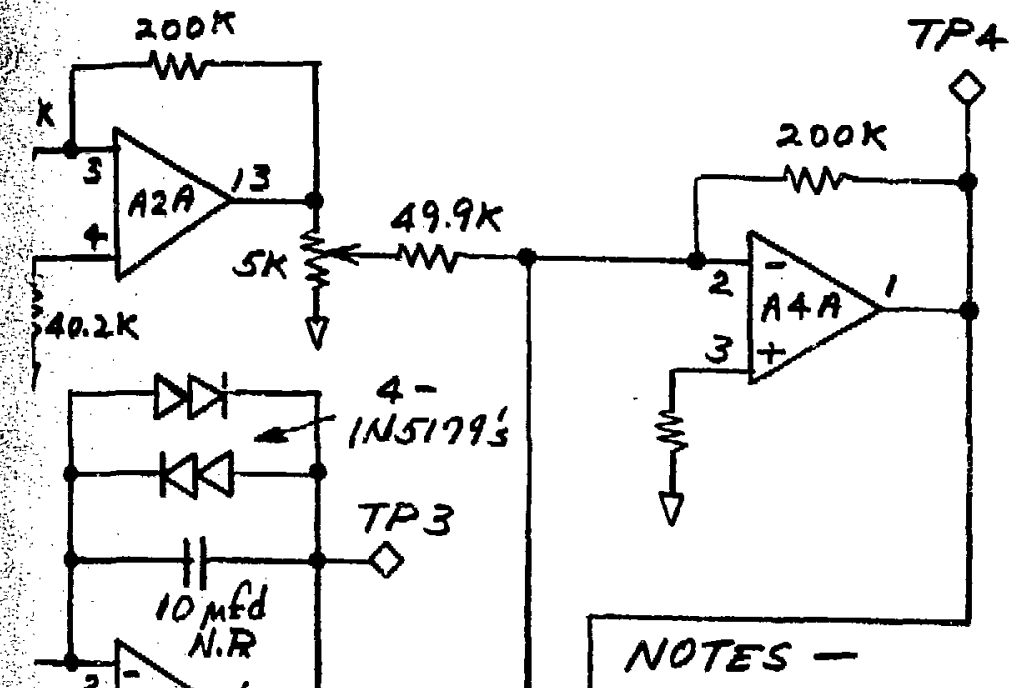

1- AI I A2 ARE OPIOCY W/TH PIN $5 \xi / 270+15$ $7 \% 1470-15$.

2-A3 IS ADSO6 WITH PIN $770+15,4$ T0-15.

3-A4 IS RCA 558DN WITH PIN 8 TO +15,4 T0-15.

4- ALL RESISTORS $1 / 4$ WATT METAL FILM, U. OS.

5 - 14 TRANSISTORS, TIPI4O IN PARALLEL WITH 8.2, $1 / 2 W$ IN EACH EMITTER LEG.

6 - THIS CRT PART OF GPCO48 WITH RED IDENTIFIER MARK, REST ON SHEET $3 \& 10$.

7 - FOR " $\triangle$ ", "\", " $D_{x}$ " NOTATIONS, SEE NOTES $1,2,33$, SHEET 8.
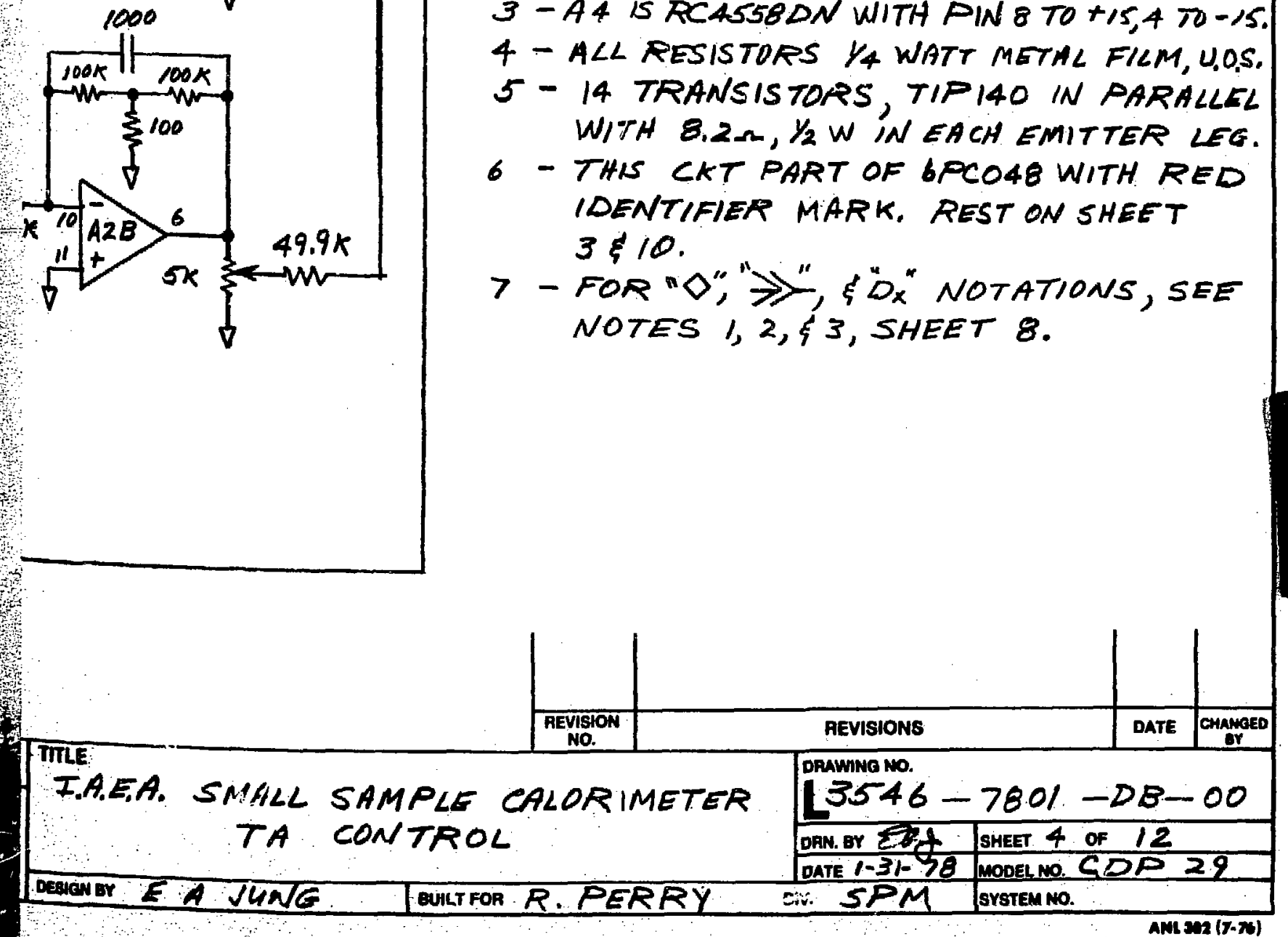


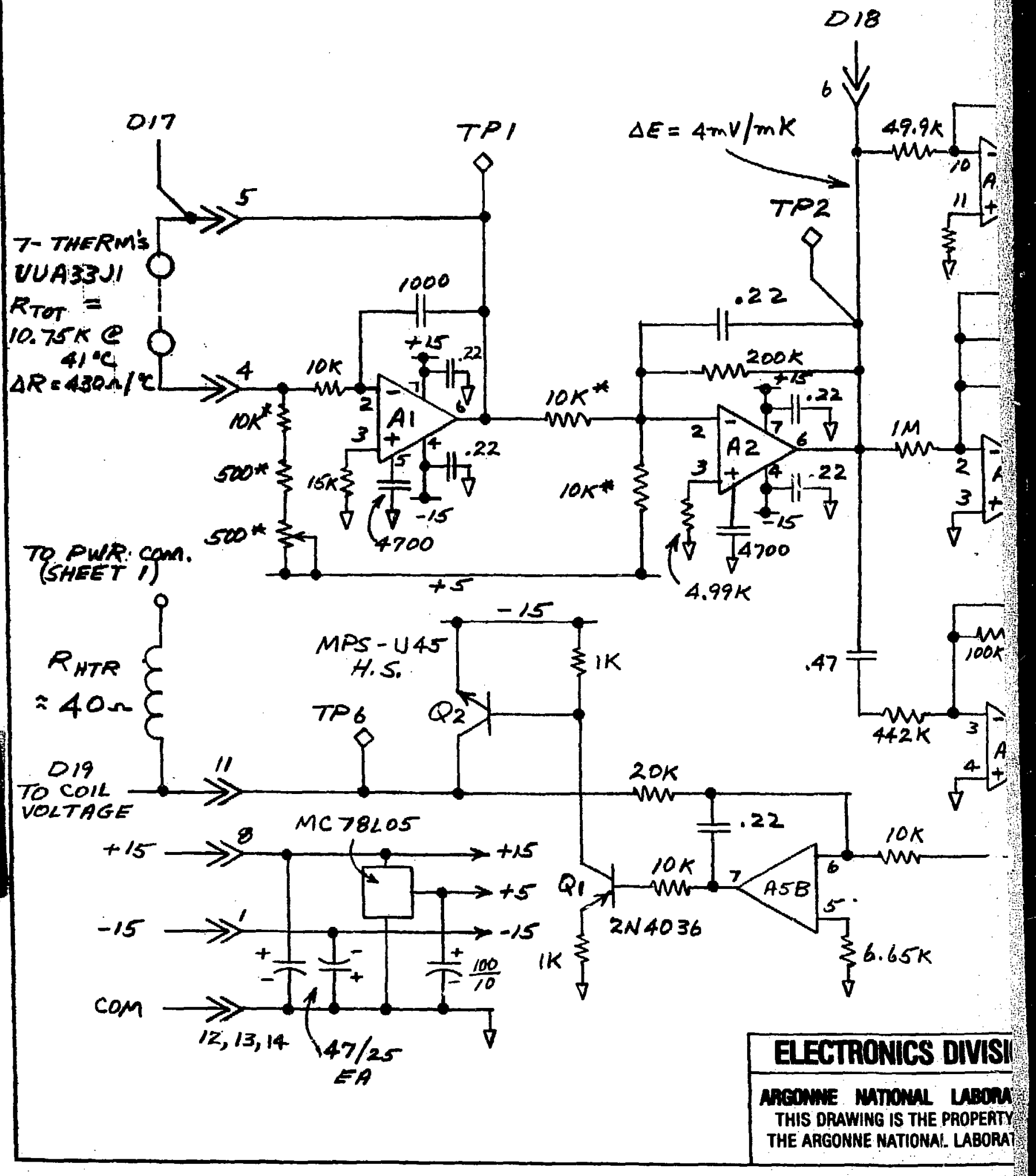


39

OANWING no.

$$
\frac{55-16-7601-08-00}{5}
$$

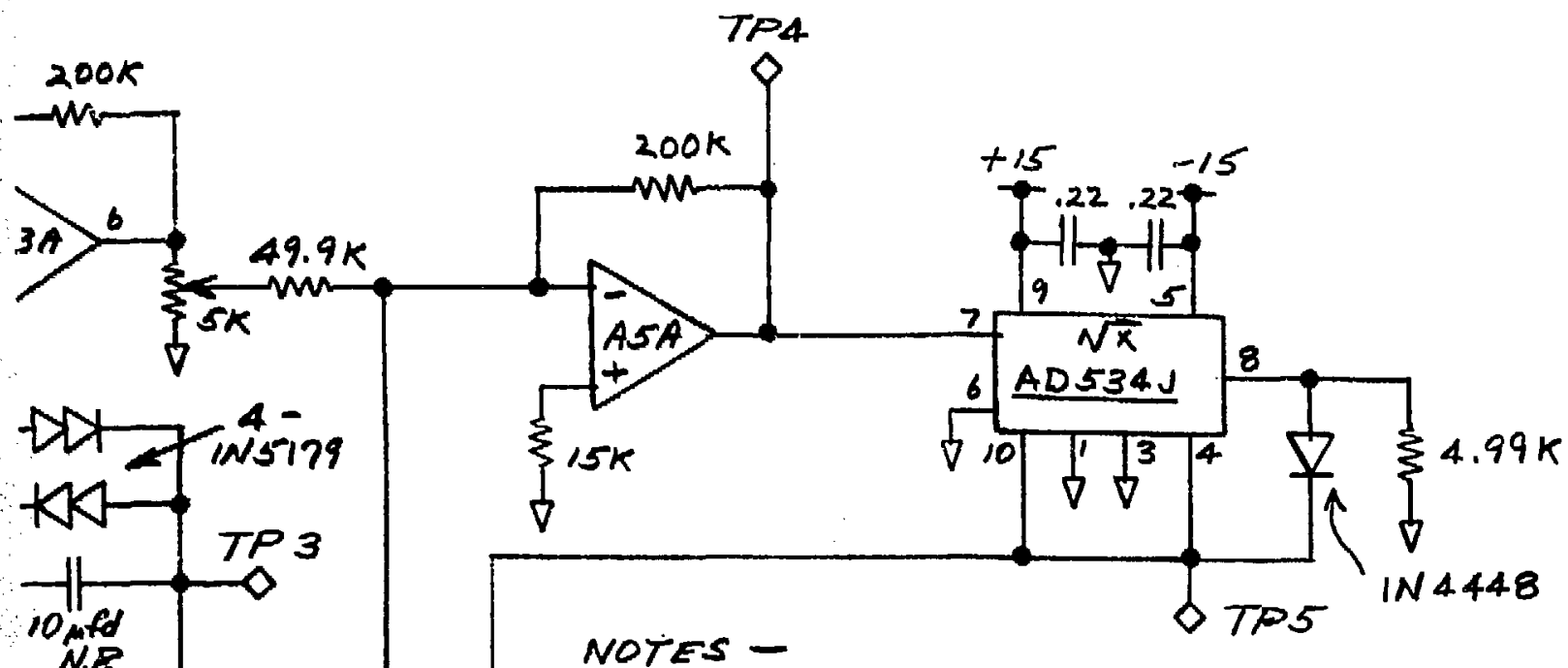

NOTES -

1- AI GA2 ARE B.B. $3510 \mathrm{CM}$

2- A3 IS OPIOCY WITH OINS $5 / 12$ TO + 15

$$
7 \$ 14 \text { TO }-15
$$

3- A4 IS AD 506 :IITH PIN 7 TO +15v, 4 TO -15V.

4- A5 IS RC 4558DN WITH PIN 8 TO +15, 4 T0-15 5 - ALL RESISTORS ARE METAL FILM, U.0.5.

6 - all Resistors \& pots marked "* hae VISHAY SID L I2IOWI RESPECTIVELY.

7 - THIS CAT PART OF GPCO49 WITH BLUE IDENTIFIER MARK. REST ON SHEET 6.

8 - FOR " $\checkmark$ ", "\" $\$$ " "Dx" NOTATIOAS, SEE NOTES 1, 253, SHEET 8.

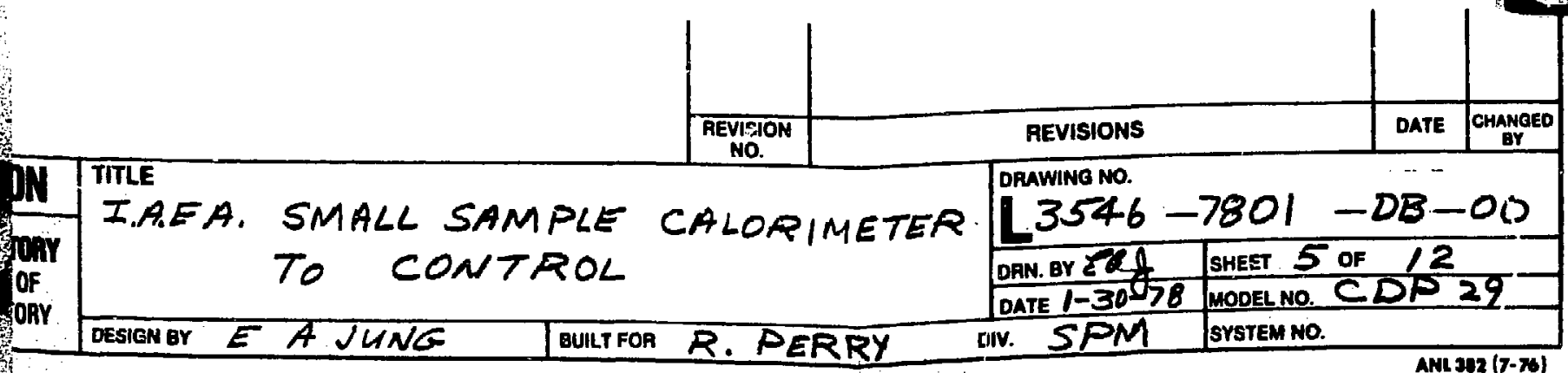




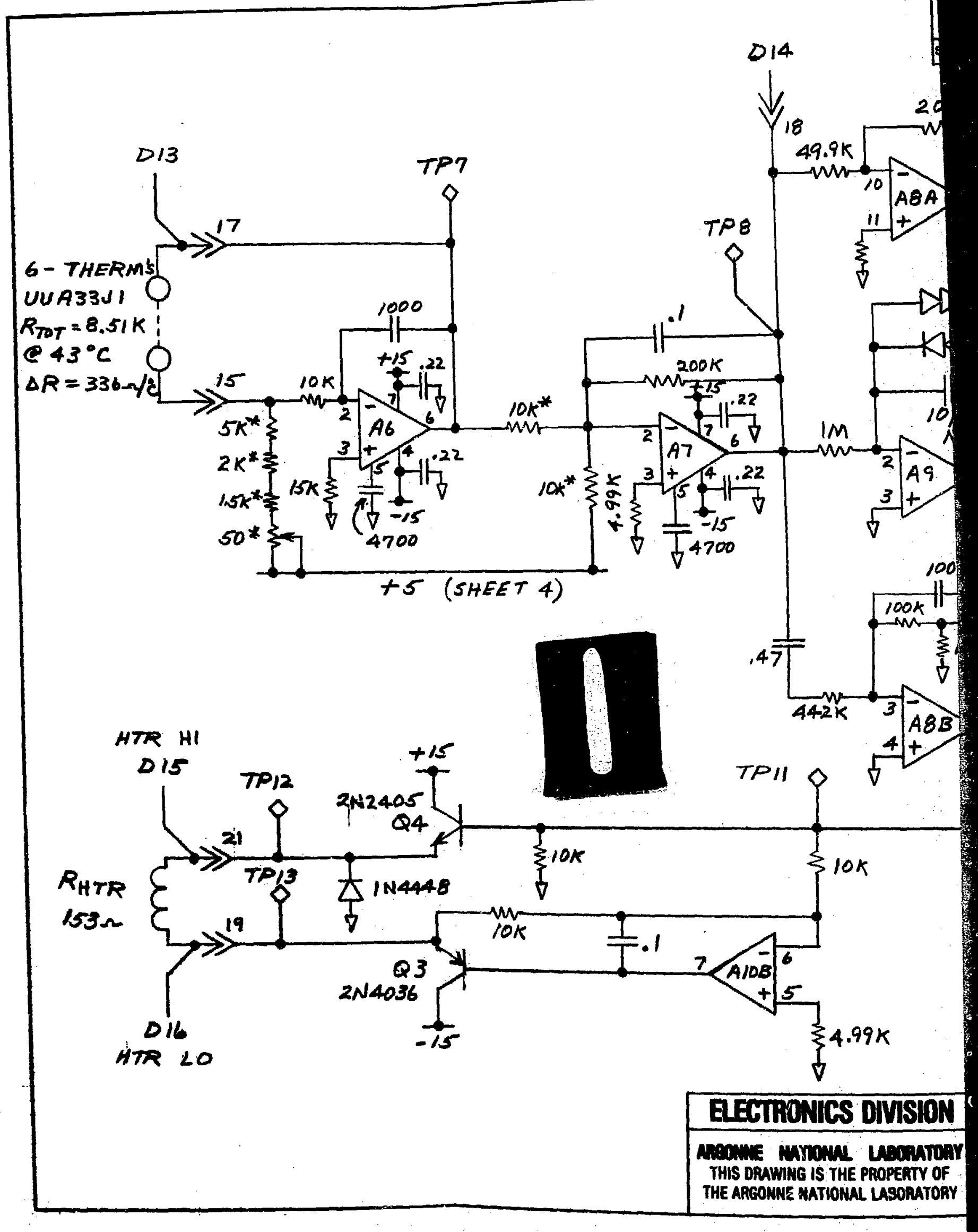


40

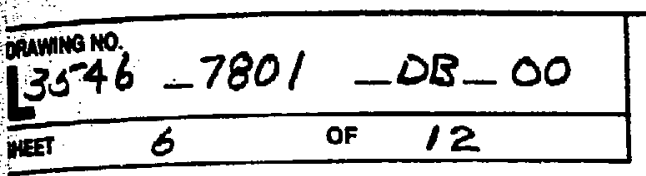

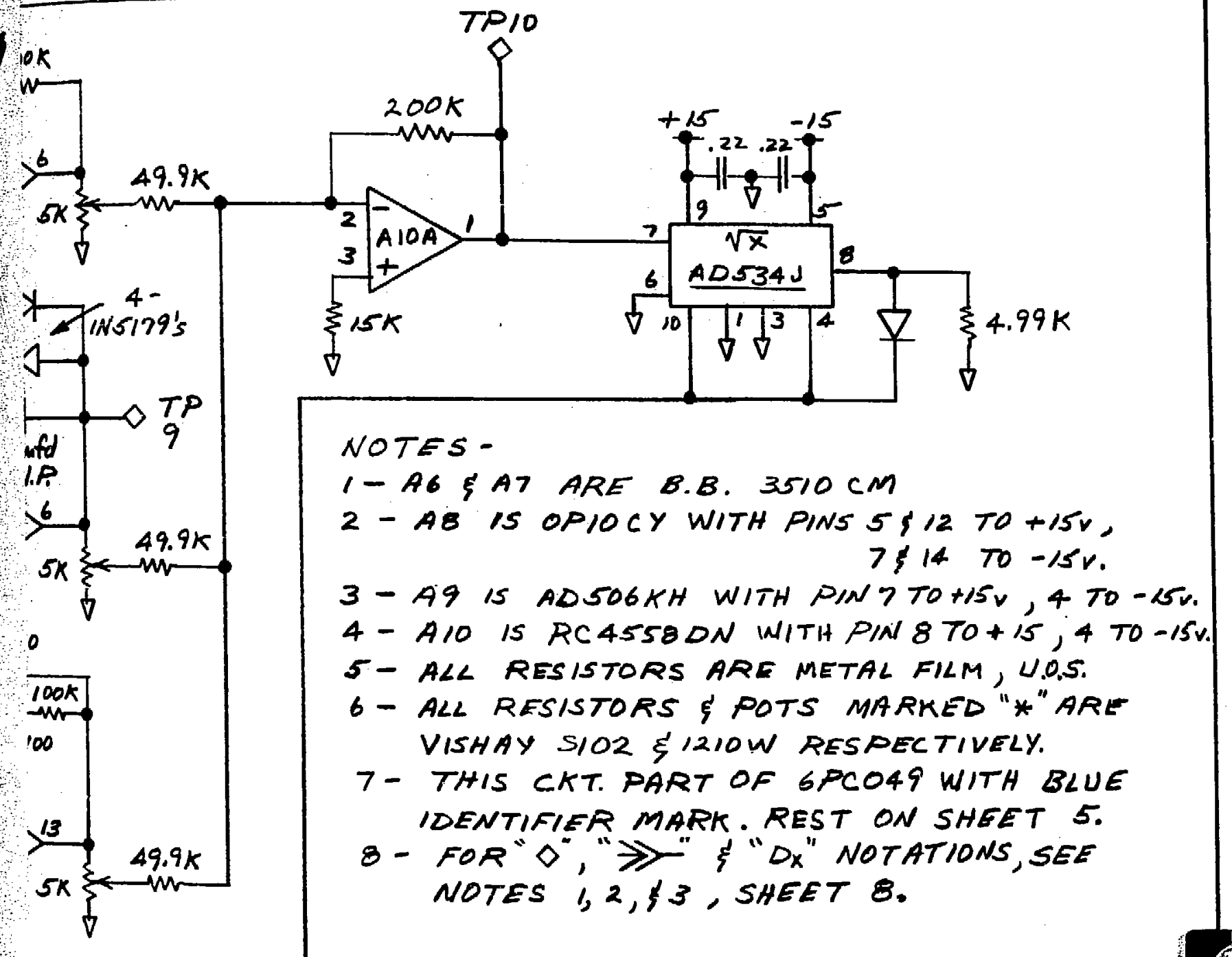

1- A6 \& A7 ARE B.B. $3510 \mathrm{cM}$

2 - AB IS OPIOCY WITH PINS 5 \& 12 TO + $15 \mathrm{~V}$,

3-A9 IS AD 506KH WITH PIN 7 TO +15V, 4 TO -15V.

4 - AID IS RC 4558DN INIT PIN $870+15,4$ TO -15V.

5 - ALL RESISTORS ARE METAL FILM, U.0.5. VISHAY STOL EI2IOW RESPECTIVELY.

7- THIS CKT. PART OF GPCO49 WITH BLUE IDENTIFIER MARK. REST ON SHEET 5. NOTES $1,2,13$, SHEET 8 .

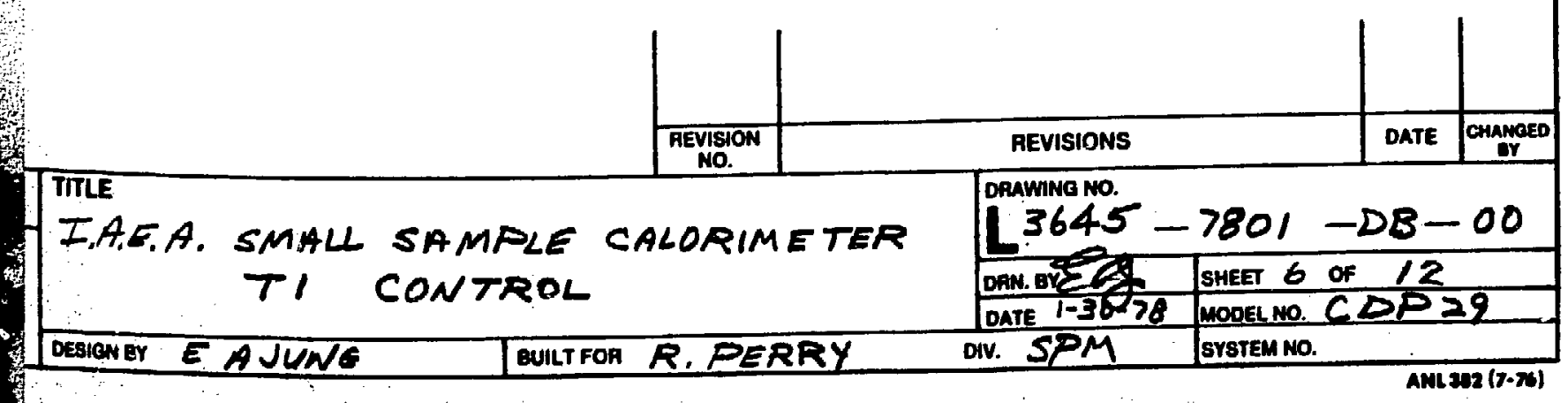




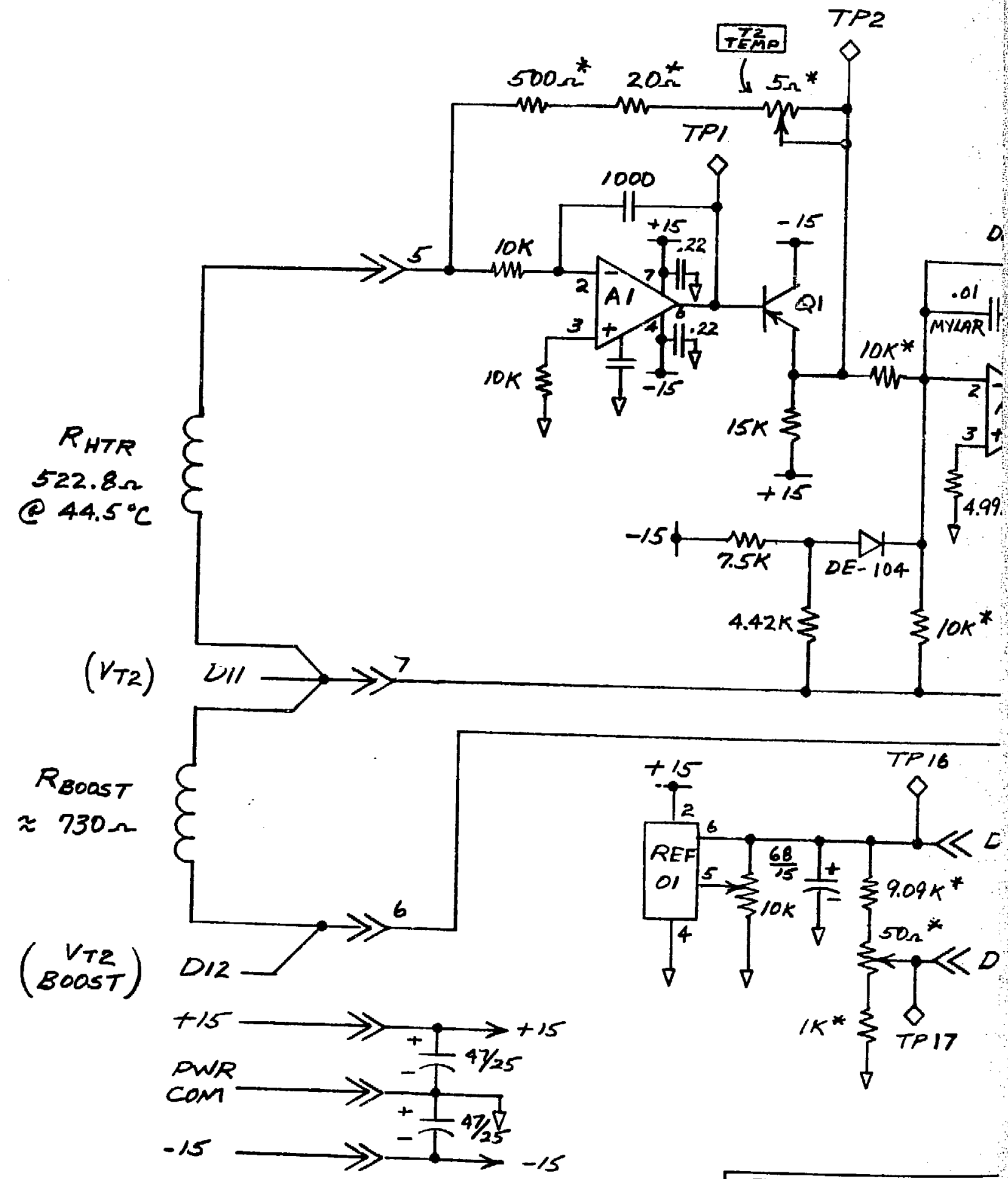

ELECTRONICS DIVISI 
41

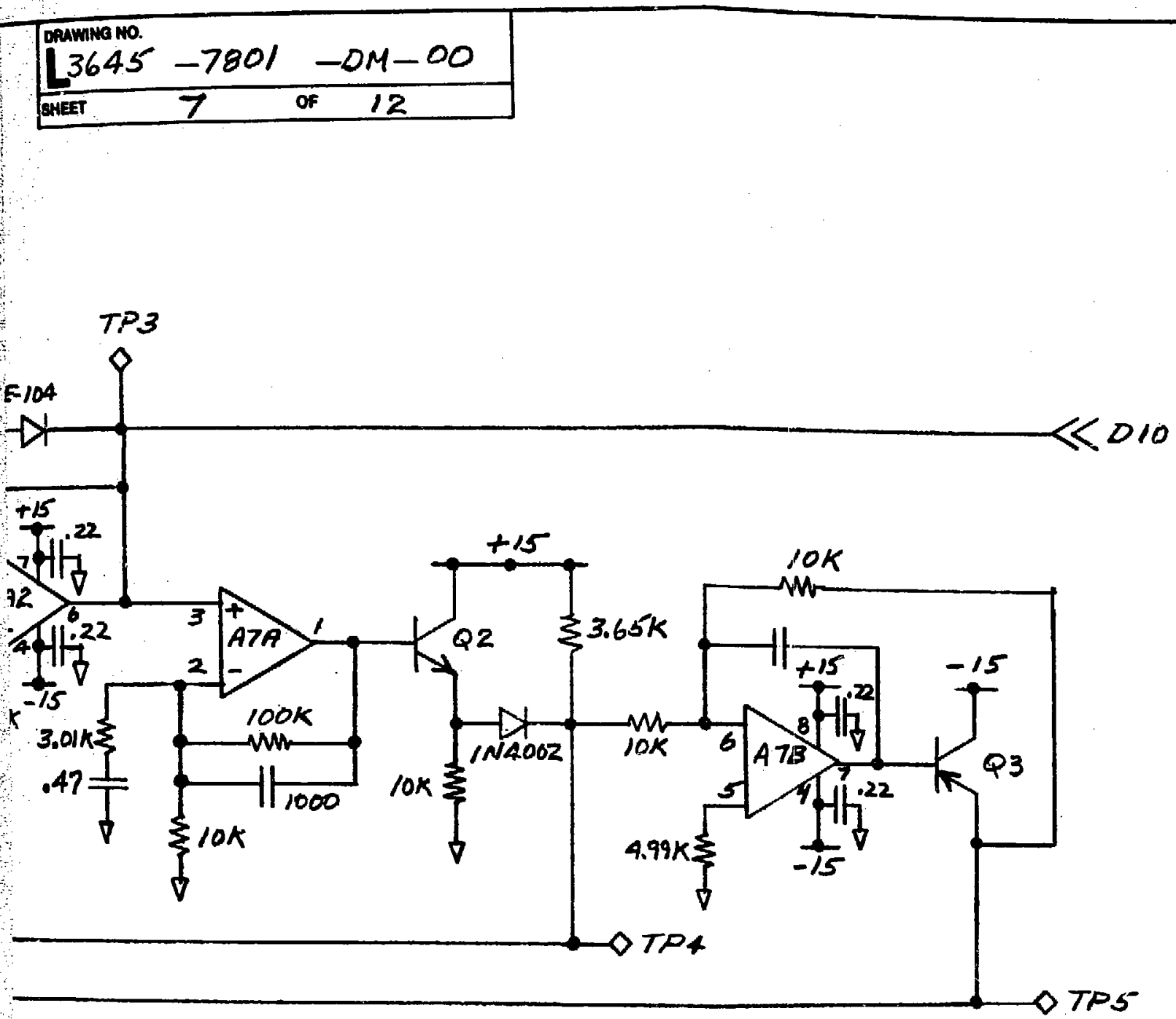

AlD CAL NOTES " 1 " REFERS TO TEST POINTS ON SUB PANEL if (+10.000) 2 - " $\gg$ " REFERS TO PIN ON CARD EDGE CONN. 3 - DX REAERS TO DIAGNOSTIC NO. (SEE SHEET 10) 4. AI F A2 ARE B.B. $3510 \mathrm{CM}$.

$5-A 7$ IS RC 4558DN

$7(+1.000) \quad 6-Q 1 E$ QB ARE 2N4036, QR $152 N 2405$

7 - ALL RESISTORS ARE Y/ WATT M.F. EXCEPT "*" ARE VISHAY

8 - PART OF 6PCO5O; REST ON SHEET 8. 5102.

9 - CIRCUITRY ON SHEETS 7 SB ENCLOSED IN TA CHAMBER.

ing

TITLE

REVISION
Ho.

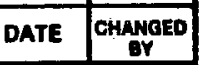

Tiv
of

F.A.EA. SMALL SAMPLE CALORIMETER TR CONTROL

\begin{tabular}{|l|l|}
\hline DESIGN BY EA JUNG & BUILT FO R. PERRY
\end{tabular}

$3546-7801-2 B-00$

DATE 1-24-78 MODEL NO CDP 29

ANL 392 (7-76) 


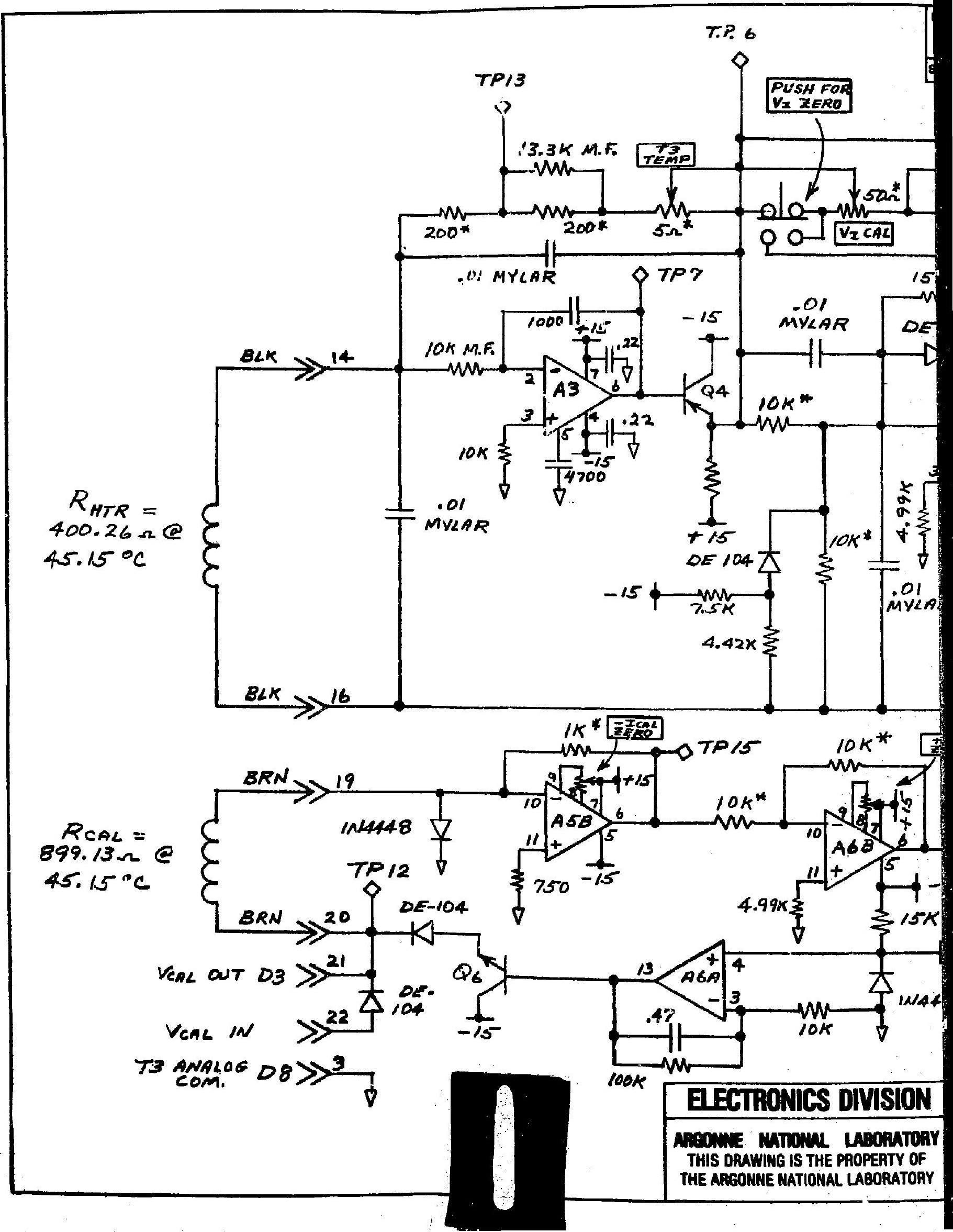


42

\begin{tabular}{l}
$3645-7801-D B-00$ \\
$8 \quad$ OF 12 \\
\hline Met
\end{tabular}

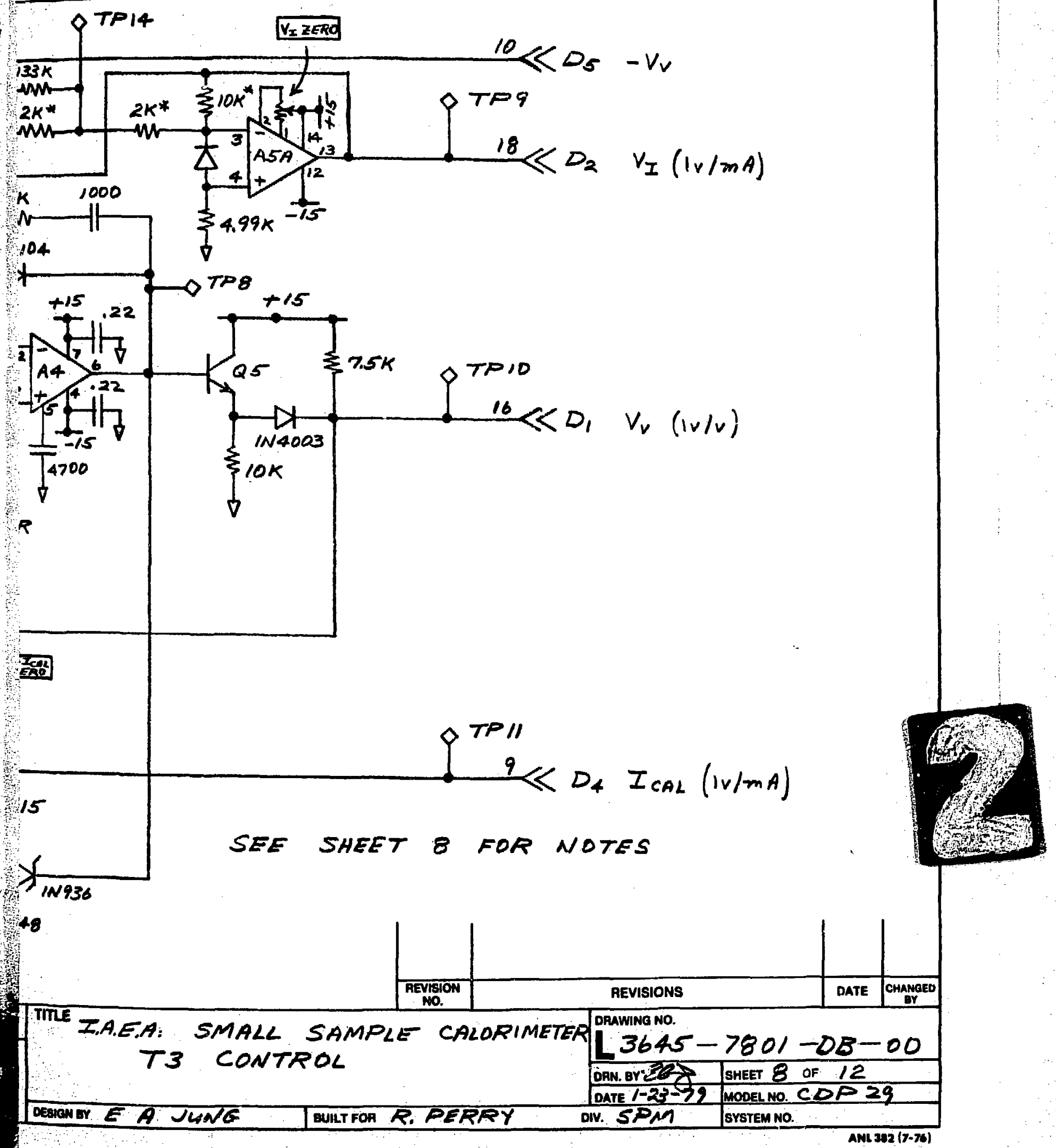


NOTES FOR TI CONTROL

1 - " $\diamond$ " REFERS TO TEST POINTS ON SUB PANEL

2 - " $\gg$ " REFERS TO PIN ON CARD EDGE CONNECTOR

3 - "DX" Refers to DIAGNOSTIC No. (SEE SHEET 10)

4 - AB EAT ARE BiB. $3510 \mathrm{cM}$

5 - AS FAG ARE OPIOCY

6- Q4 \& Q6 ARE $2 N 2405$

7 - PS 15 2N4036

8 - ALL RESISTORS MARKED" * DENOTES VISHAY 5102

9 - PART OF 6PCO50; REST ON SHEET 6.

10 - CIRCUITRY ON SHEETS GET ENCLOSED IN TA CHAMBER

ELECTRONICS DIVISI

THIS DRAWING IS THE PROPERTY
THEARGOWE

THE ARGONNE NATIONAL LABORA 
43

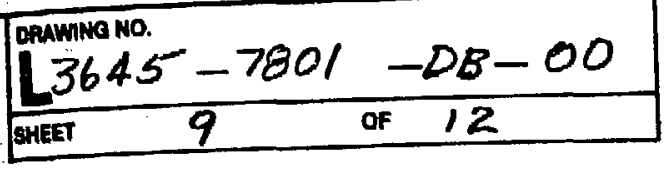

TS ZERO \& CALIBRATION PROCEDURE

1 - ADJ ITEM FOR DESIRED OPERATING TEMP.

2 - ALLOW SUFFICIENT TIME FOR INSTRUMENT TO REACH STABILIZED OPERATING CONDITIONS.

HOR COLL ELECTROMETER CAL

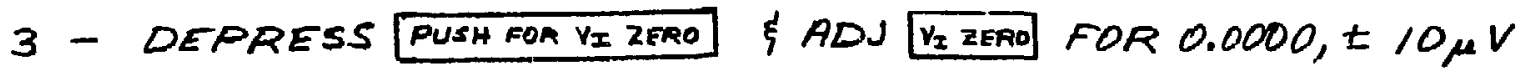

4 - CONNECT A HI Z DVM FROM TD 13 TO TPI4. ADJ $Y_{X} C A L$ FOR $0.0000 \mathrm{~V}, \pm 10 \mu \mathrm{V}$.

CAL COIL ELECTROMETER CAL

5 - CONNECT JUMPER FROM TAIL TO TP15.

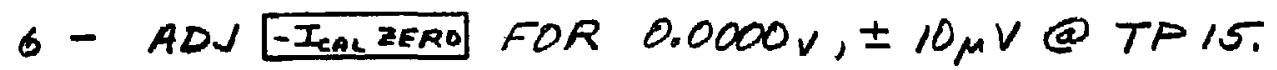

7 - ADJ TICAL FPO FOR $0.0000 \mathrm{~V}, \pm 20 \mu \mathrm{V}$ C TD II.

8 - REMOVE JUMPER FROM TAIL $\xi^{\prime} 15$.

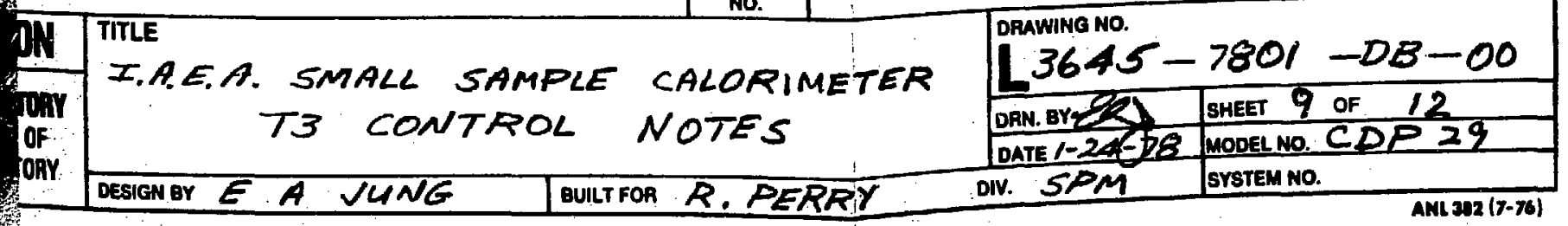




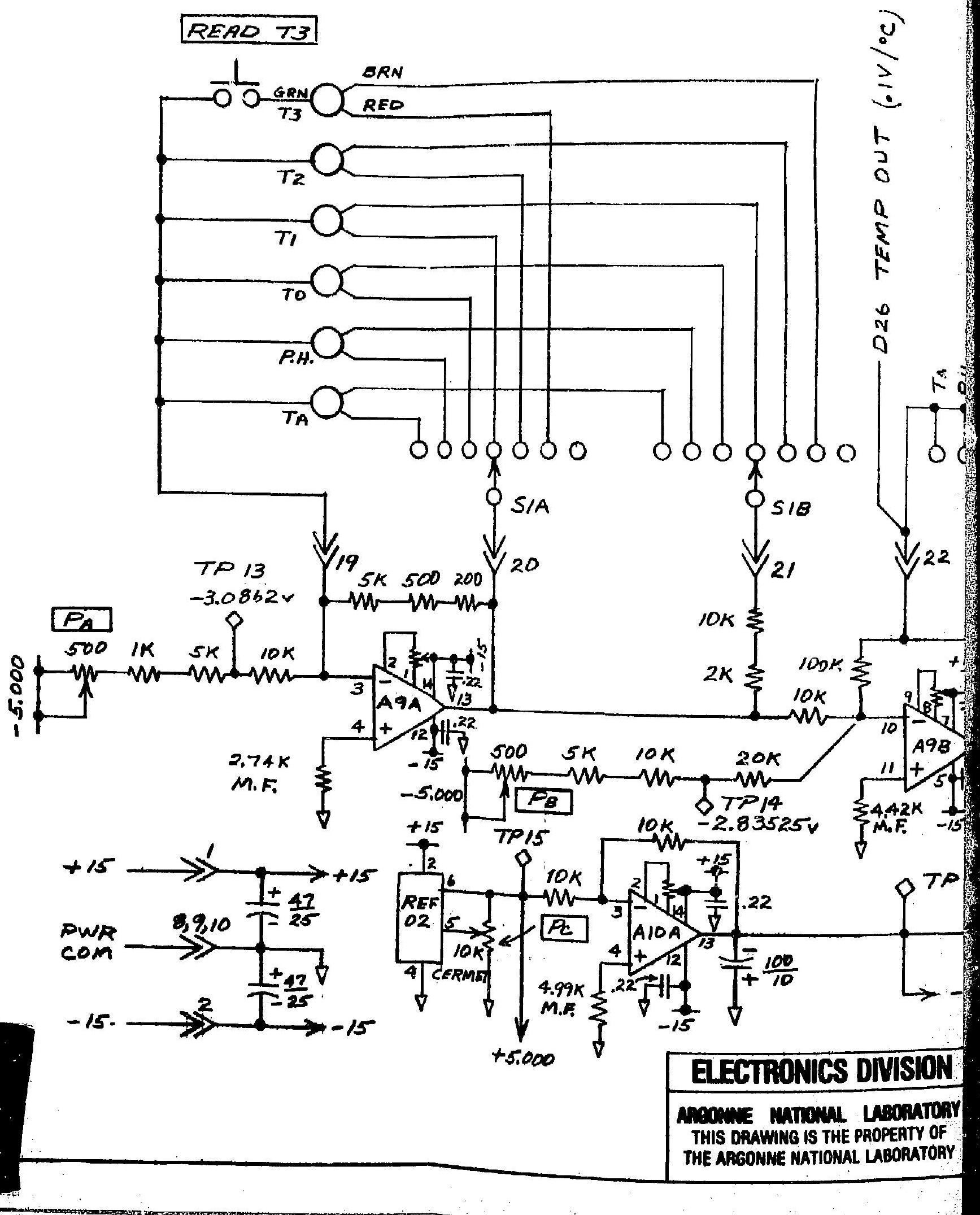




$\frac{3645-7801-D B-00}{10}$

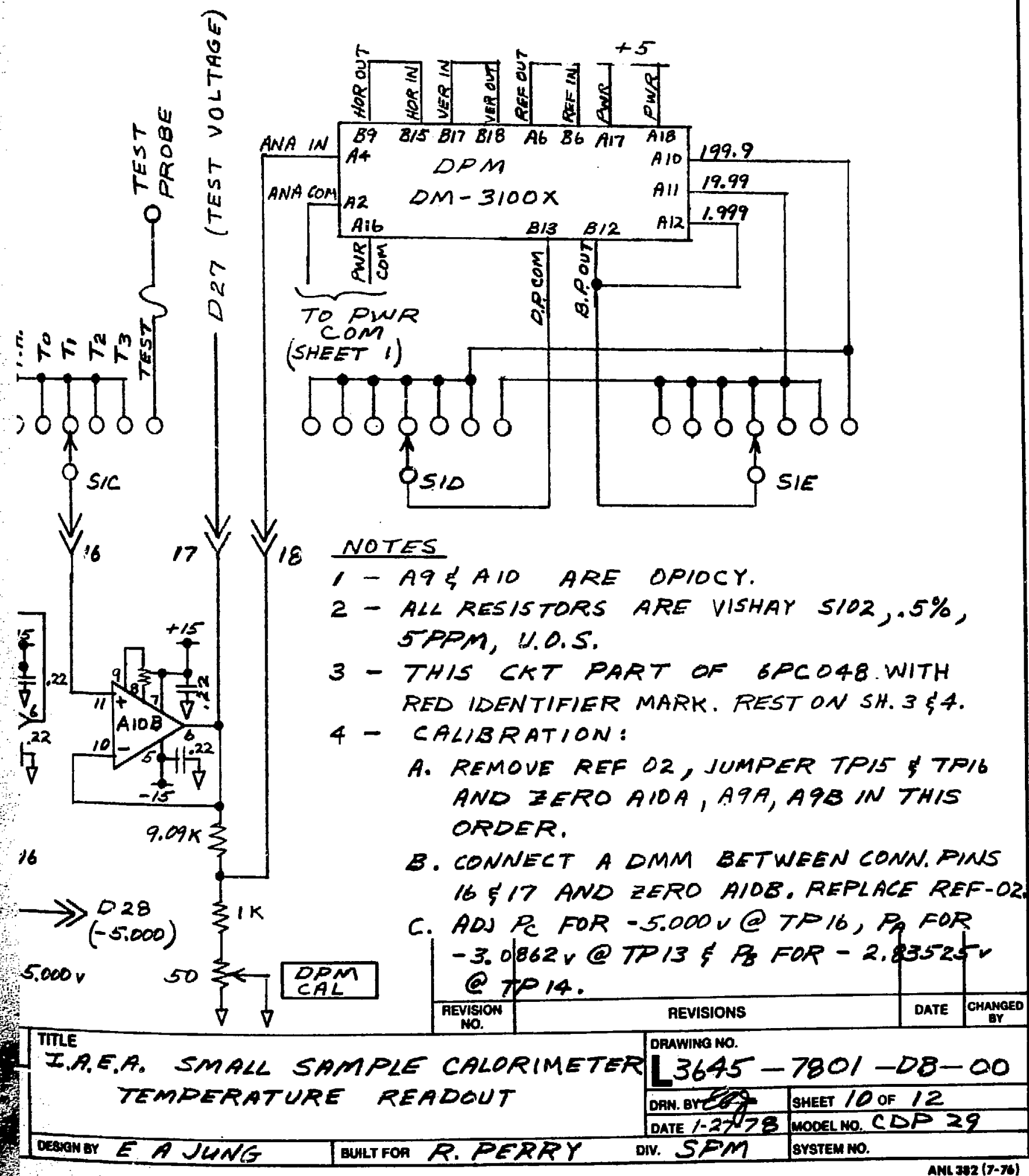




\section{DIAGNOSTICS}

\begin{tabular}{|c|c|c|c|}
\hline DIAG \# & DESCRIPTION & CAPD & $P \mathbb{N} \#$ \\
\hline $\boldsymbol{l}$ & T3 COL VOLTAGE (IV/V) & $73(B O X)$ & 16 \\
\hline 2 & TS COIL CURRENT $(1 \mathrm{v} / \mathrm{m} A)$ & 73 & 18 \\
\hline 3 & 73 CAL COLL VOLTAGE $(1 \mathrm{~V} / \mathrm{V})$ & 73 & 21 \\
\hline 4 & T3 CAL COIL CURRENT (IV/mA) & T3 & 9 \\
\hline 5 & T3 Q4 EMITTER & 73 & 10 \\
\hline 6 & A/O CAL REF, 10.000 & 73 & .15 \\
\hline 7 & A/D CAL REF, 1.0000 & $T 3$ & 7 \\
\hline 8 & T3 SIGNAL COM & 73 & 3 \\
\hline 9 & T22 QI EMITTER & 72 & 4 \\
\hline 10 & T2 A2 OUTPUT & $T 2$ & 8 \\
\hline $7 /$ & TZ HTR VOLTHGE & 72 & 7 \\
\hline 12 & T2 BOOST COIL VOLTAGE & $72 \quad 11$ & 6 \\
\hline 13 & TI AG OUTPUT & $T$ T) BLUE & 80) 17$. \\
\hline 14 & TI A7. OUTPUT & TI & 118 \\
\hline 15 & TI HI HTR VOLTAGE & $T /$ & 1121 \\
\hline 16 & TI LO HTR VOLTAGE & $T$ & $11 \quad 19$ \\
\hline 17 & TO AI OUTPUT & $\overline{T O}$ & 115 \\
\hline 18 & TO A2 OUTPUT & TO & 116 \\
\hline 19 & TO HTA VOLTAGE & 7011 & 1111 \\
\hline 20 & TA AIA OUTPLT & TA (RED & 30) 5 \\
\hline 21 & TA AIB OUTPUT & $T A$ & 113 \\
\hline 22 & TA QR COLLECTOR & $T A$ & 6 \\
\hline 23 & PH. AFA OUTPUT & P.H. & $11 \quad 12$ \\
\hline 24 & PH. ASB OUTPUT & P.H. " & 117 \\
\hline 25 & P.H. ATP, VOLTAEE & P.H. $\|$ & $11 / 3$ \\
\hline 26 & TEMP READOUT $\left(.1 \mathrm{~V} /{ }^{\circ} \mathrm{C}\right)$ & TEMP $"$ & $\| 22$ \\
\hline 27 & TEST PROEE VOLTAGE & TEMP $"$ & 1117 \\
\hline 28 & TEMP READOUT REF, -5.000 & TEMP $"$ & 1115 \\
\hline 29 & SPAAE & - & \\
\hline 30 & + 5 SUPPLY & $+5 \vee 8$ & Us \\
\hline $\begin{array}{l}31 \\
32\end{array}$ & $\begin{array}{l}+15 \text { SUPPLY } \div 2 \\
-15 \text { SUPPLY }+2\end{array}$ & $\begin{array}{ll}+15 V & B \\
-15 & 80\end{array}$ & $\begin{array}{l}\text { US } \\
\text { US }\end{array}$ \\
\hline
\end{tabular}

\section{ELECTRONICS DIVISI}

MEOOWE MATOWL LABOPN

THIS DRAWING IS THE PROPERTY THE ARGONNE NATIONAL LABORAII 
45

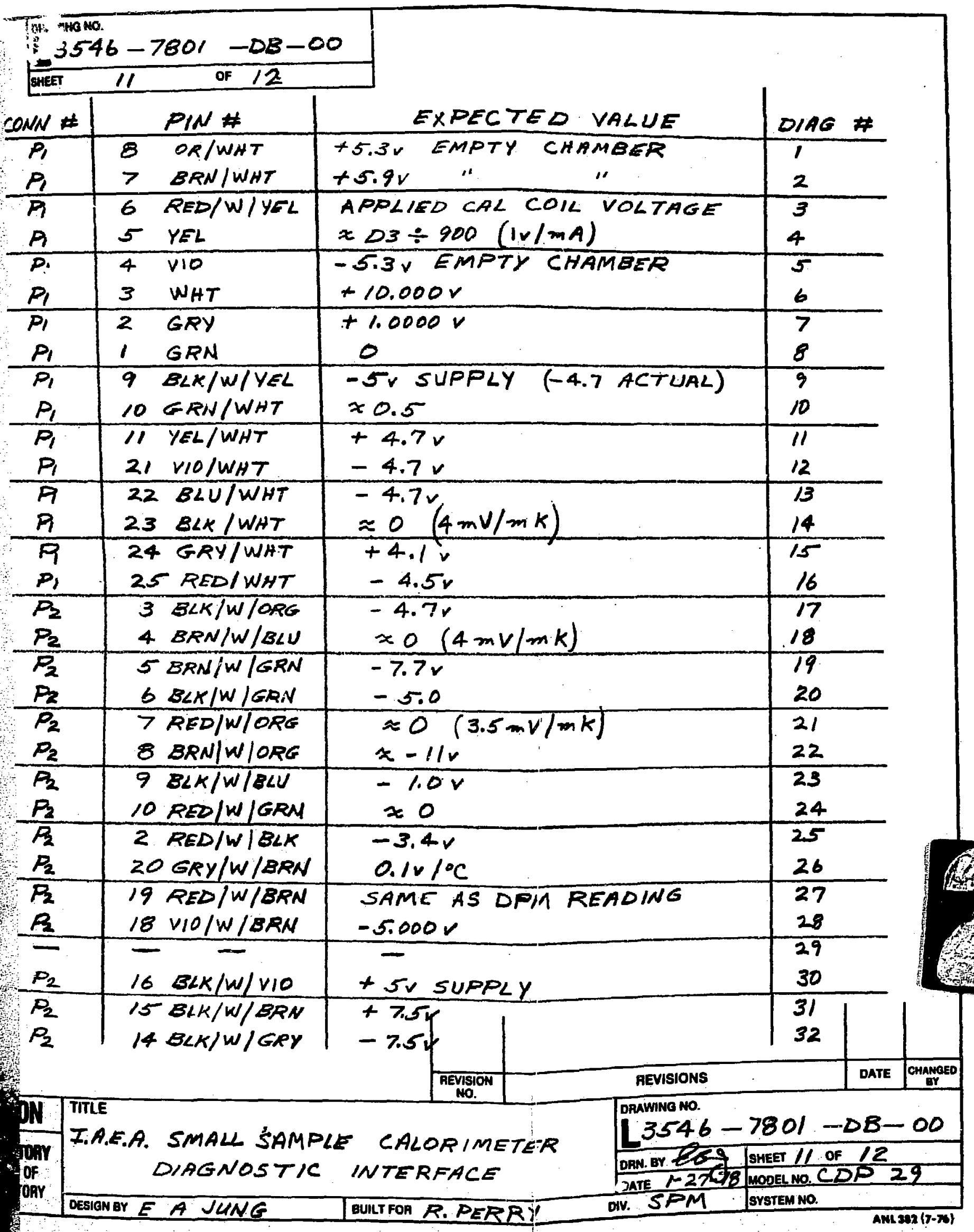




\begin{tabular}{|c|c|c|c|c|c|c|c|}
\hline R & $-N M t$ & $\mid \begin{array}{lll}b & 0\end{array}$ & $\alpha ?=?$ & $m \pm 10$ & $\cong \infty$ & $\gamma$ & $\sim m+b$ \\
\hline 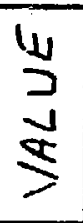 & $\frac{8}{8} \stackrel{R}{0}^{0} 0 \stackrel{\infty}{\frac{\infty}{4}}$ & 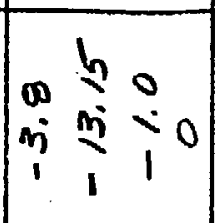 & $\begin{array}{cccc}\infty & n & b & h \\
0 & \vdots & m & n \\
i & + & 1 & 1\end{array}$ & 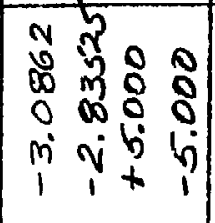 & $\stackrel{0}{x} 1$ & $\begin{array}{l}y \\
j \\
j\end{array}$ & $0 \begin{array}{ll}m+\infty \\
i+x\end{array}$ \\
\hline $\begin{array}{l}Q \\
\bar{Q} \\
U \\
\bar{U} \\
\dot{v} \\
0\end{array}$ & 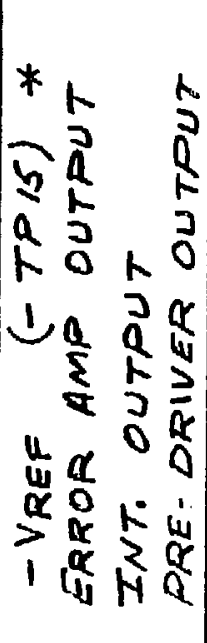 & 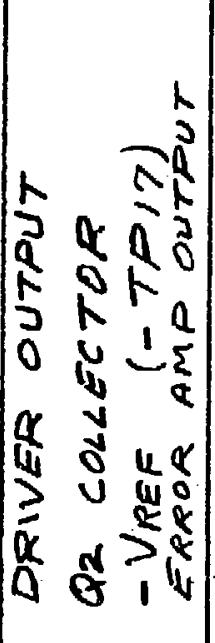 & 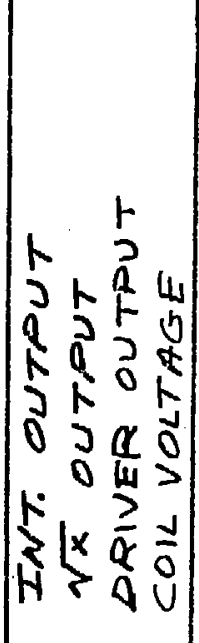 & 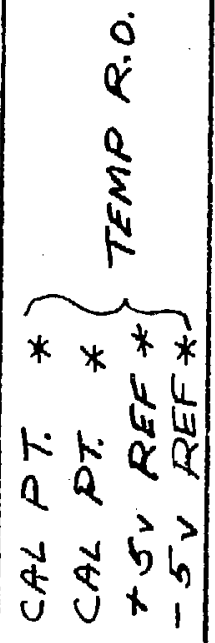 & 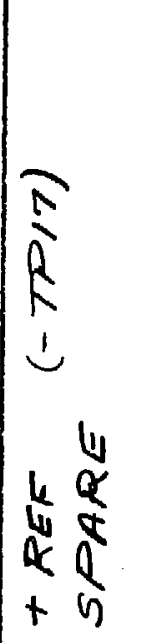 & $\begin{array}{c}u \\
w \\
w \\
2 \\
1\end{array}$ & 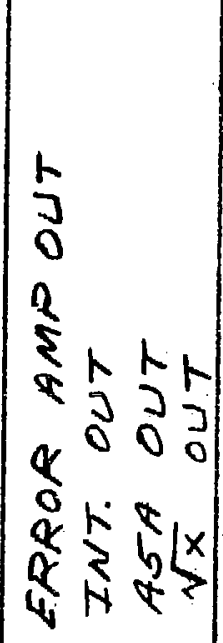 \\
\hline 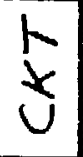 & $\begin{array}{l}R R R \\
\end{array}$ & 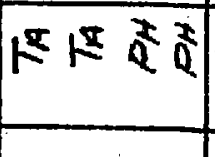 & 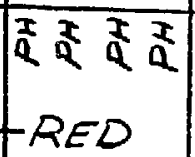 & BD. & $\stackrel{2}{a}$ & $R$ & $R R R R$ \\
\hline$A$ & $r m \forall$ & 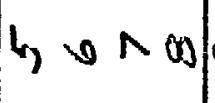 & $\alpha: p=v$ & 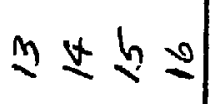 & $\approx \infty$ & Y & $r m+b$ \\
\hline
\end{tabular}

NOTE - ALL TEST VOLTAGES TAKEN WITH ON-BOAA DVM, EXCEPT "*", UNDER EMPTY CHAMBE CONDITIONS WITH P PAL $=0$.

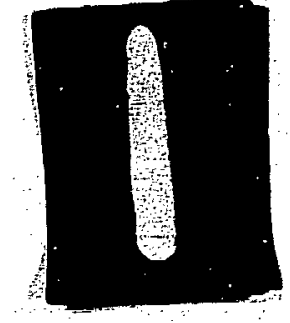




\begin{tabular}{|c|c|c|}
\hline & -7801 & 00 \\
\hline SHEET & 12 & 12 \\
\hline
\end{tabular}

\begin{tabular}{|c|c|c|c|c|c|c|c|}
\hline$-\infty a$ & $\underline{Q}=\underline{N} \underline{m}$ & \pm 6 & - & $N m+b$ & $\Delta \wedge \infty a$ & 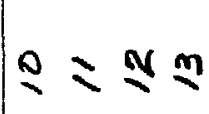 & 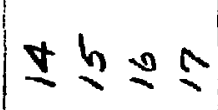 \\
\hline $\begin{array}{ll}n & 1 \\
\vdots & 0 \\
1 & 1\end{array}$ & $\begin{array}{l}-0 \div 0 \\
\dot{v} \dot{j} \dot{j} \\
++t\end{array}$ & $\begin{array}{l}n \\
n \\
j \\
+\end{array}$ & $\begin{array}{l}n \\
n \\
b \\
1\end{array}$ & 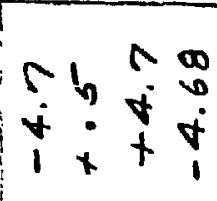 & 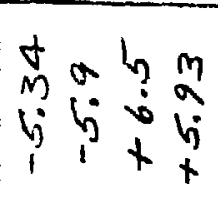 & 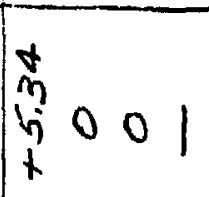 & 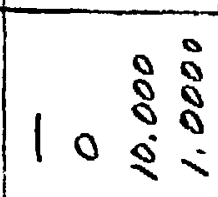 \\
\hline 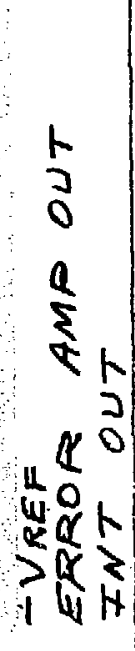 & 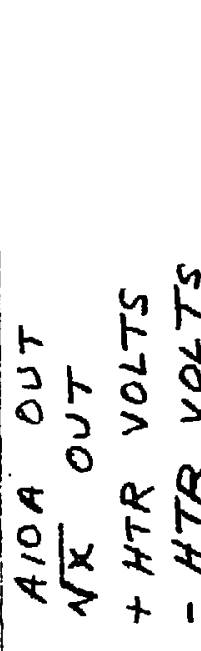 & 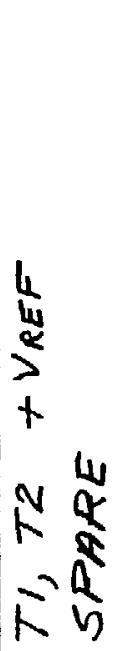 & $\begin{array}{l}5 \\
5 \\
0 \\
\bar{\tau}\end{array}$ & 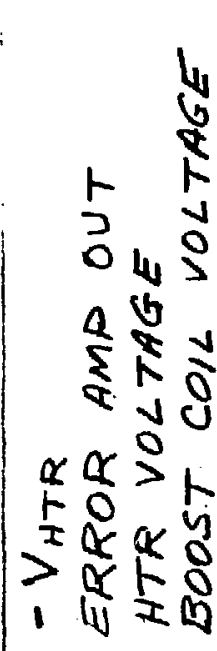 & 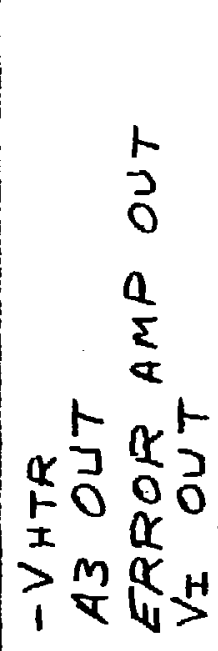 & 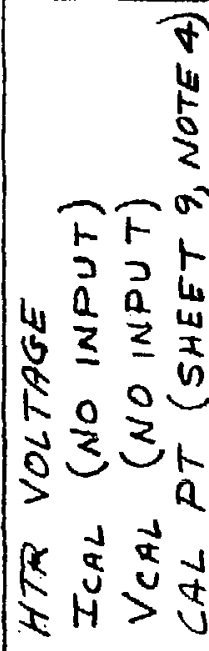 & 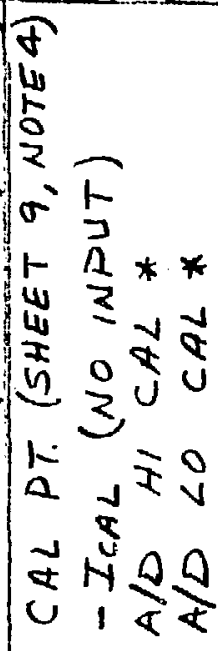 \\
\hline $\begin{array}{l}\text { FR下 } \\
\text { JE }\end{array}$ & $\begin{array}{l}\text { FFFF } \\
B D D\end{array}$ & $=$ & $N$ & $N \mathbb{N} N$ & $-T_{A}$ & $0 x$ & \\
\hline$\therefore \infty a$ & I $\leqslant$ V & \pm 6 & 工 & $v m \forall h$ & ONC & $Q=\mathbb{N}$ V & $\pm 2 * 2$ \\
\hline
\end{tabular}

0

R 
APPENDIX B

DATA ACQUISITION SYSTEM

\section{CIRCUTT DIAGRAMS \#1-7}

1. Keyboard layout and connections

2. Keyboard decode

3. Analog multiplexer

4. Display

5. Analog output

6. Printer output

7. 8085 microprocessor system 


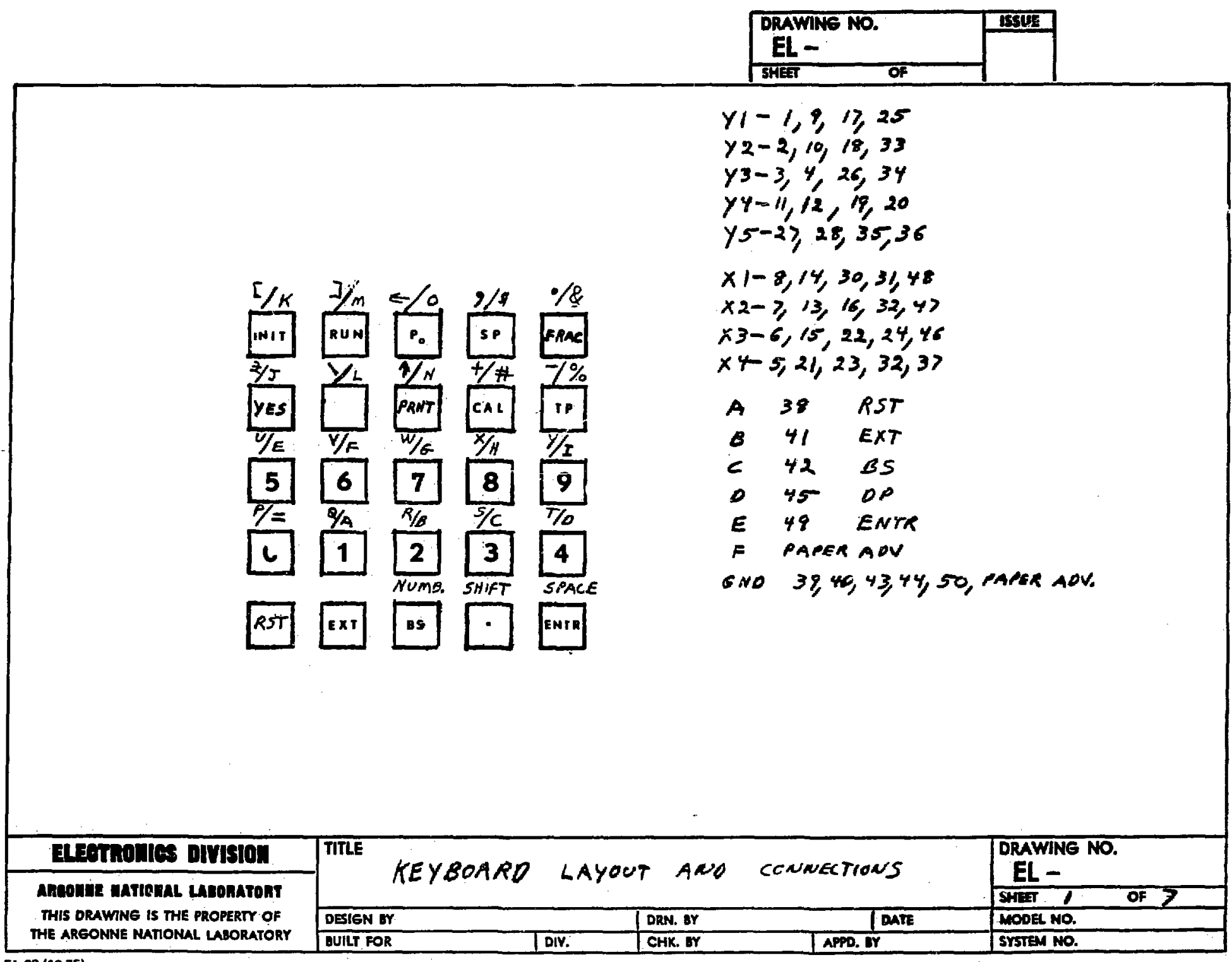




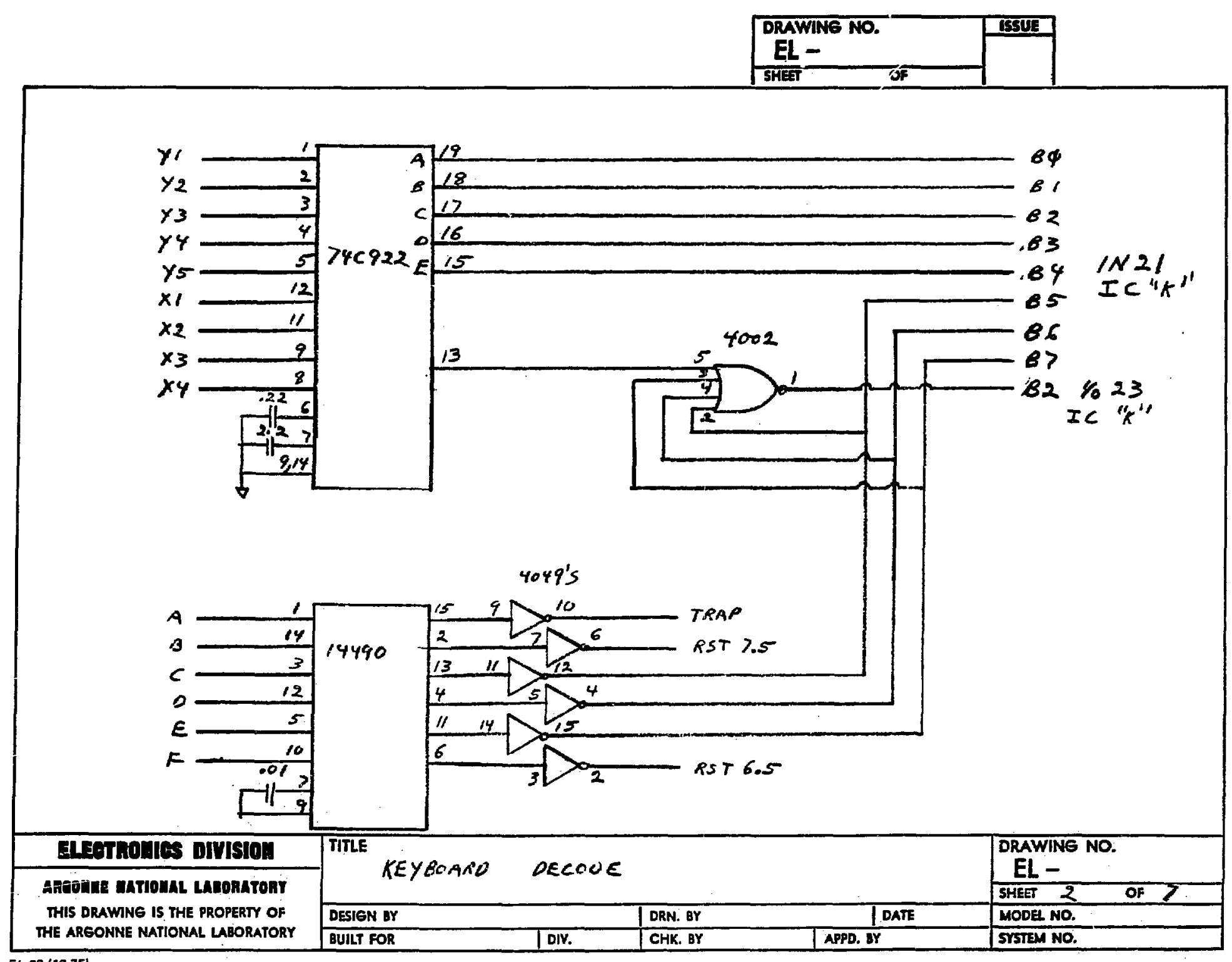




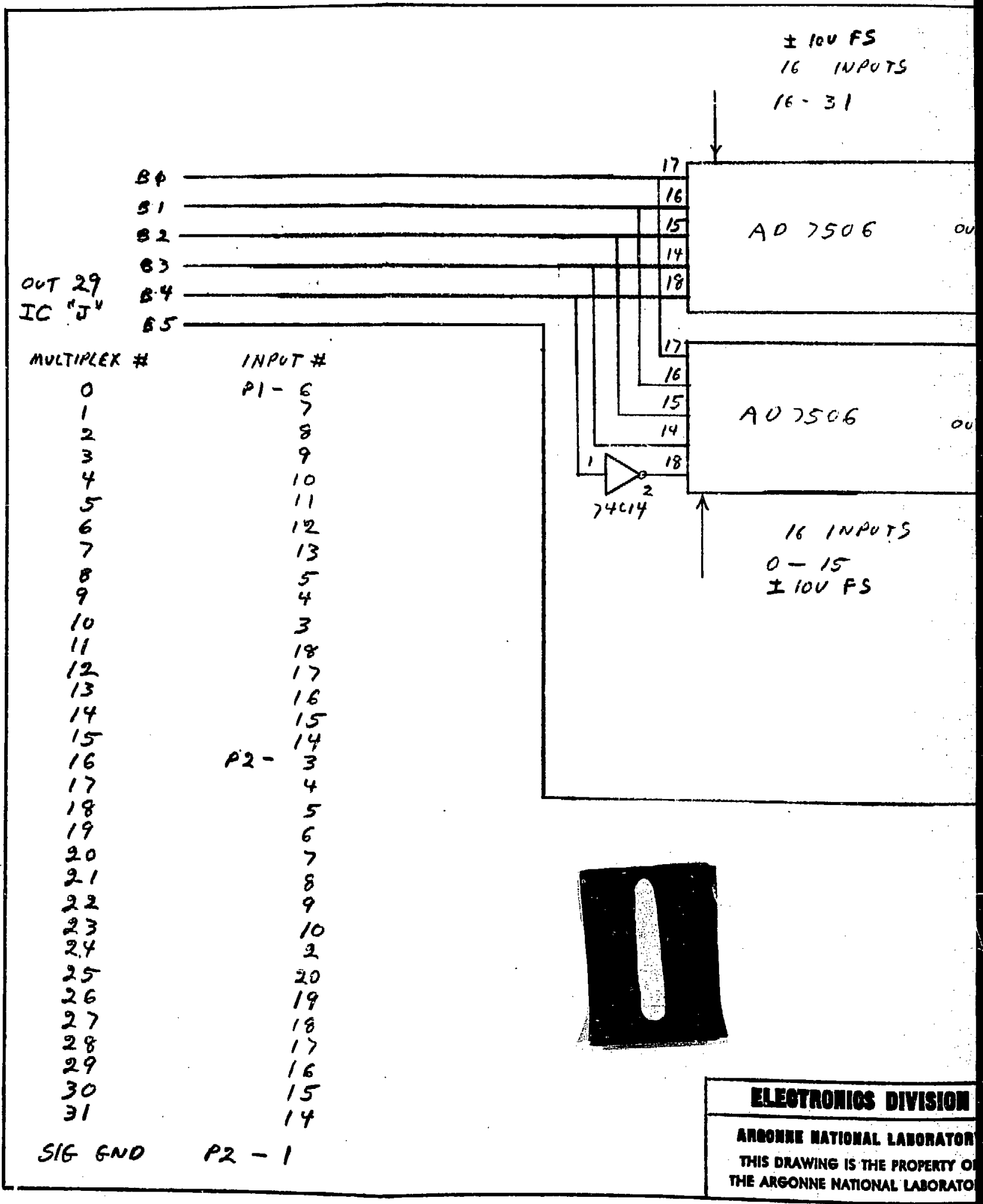




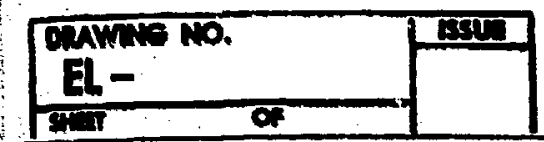

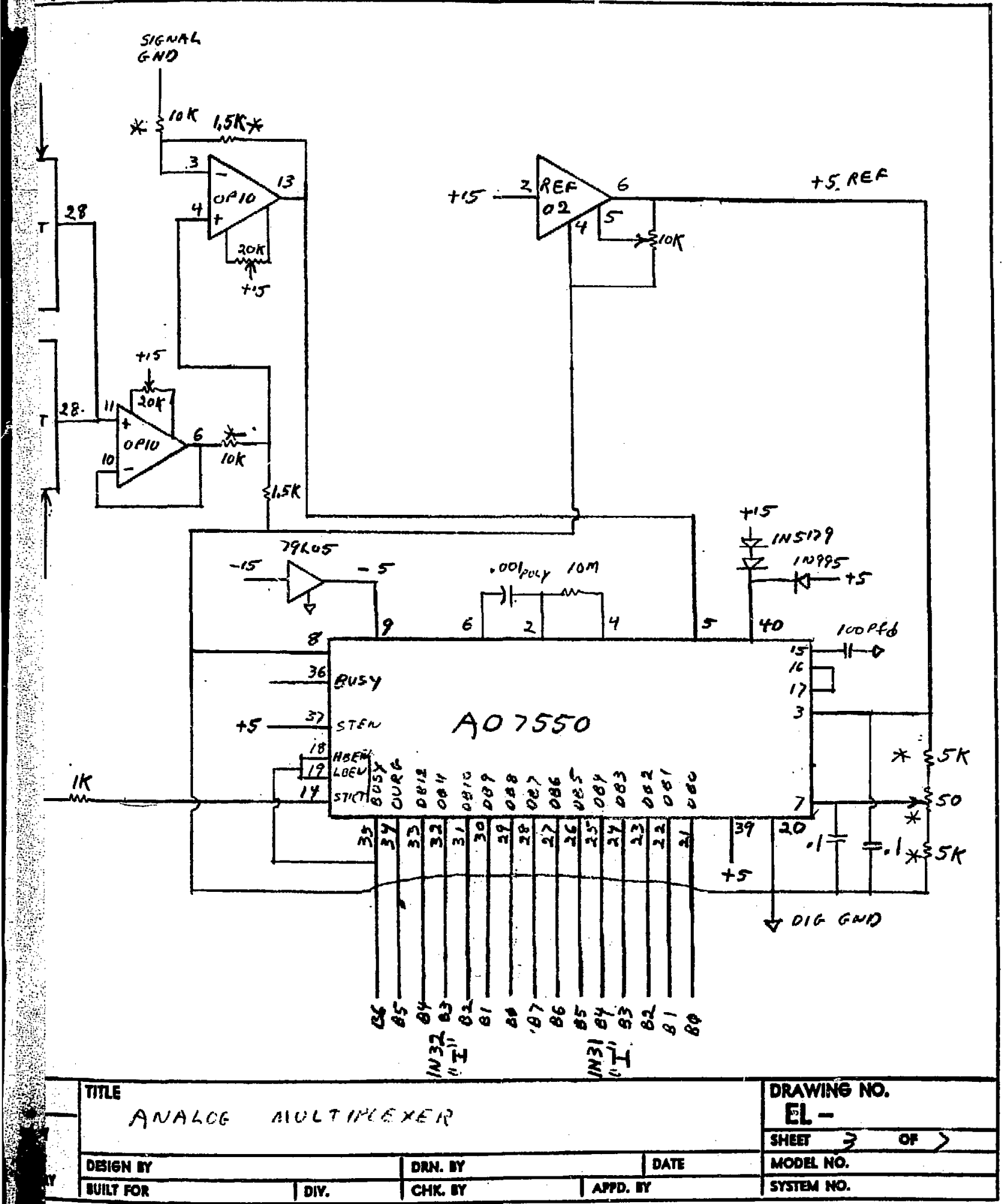




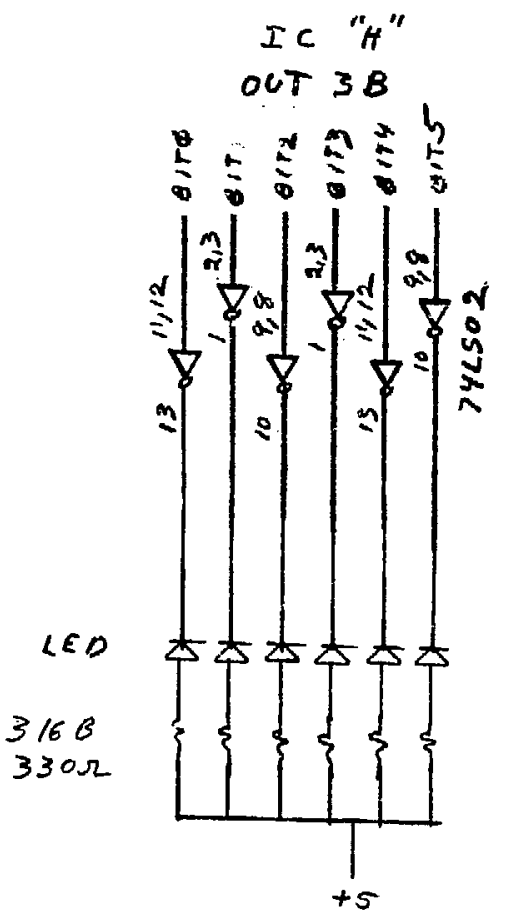



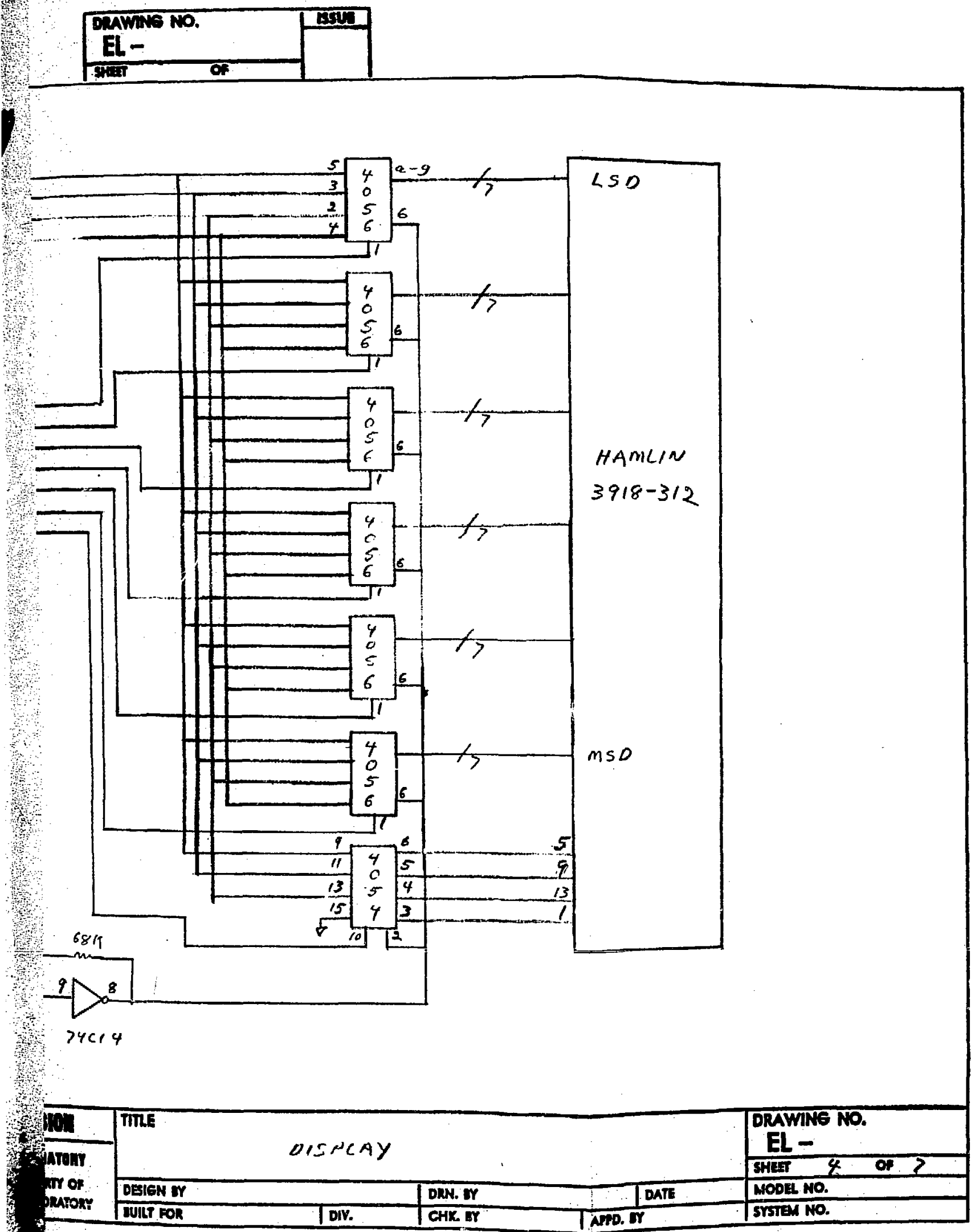

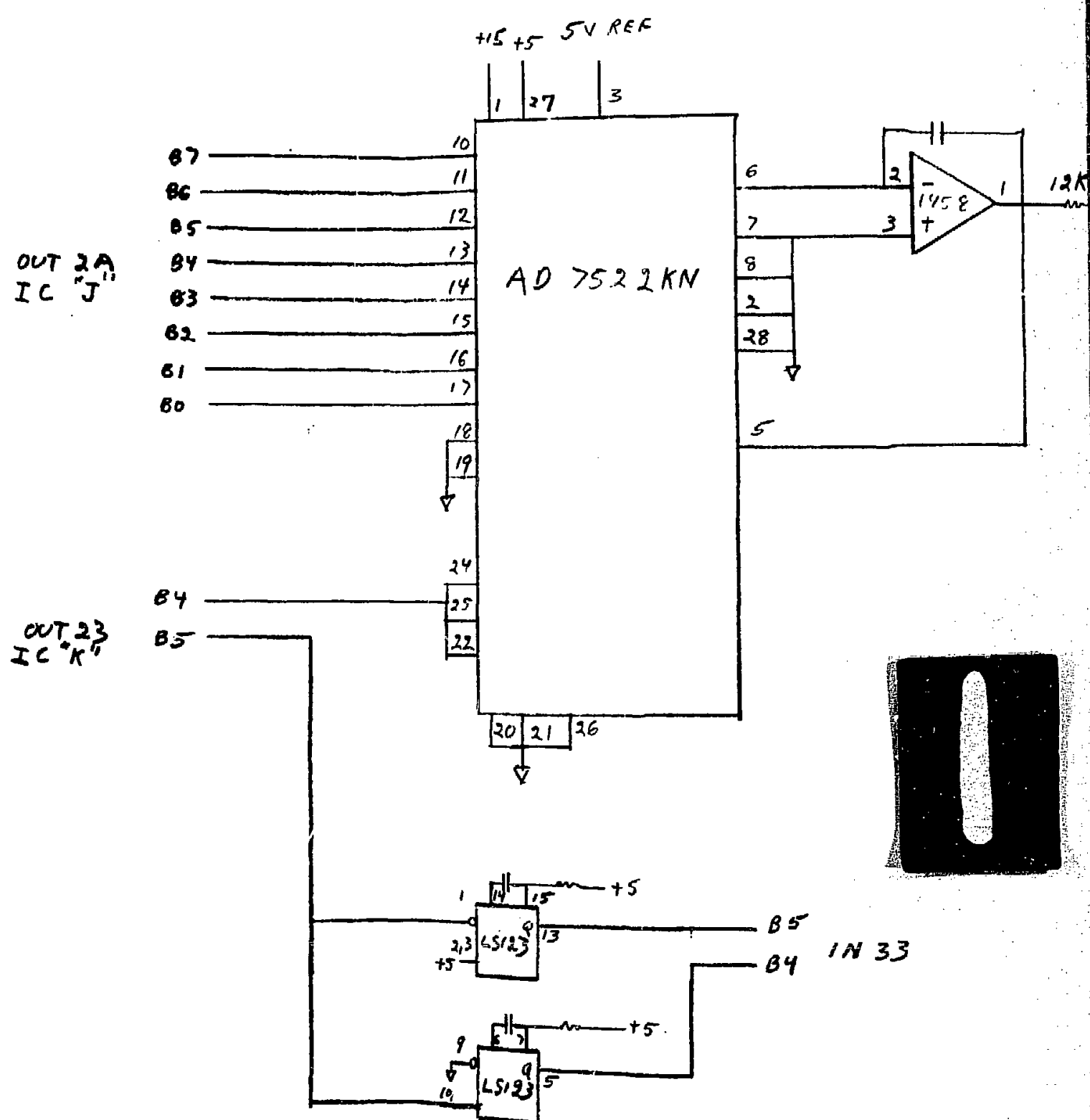


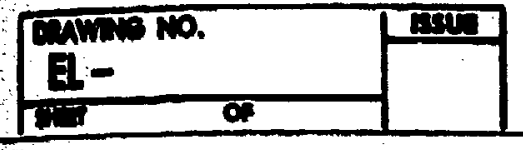

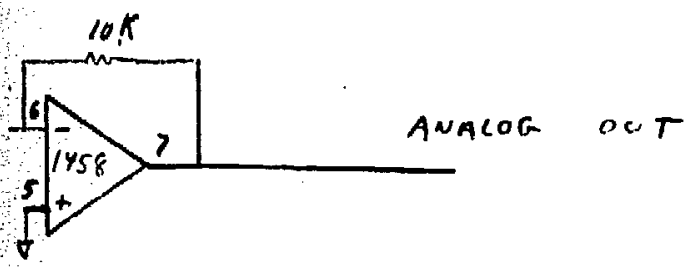

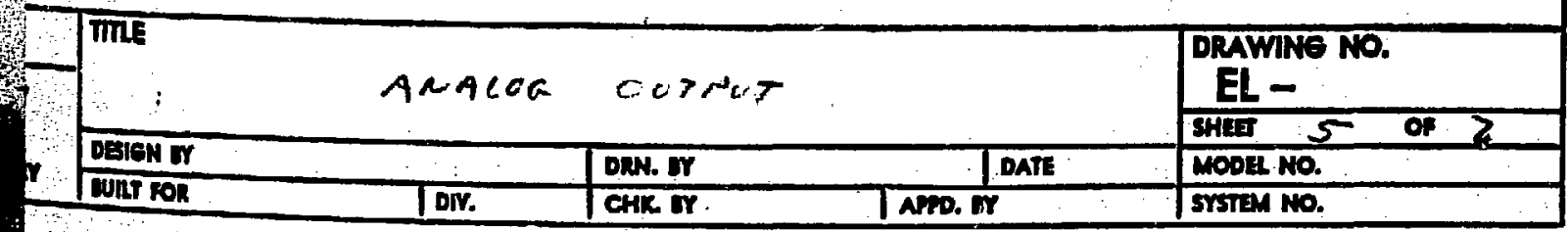





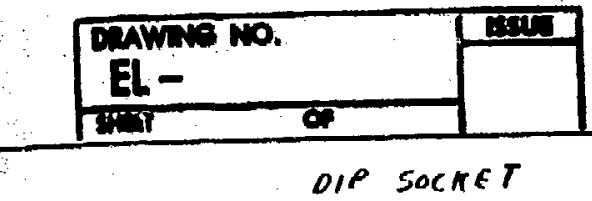

(8) 82

(2) $B 4$

(5) 65

(4) 86

(6) $E>$

(3) 68

(10) $B I$

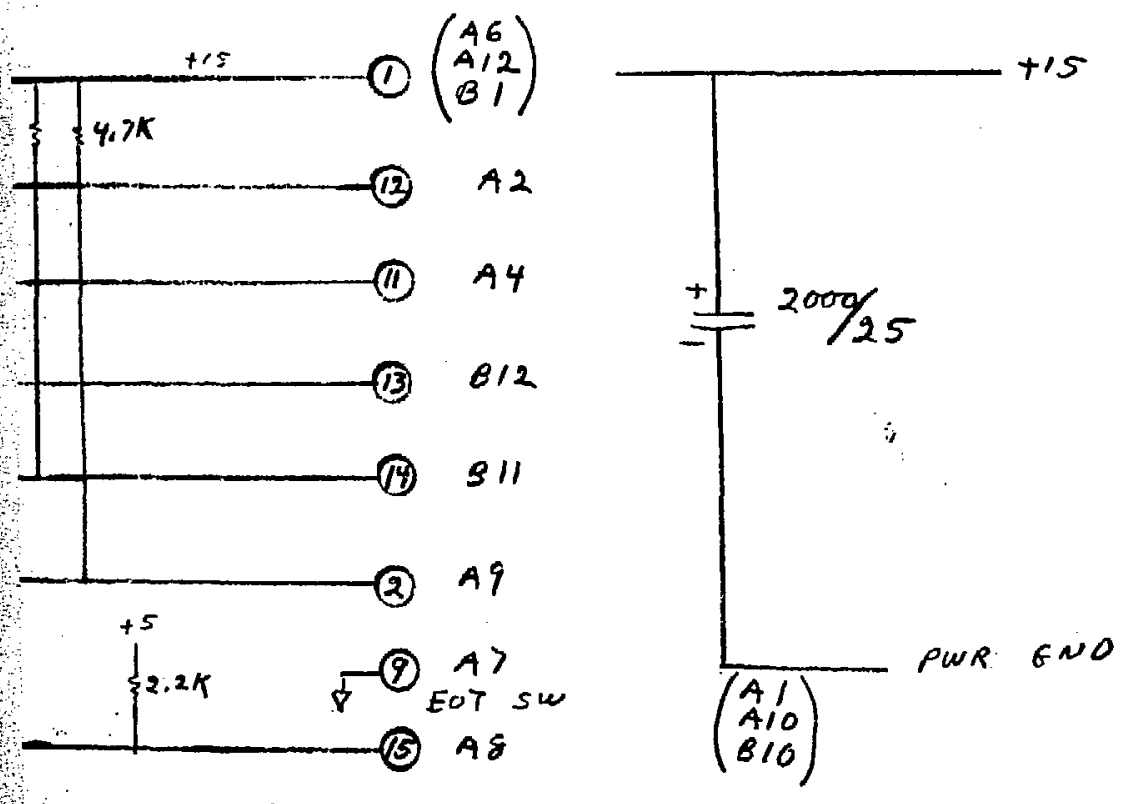

BI

IC "I"

(16) $A I I$

$7 ?$

M.

Aront

or of

penrony
$B \phi$ 


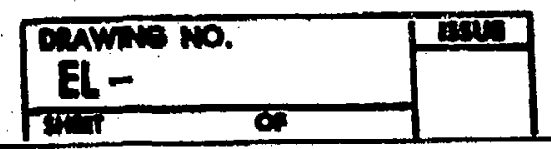

DIP SOCKET

(B) 82

(2) 84

(5) 85

(4) 86

(6) $B>$

(3) 88

(10) $B 9$

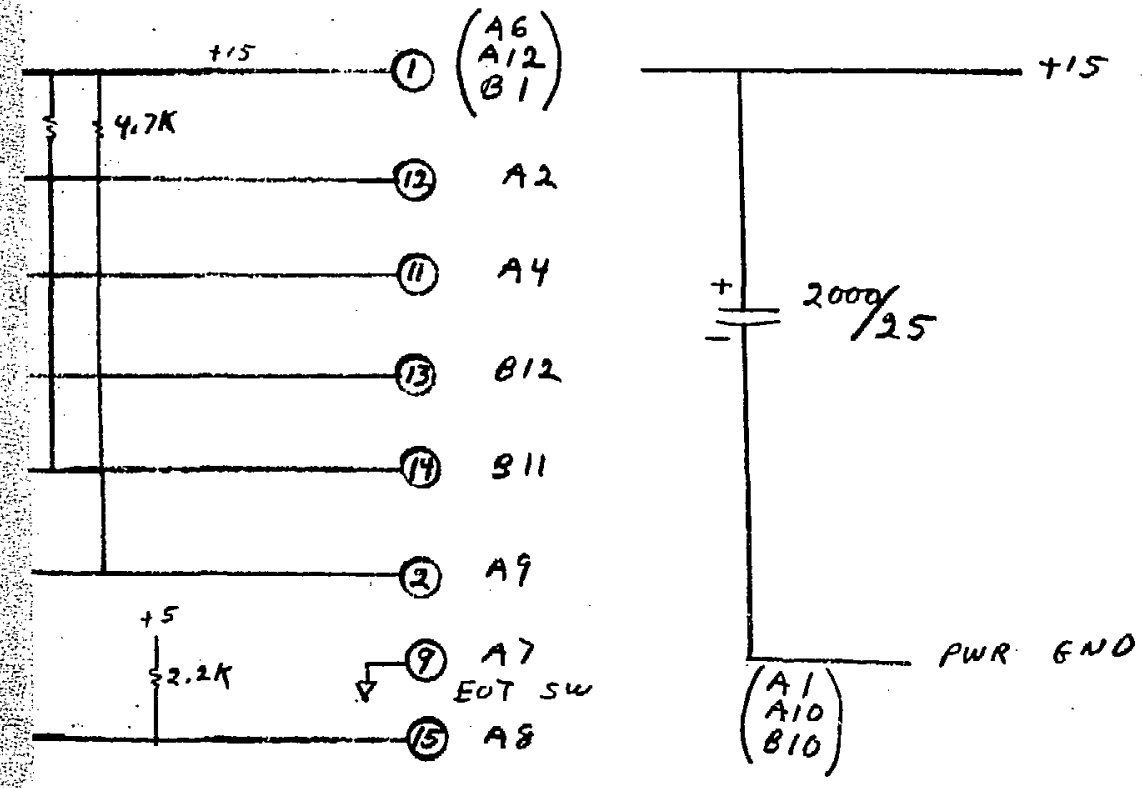

$$
\begin{array}{ll}
\text { BI } 33 \\
I C " I "
\end{array}
$$

\begin{tabular}{|c|c|c|c|c|}
\hline Wh & \multirow{2}{*}{\multicolumn{2}{|c|}{ TITE }} & & $\begin{array}{l}\text { DRAWINO NO. } \\
\text { EL - }\end{array}$ \\
\hline \multirow{3}{*}{$\begin{array}{l}\text { Atent } \\
\text { Mr of } \\
\text { peatony }\end{array}$} & & & & कiva 6 \\
\hline & DEIGN $\overline{Y Y}$ & DRA. $\mathbf{x}$ & DATE & \multirow{2}{*}{\begin{tabular}{|l|} 
MODEL NO. \\
SYSTEM NO. \\
\end{tabular}} \\
\hline & OUILT FOR & CHK IY & & \\
\hline
\end{tabular}

(16) $A I I$ 
APPENDIX B

II. LISTING OF MICROPROCESSOR PROGRAM

Gilni $3 E$ Q6 DIIIE IIJ 30 inilint $\mathrm{SE}$ 4F ninte II $\mathrm{EQ}$ niñe $3 E$ 4 I MIIIA II: 30 GUIiT: $3 E$ 4F GUIUE IS 3 OIIIO $3 E$ OF 0101E IIS उस BII14 $3 E$ SF

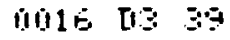
nils $\mathrm{AF}$

1019 II: 30 (I01) IIS $\mathrm{EE}$ IMIII IIS $3 \mathrm{H}$ DOIIF $3 E$ Q0 ONE 1 10 40 OII and 4

0024 ra nive?

noes ra 0070 TileF

DUIA EII IIE DII

आ11:3 $\mathrm{FE}$

inis: 09

ing

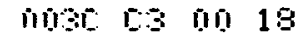

ningF

01040 II: 39

IIIAE $\mathrm{HF}$

0114: IIS 39

0114531 FF 38

01148 EI OIE 05

$014 \mathrm{E} \quad \mathrm{ZE}$

0014I $3 E$ :0 30

OIISO CII IIE

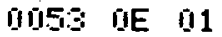

01055 11 nĩ 80

$\begin{array}{lllll}005 & 21 & 0.4 & 30\end{array}$

OUGE CI ET OC

UIJSE DE PE

$005011 \quad 54 \quad \mathrm{I} 4$

0063 al 210

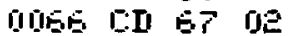

01069 21 on 17

DUES CI CF OO

01SF ED EB 01

01072 21 on 17

DOTS R:T R.F nII

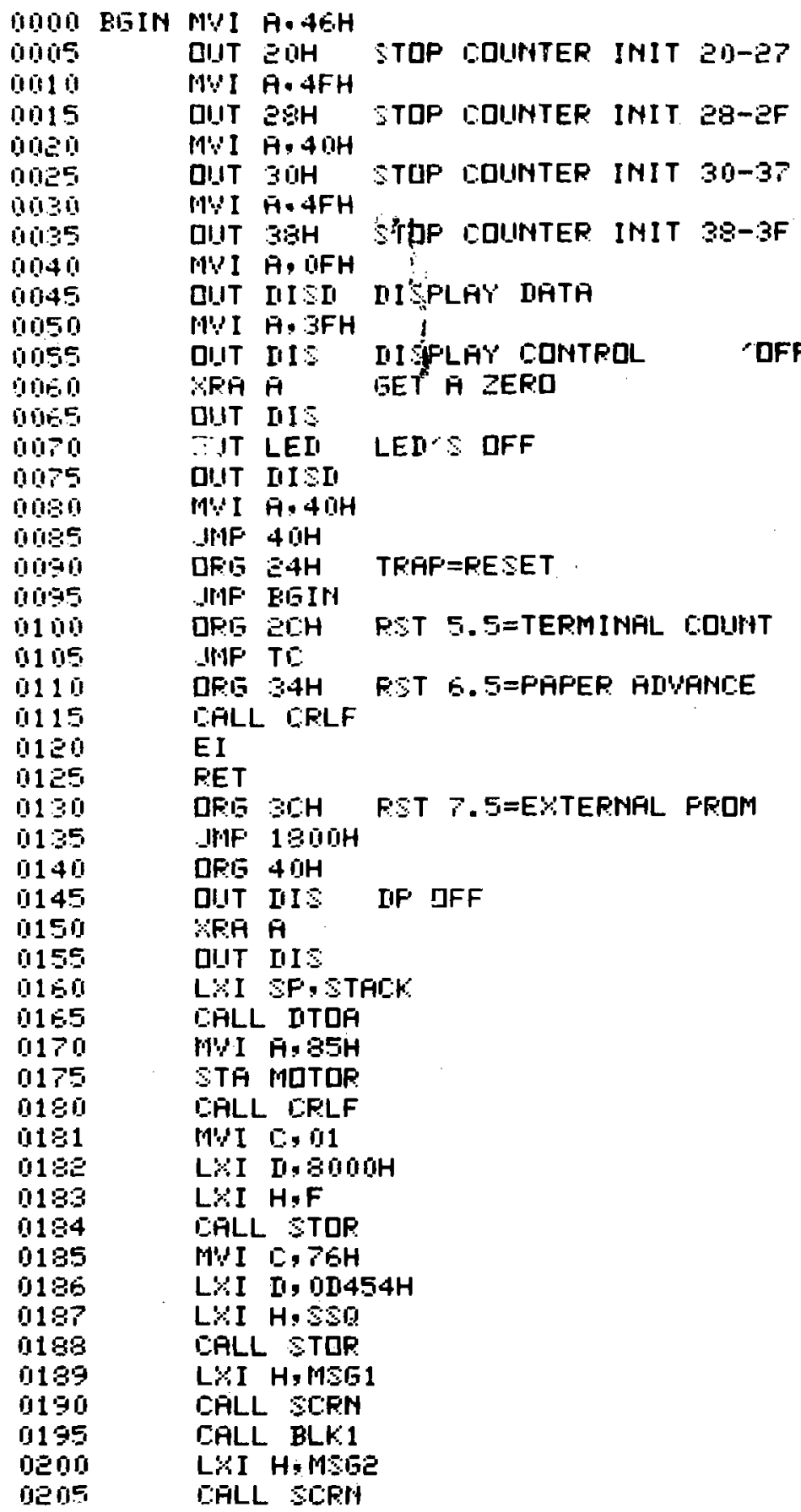




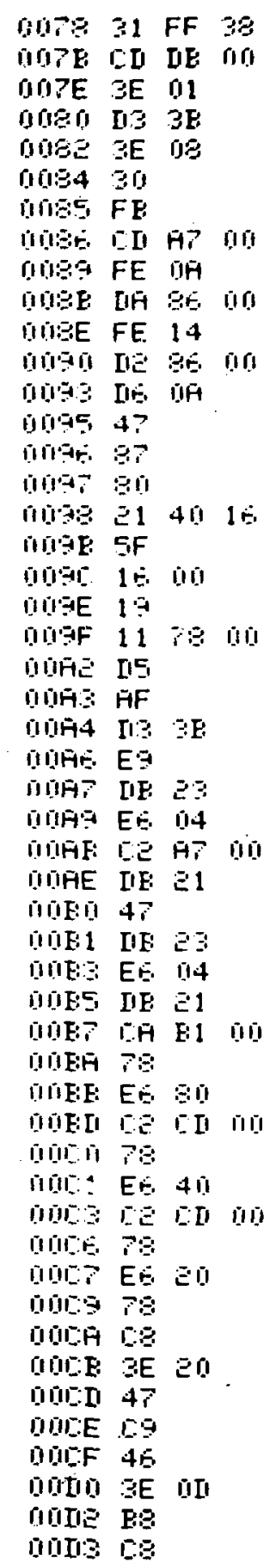

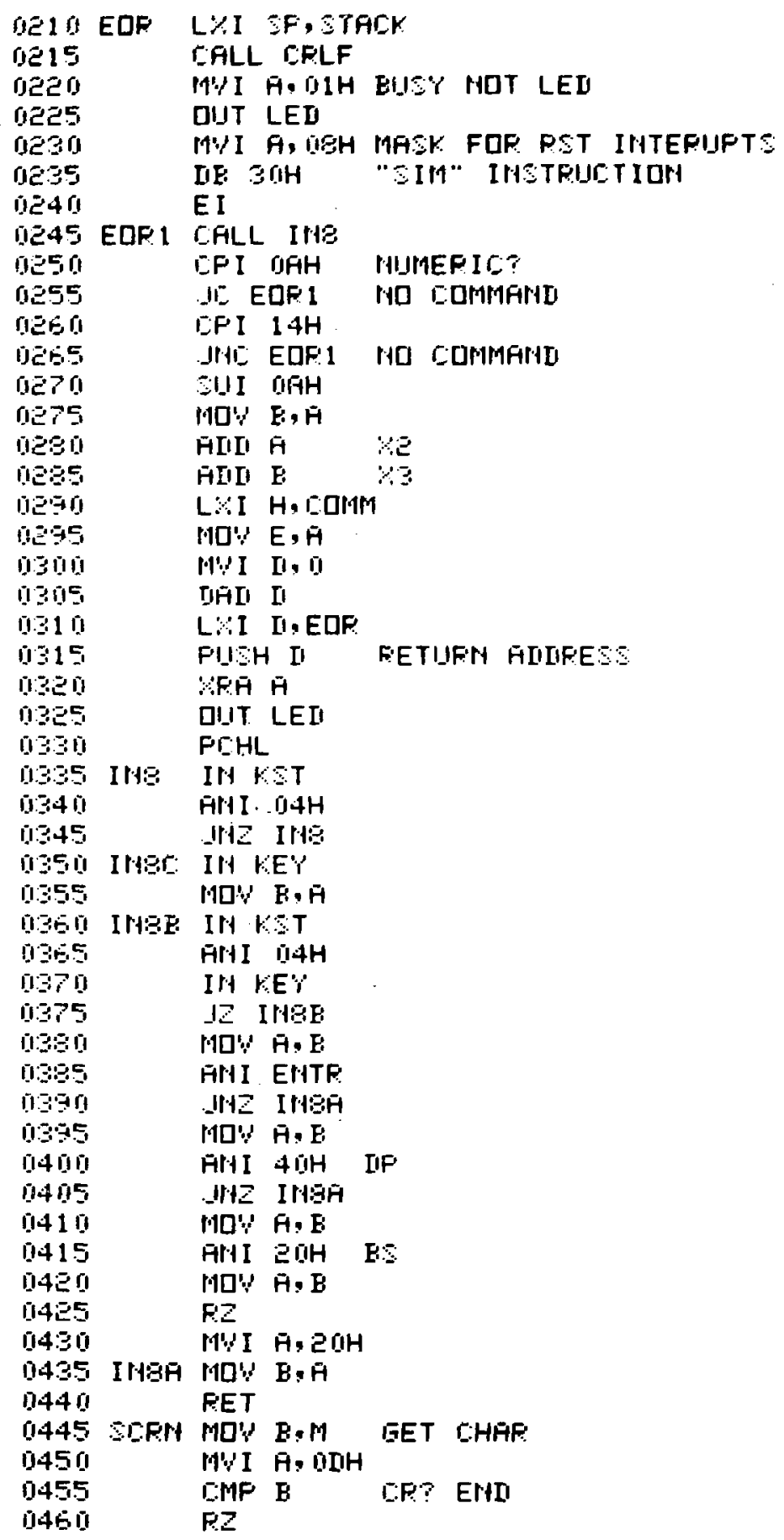




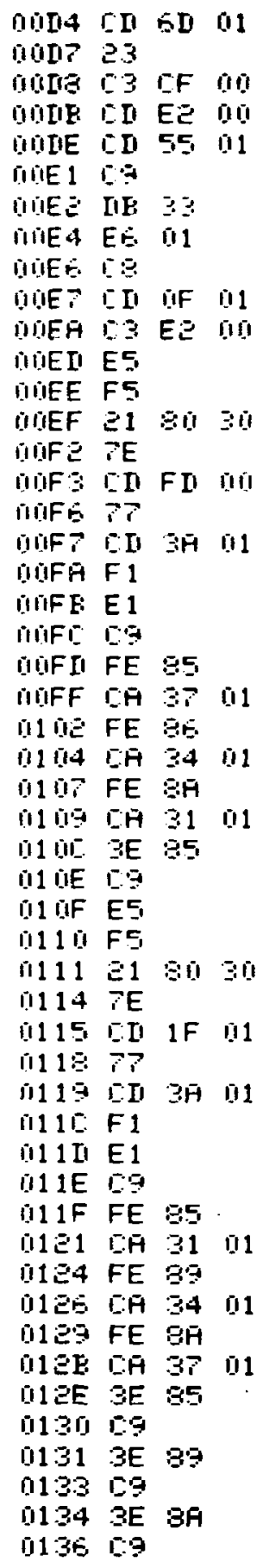




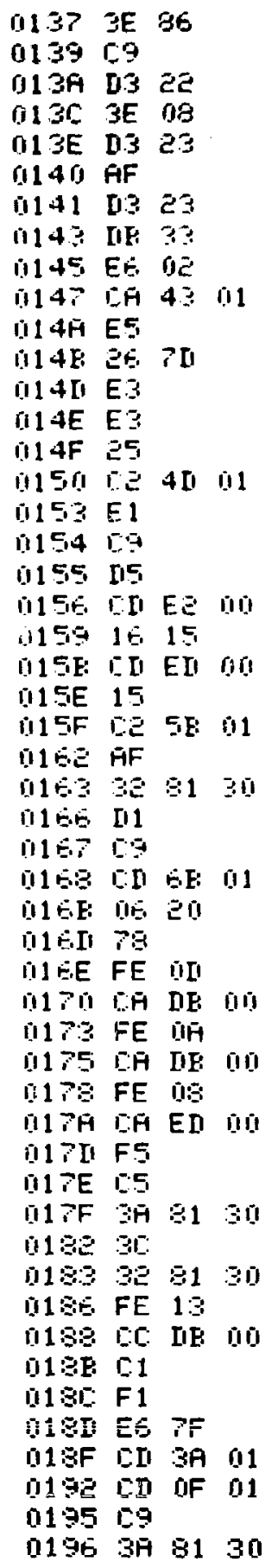

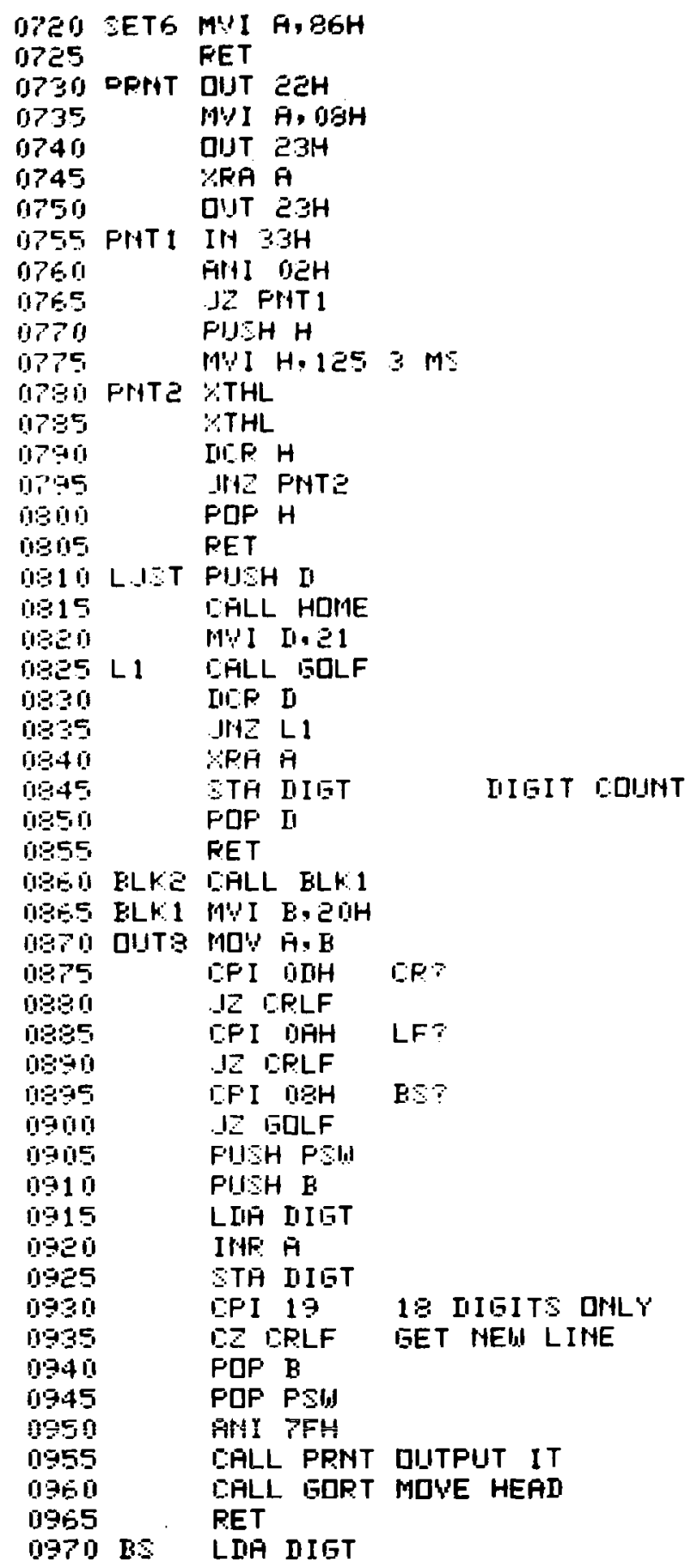




\begin{tabular}{|c|c|c|c|}
\hline 0199 & FE & 00 & \\
\hline $\begin{array}{l}019 B \\
019 E\end{array}$ & $\begin{array}{l}\mathrm{Ce} \\
\mathrm{cg}\end{array}$ & ED & 00 \\
\hline $019 F$ & IB & $3 E$ & \\
\hline (I) 1 & $F 6$ & $n z$ & \\
\hline 01म3 & II:3 & $3 E$ & \\
\hline M1AS & 21 & 00 & FF \\
\hline G19B & 00 & & \\
\hline ज1A & 00 & & \\
\hline ПIमAF & EE & 010 & \\
\hline जIAI & DE & 010 & \\
\hline DIमEE & 11 & 91 & tou \\
\hline IE:1 & $E I$ & EE & 01 \\
\hline 011 E:4 & $4 F$ & & \\
\hline 0185 & $\Gamma \Xi$ & $\therefore 1$ & 01 \\
\hline 01 E: & $\mathrm{mi}$ & & \\
\hline प1E & $7 E$ & & \\
\hline П1 EA & $\mathrm{FE}$ & FF & \\
\hline $01 \mathrm{EL}$ & $E \bar{H}$ & $\exists F$ & 01 \\
\hline MI P.F & 011 & & \\
\hline 0100 & $\operatorname{lin}$ & & \\
\hline 01E1 & $E I$ & EE: & !1 \\
\hline 0104 & 7 & & \\
\hline 0165 & 87 & & \\
\hline $01 \mathrm{CE}$ & 37 & & \\
\hline 1010: & 37 & & \\
\hline M1E & 5.7 & & \\
\hline 0109 & OII & & \\
\hline$M E \bar{H}$ & EII & $E E$ & 01 \\
\hline DIEI & 47 & & \\
\hline OILE & $\vec{F} \bar{H}$ & & \\
\hline G1EF & EE & Fi & \\
\hline $011[11$ & EOI & & \\
\hline П口 LIE' & 57 & & \\
\hline 0113 & EII & E E & 01 \\
\hline ПI IE & 87 & & \\
\hline 01107 & $B \vec{r}$ & & \\
\hline 1) 11 [1: & $B 7$ & & \\
\hline 01109 & 87 & & \\
\hline ந1 IA & $5 F$ & & \\
\hline ПIIEE & 1010 & & \\
\hline OIII: & E:D & $E F$ & 01 \\
\hline IIIF & 47 & & \\
\hline OIEO & $7 \mathrm{~B}$ & & \\
\hline ПIE1 & $E 6$ & $F O$ & \\
\hline П1E: & B̃̄ & & \\
\hline DIE4 & $5 F$ & & \\
\hline 01E5 & CI & EB & 01 \\
\hline O1EE & $5:$ & E.5 & 01 \\
\hline 01EB & cn & $A \bar{r}$ & 00 \\
\hline & FE & $\$ 0$ & \\
\hline
\end{tabular}

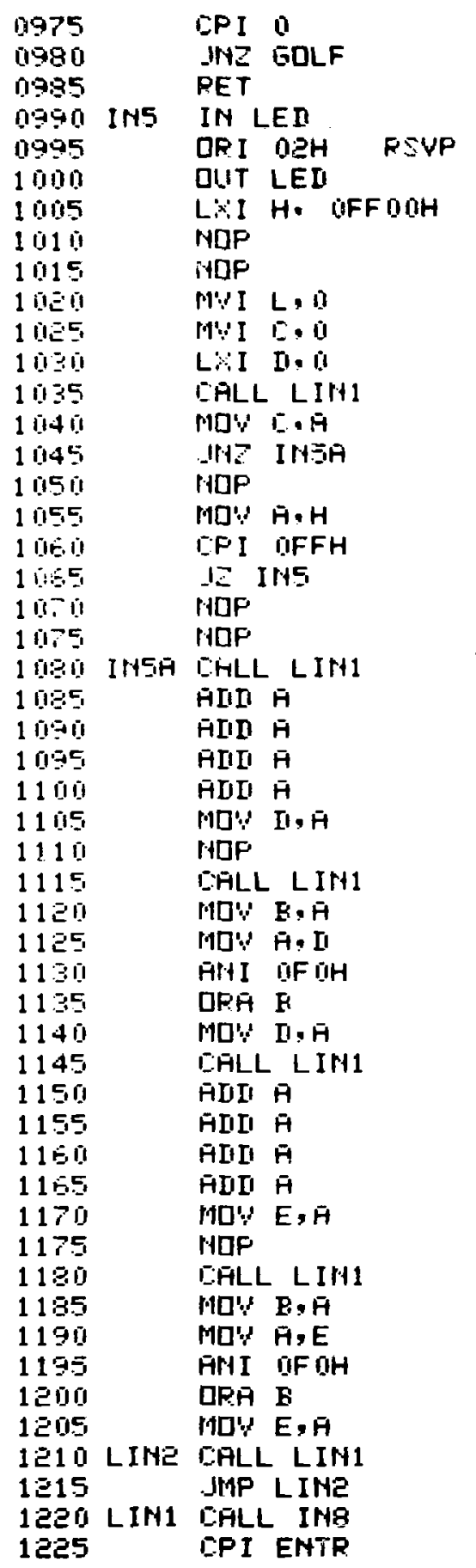




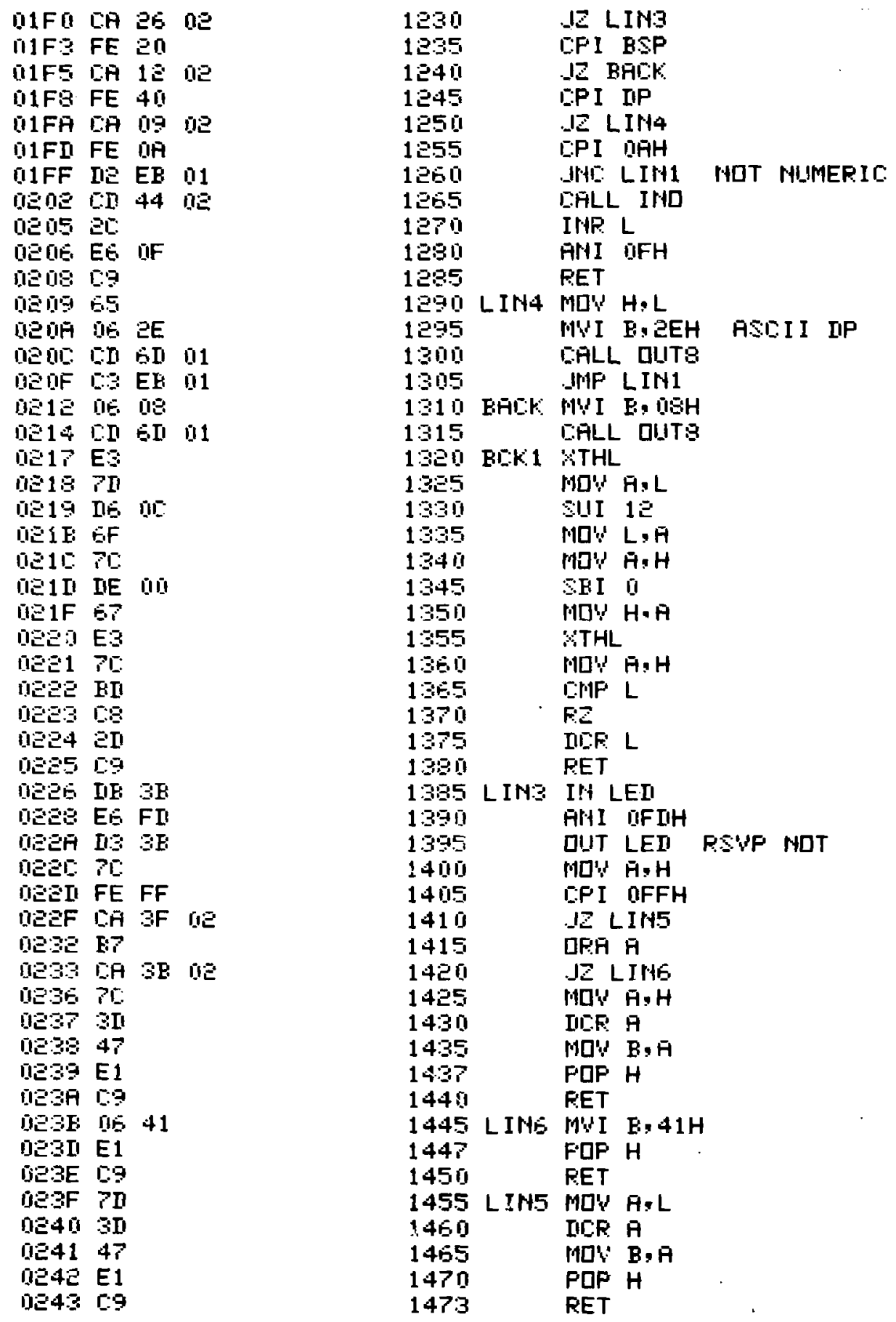


61

\begin{tabular}{|c|c|c|c|}
\hline $0=44$ & FE & 40 & \\
\hline 10246 & 62 & $4 E$ & प12 \\
\hline 0249 & 06 & ᄅE & \\
\hline $0 \geqq 4 \mathrm{~B}$ & 0.3 & 51 & 02 \\
\hline $034 E$ & 00 & 30 & \\
\hline 0250 & 47 & & \\
\hline $0=1$ & DII & EII & 01 \\
\hline 0ق:54 & 70 & & \\
\hline 9255 & 59 & & \\
\hline 0 105 & I1.5 & & \\
\hline 0057 & 4 & & \\
\hline 258 & 23 & & \\
\hline 0259 & 50 & & \\
\hline $025 \mathrm{~A}$ & 30 & & \\
\hline MESE & SE & & \\
\hline $0=5$ & 23 & & \\
\hline पㄷำ & EE & & \\
\hline DIESE & I1 & & \\
\hline 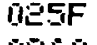 & 5 & & \\
\hline UESU & $4 E$ & & \\
\hline $0=1$ & $\begin{array}{l}23 \\
5 i\end{array}$ & & \\
\hline nב: & 3 & & \\
\hline nest & $5 E$ & & \\
\hline П토 & 20 & & \\
\hline DEES & 59 & & \\
\hline nEs? & 71 & & \\
\hline प068 & 3 & & \\
\hline ПอE & 72 & & \\
\hline 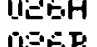 & 23 & & \\
\hline $\begin{array}{l}\text { MEE. } \\
\text { MEST }\end{array}$ & 3 & & \\
\hline ПЕ๐ & 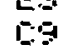 & & \\
\hline DEEE & 78 & & \\
\hline DEEFF & 41 & & \\
\hline ПЕР" & $4 F$ & & \\
\hline ดอ7 & EB & & \\
\hline 0อ7อ & $\mathrm{c9}$ & & \\
\hline $0 \sum 73$ & $E D$ & 60 & 미 \\
\hline ח공 & CD & 00 & al: \\
\hline 0279 & ZE & 0.5 & \\
\hline 르 & 79 & & \\
\hline ח1275: & $\mathrm{BP}$ & & \\
\hline ำำ & E.A & ED: & 0อ \\
\hline 280 & 78 & & \\
\hline 0อ31 & E6 & PF & \\
\hline nes3 & 67 & & \\
\hline Des4 & 79 & & \\
\hline & ES & 80 & \\
\hline 289 & 4 & $\in \mathrm{I}$ & 01 \\
\hline
\end{tabular}

\begin{tabular}{|c|c|c|c|c|}
\hline $\begin{array}{l}1475 \\
1480 \\
1485 \\
1490 \\
1495 \\
1500 \\
1505 \\
1510 \\
1515 \\
1580 \\
1585 \\
1580 \\
1595 \\
1540 \\
1545 \\
1550 \\
1555 \\
1550 \\
1565 \\
1570 \\
1575 \\
1530 \\
1585 \\
1590 \\
1595 \\
1500 \\
1505 \\
1510 \\
1615 \\
1680 \\
1685 \\
1630 \\
1695 \\
1640 \\
1645 \\
1650 \\
1655 \\
1660 \\
1605 \\
1650 \\
1675 \\
1680 \\
1685 \\
1690 \\
1695 \\
1700 \\
1705 \\
1710 \\
1715 \\
1750 \\
1725\end{array}$ & $\begin{array}{l}\text { QUTH } \\
\text { QUTE } \\
\text { QUTE }\end{array}$ & 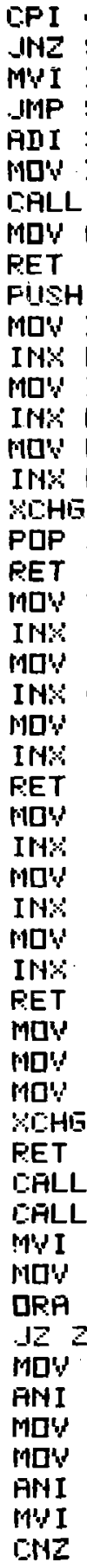 & 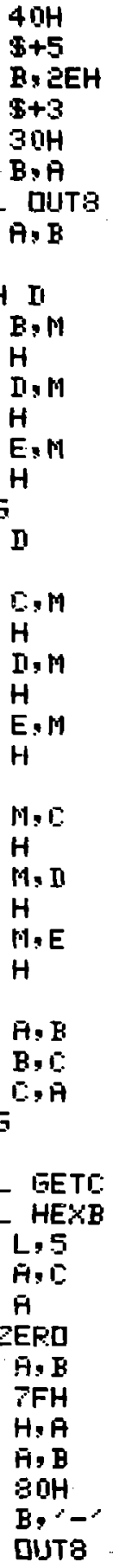 & $\begin{array}{l}\text { GET IATA } \\
\text { MAKE BCD } \\
\text { \# QF MIEITS }\end{array}$ \\
\hline
\end{tabular}




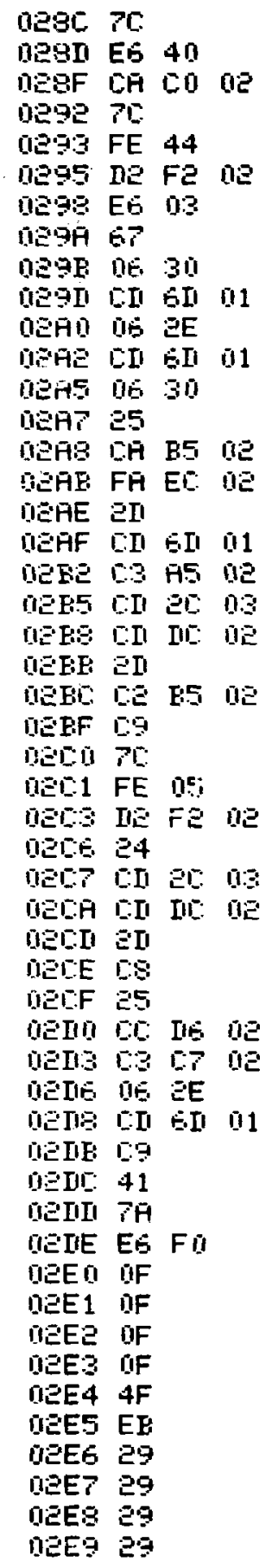

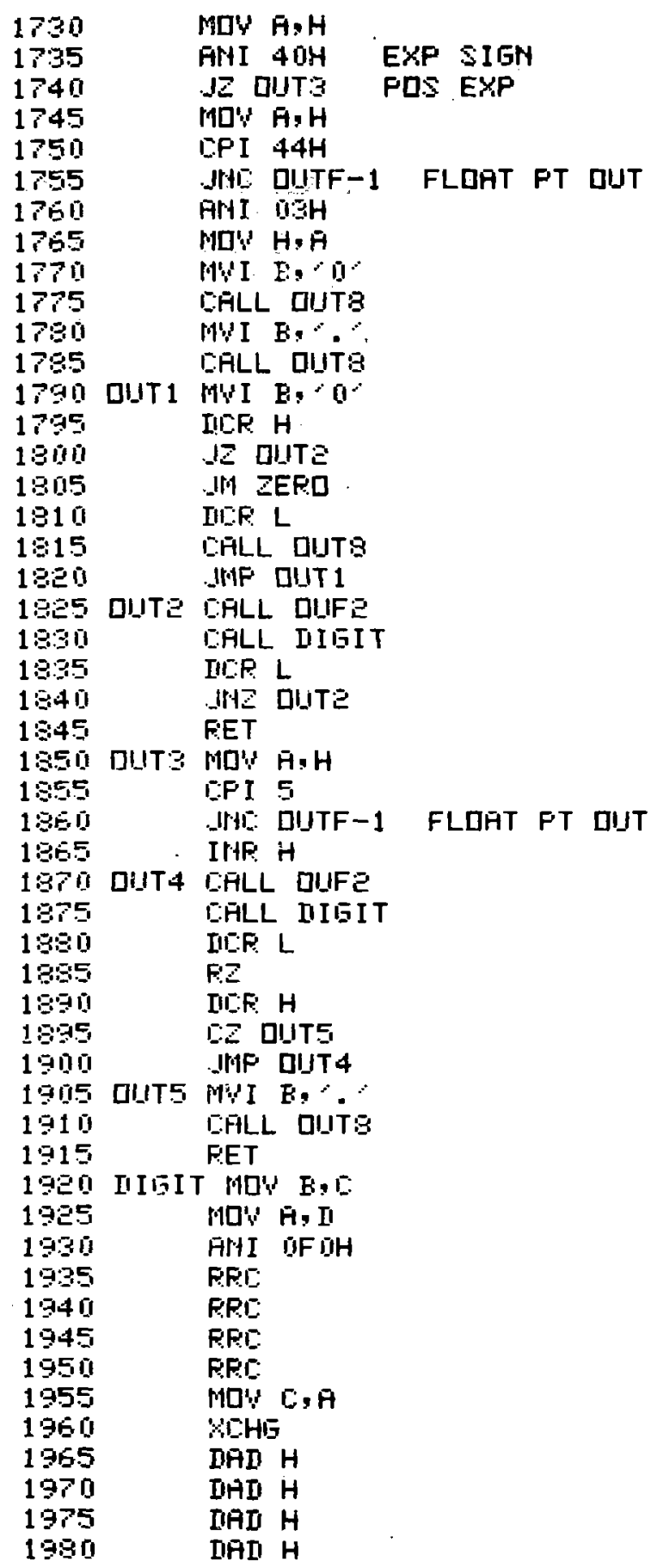




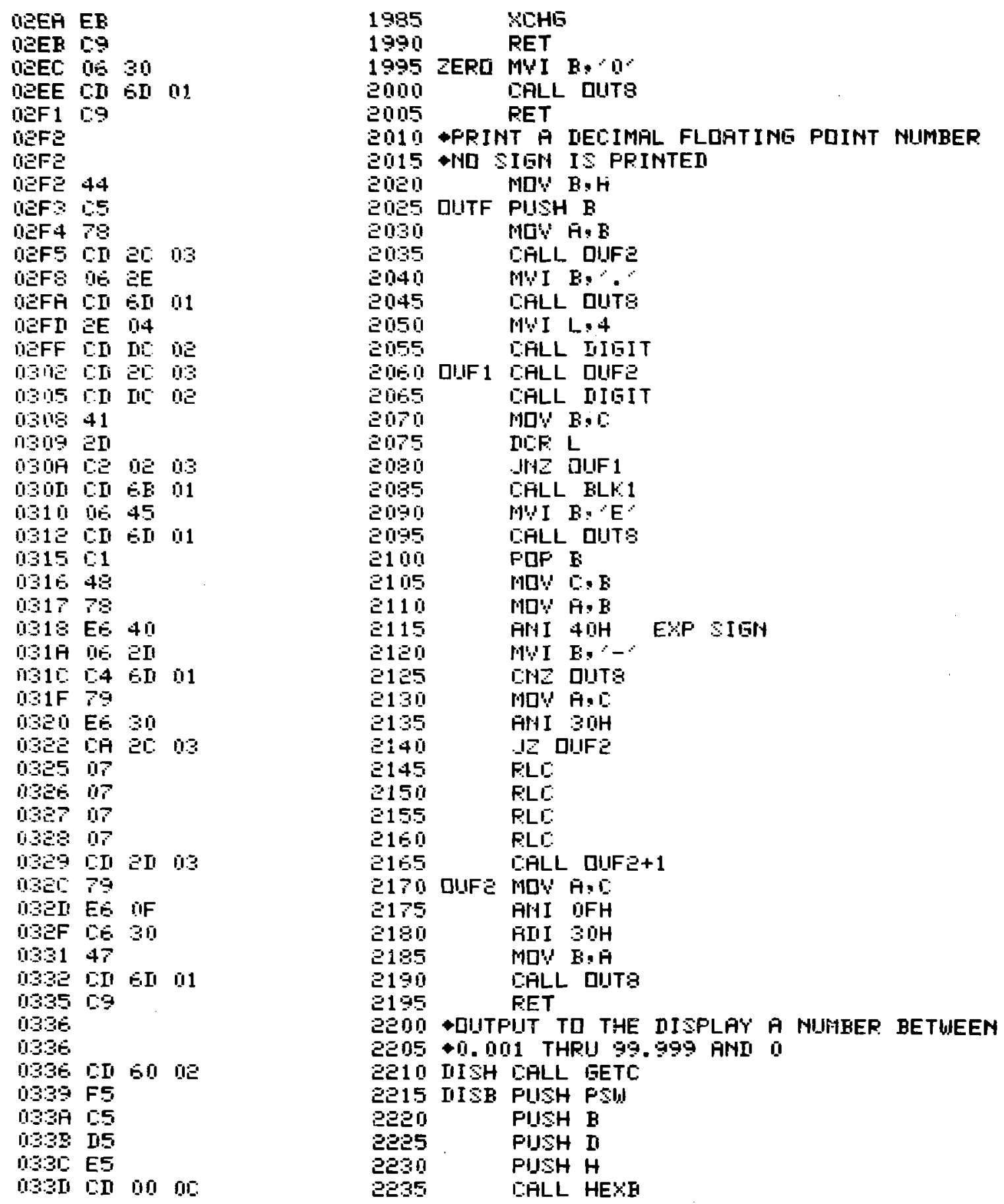




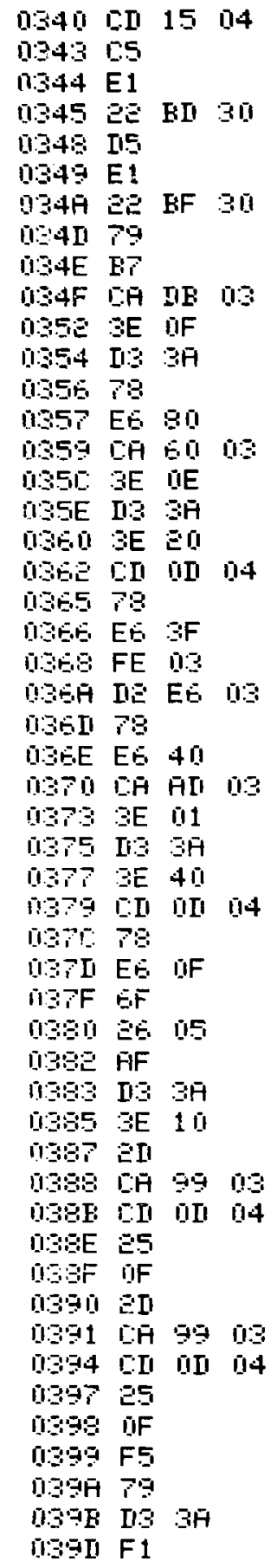

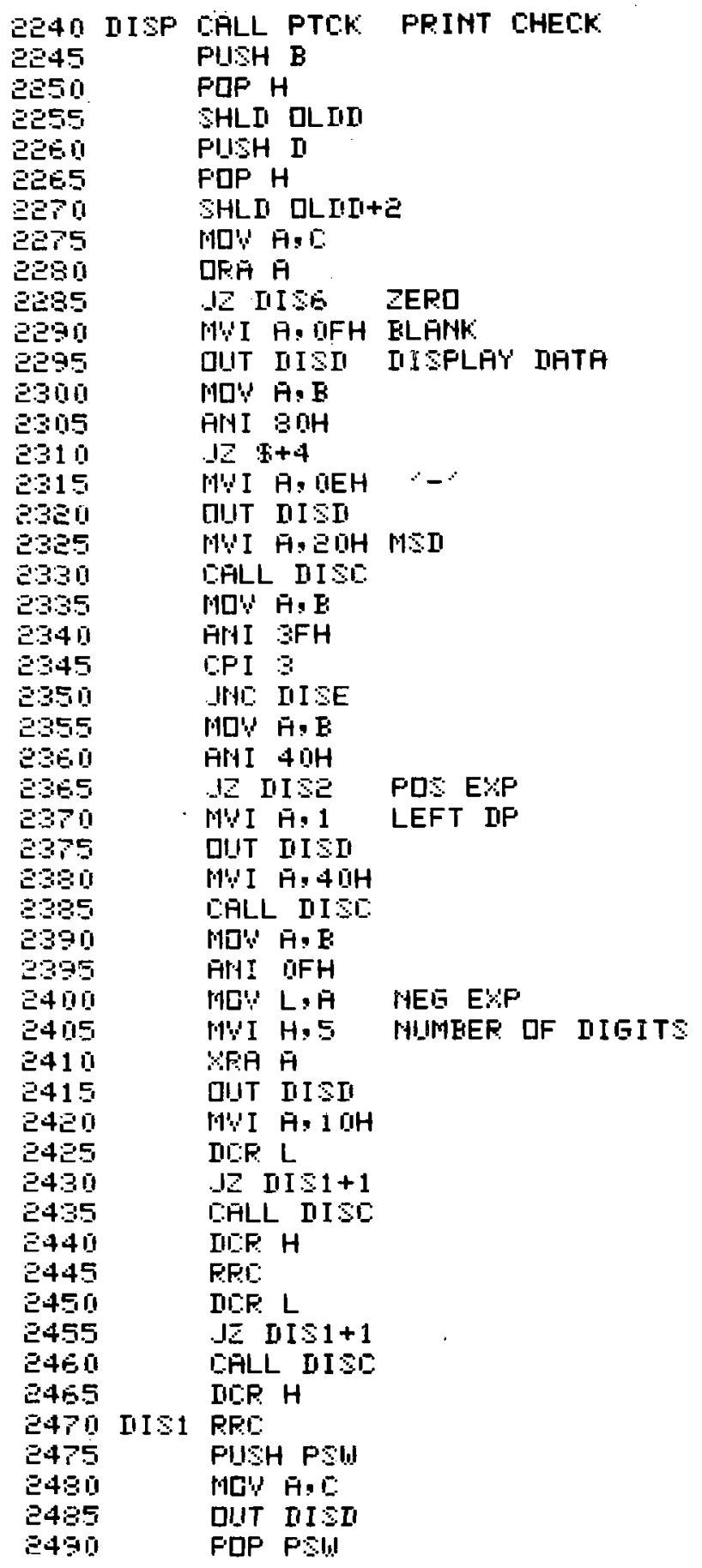




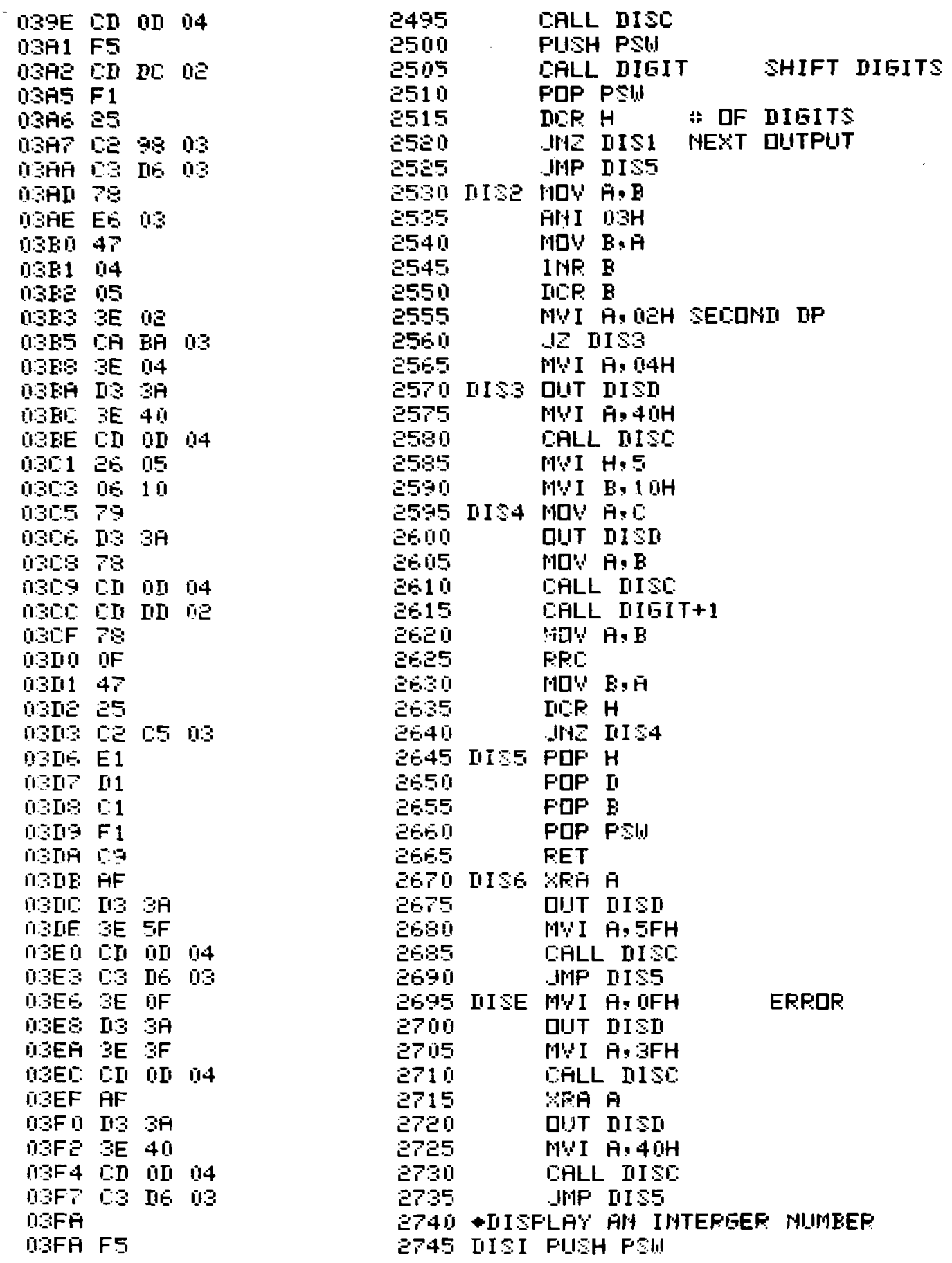




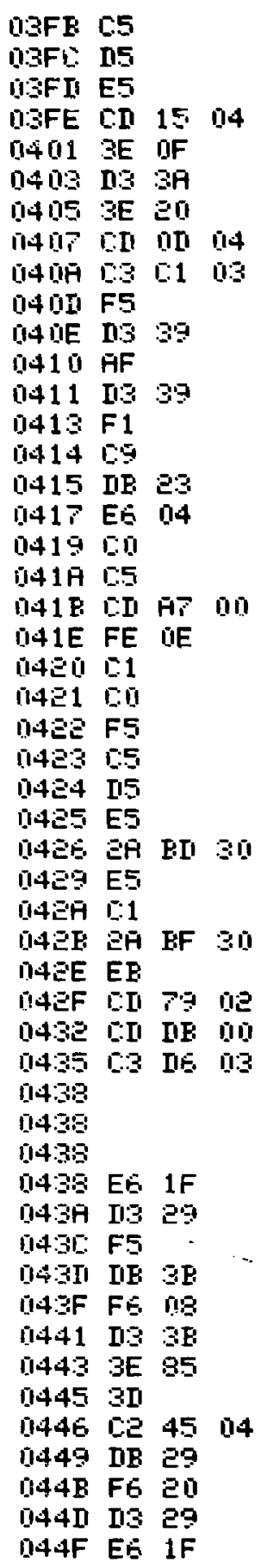

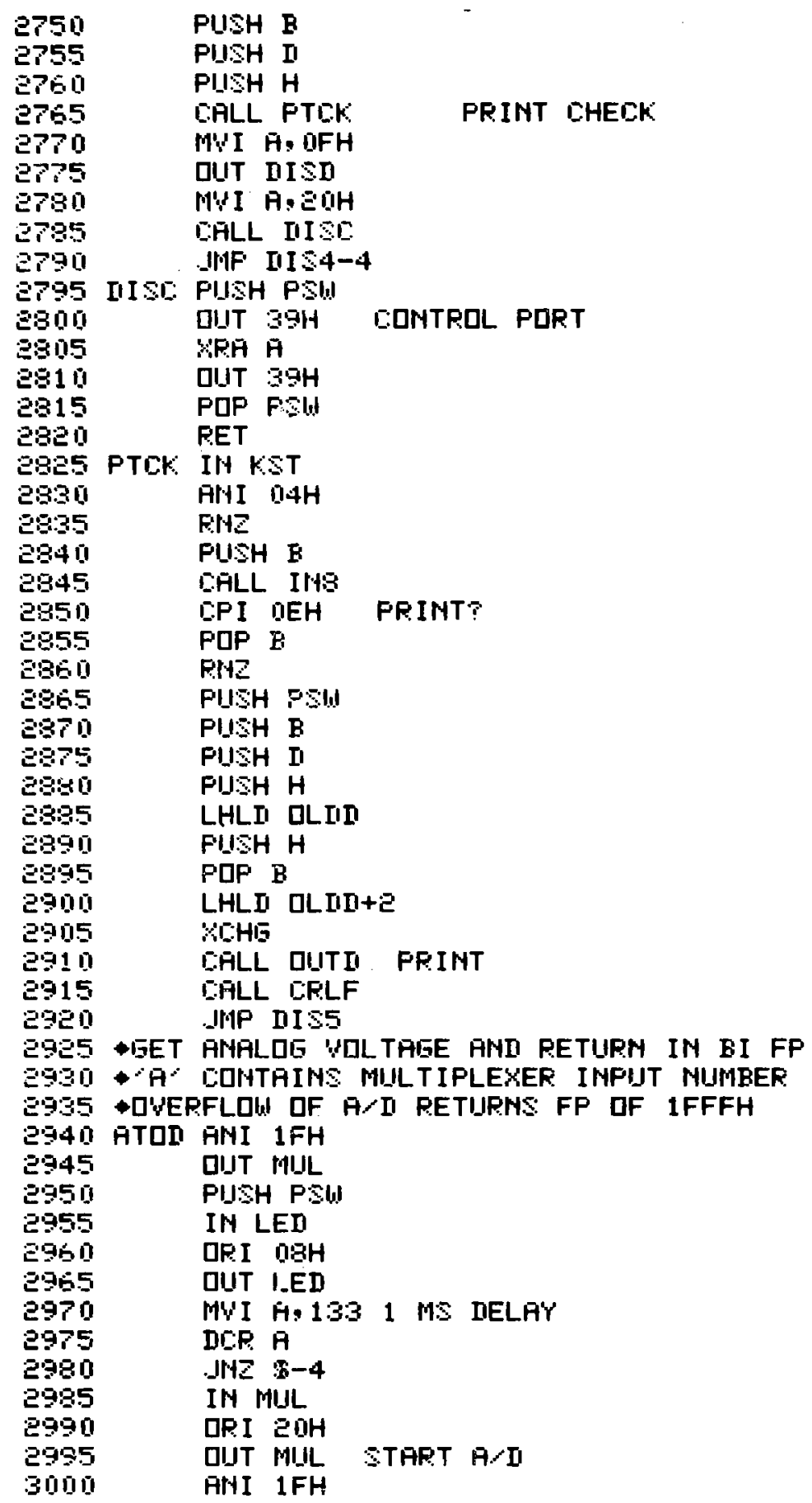

2750

2755

2760

구온

궁ำ

27?5

E780

2735

อ7ดั

อ795

230i

$3 \Xi 05$

료 11

2315

2820

EBes PTCK

23:34

로요

2840

2845

2850

2855

Eงด

8965

루이

ears

टxष

23:5

Eख9ด

E:

29010

2905

2910

2915

르음

2925

E900

E955

2940

2945

2950

2955

2960

2965

2970

2975

2980

2985

2990

2955

3010

PUSH B

PUSH II

PIISH H

CALL PTEK PRINT EHECK

MUI A. OFH

DUT DISI

MUI A, EIIH

CALL IIISE.

INF III $>4-4$

IIISI PIISH PSU

UIT 39H EOMTROL PORT

YRA $A$

पUT $39 \mathrm{H}$

PUP FSU

RET

PTCK IN KST

AlH $04 \mathrm{H}$

Fit?

FUSH B

CALL IHB

CPI DEH FRINT?

POP E

PFIZ

PUSH PSW

PIISH B

PIJSH II

PIJSH H

LHLII QLIII

Fils $H$

PDF B

LHLI GLIID+2

XCHIS

EFLL DUITII FFINT

GALL CELF

.MAP IIS5

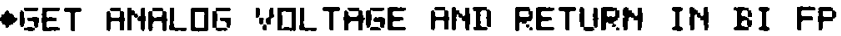

- $A$ coltTAINS MILLTIPLEXER IMFIJT MUMBER.

- D'VEPFLUW DF $A / I$ RETIJPNS FP DF IFFFH

ATOD ANI 1FH

QUIT IIIJ

PUSH PSU

IN LED

OR I $\mathrm{OBH}$

DUT I.ED

MVI H. 133 1 MS NELA'

DCP $A$

INIZ $8-4$

IN MUL

पPI $\mathrm{EOH}$

DIJT MIL STAPT A $\angle I$ 
0451 ก3 29

0453 nE 32

0455 EE 40

10457 C:A $53 \quad 04$

IISSÄ IIE BE

I. 450 ES 20

OUSE CA EA 04

045111 FF IF

046401 010 00

04E

046A IIE 32

D4EE ES 10

OUSE IEA $\quad 97 \quad 04$

OIT1 IIE $3 \mathrm{E}$

1147s $\mathrm{EF}$

11474 EG OF

11475 57

U477 IIE 31

1.47\% $\mathrm{EF}$

DIUTA $5 F$

IITE CII $3:$ IIE

U4TE IIE: 32

14:30 15

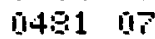

1048 07

IIS3 EE BU

11485 $\mathrm{E} 1$

litis $4 \mathrm{~F}$

0407 กิ 78

1.4: 21 FI: EF

IU⿴囗十 III EL DF

OLSF IE $\mathrm{BE}$

$0491 \mathrm{ES} F$

11493 IIS $\mathrm{SB}$

$0495 \mathrm{~F} 1$

0496.99

11497 IIE 3

049 EE UF

$049 \mathrm{E} 5$

049: IE 31

O4GE IOS PA II4

I. $4 \mathrm{H} 1$

IIAT1

$\overline{1}+\bar{H} 1$

14A1

$04 \mathrm{~A} 1$

$0441 \quad 32 \quad 85 \quad 30$

$04 \mathrm{AH}$ CI $97 \mathrm{IF}$

$04 A T$ 巳1 BE 30

DAAA ED 67 OD

OAAR SE OA

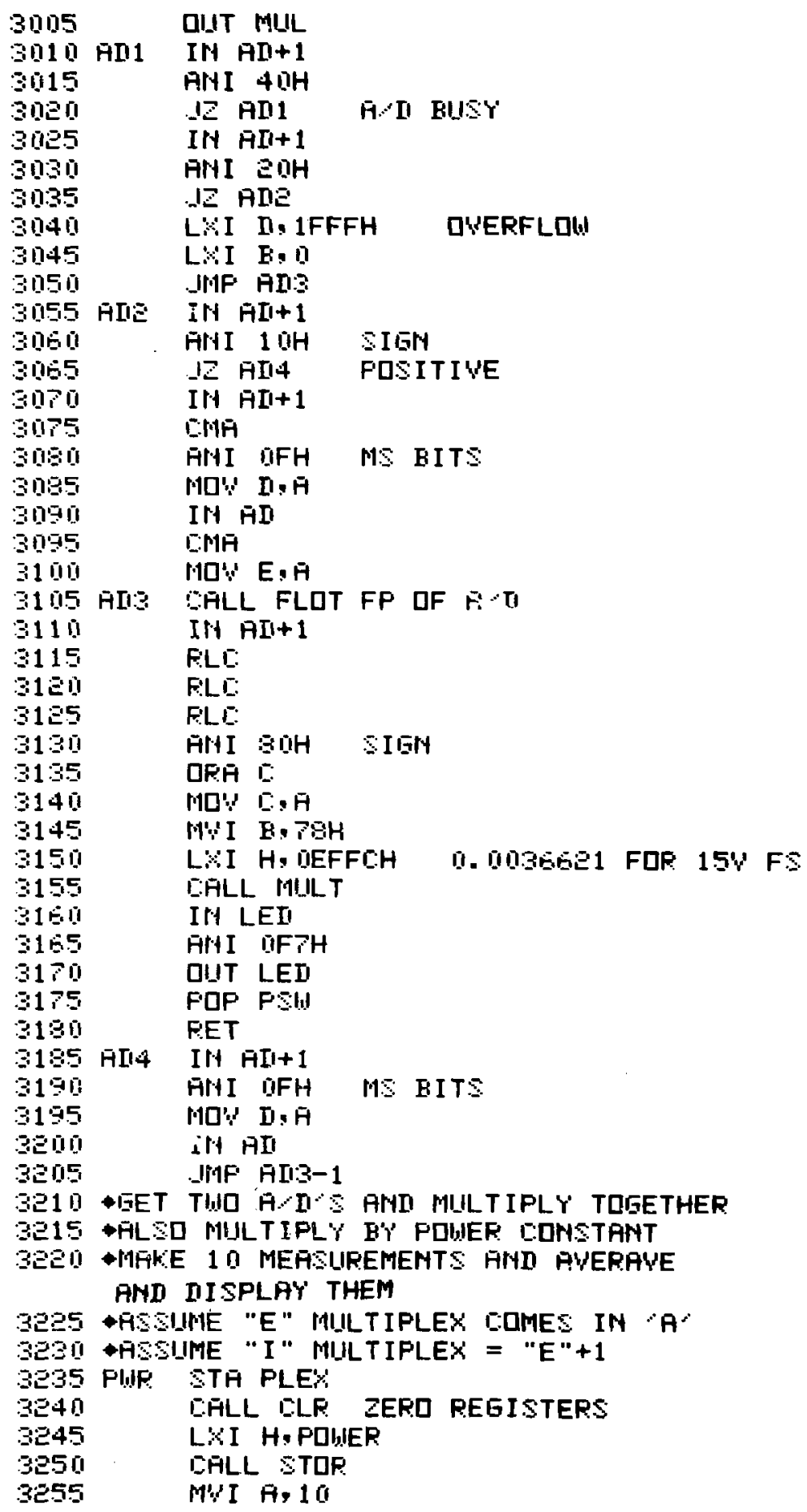




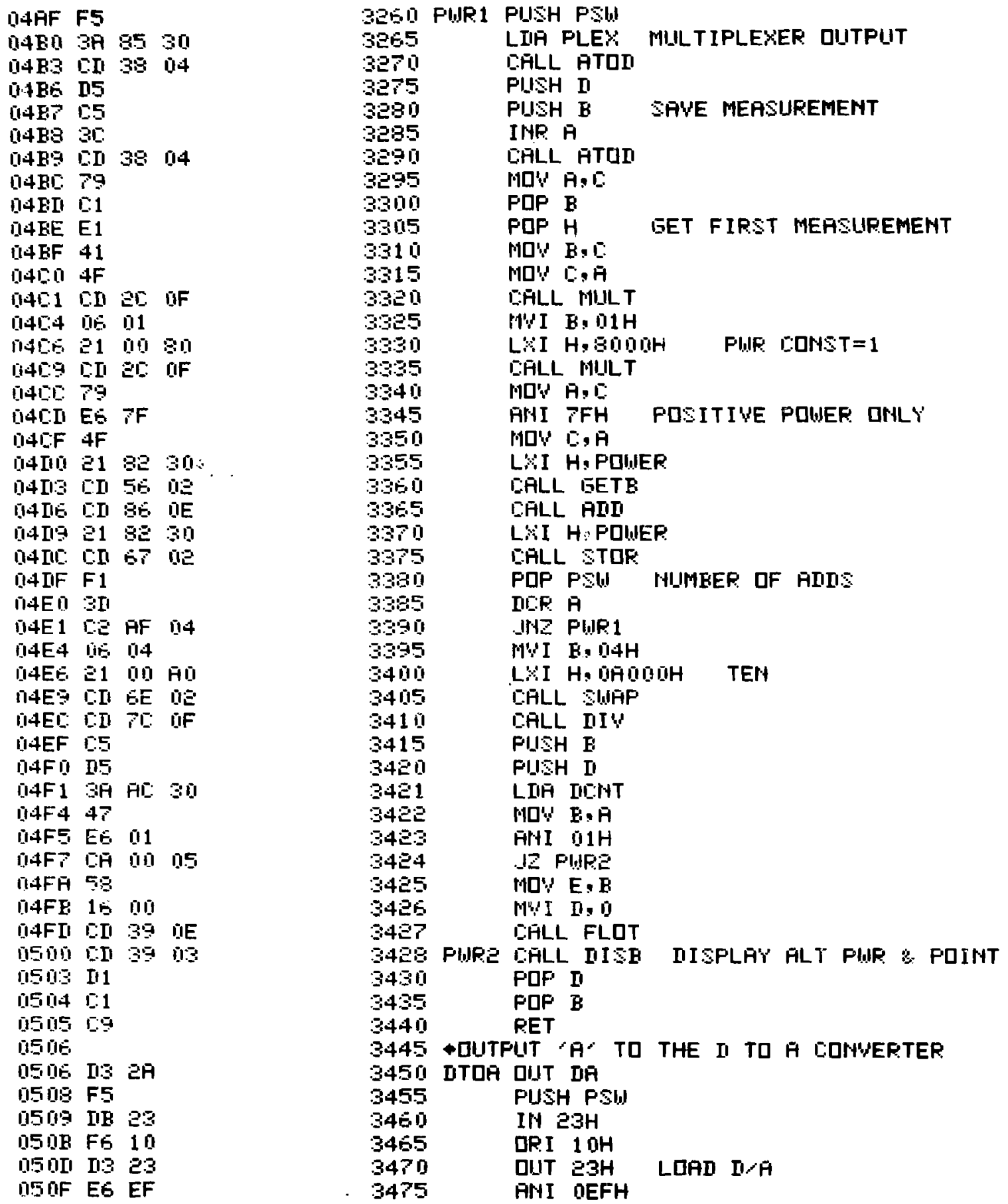




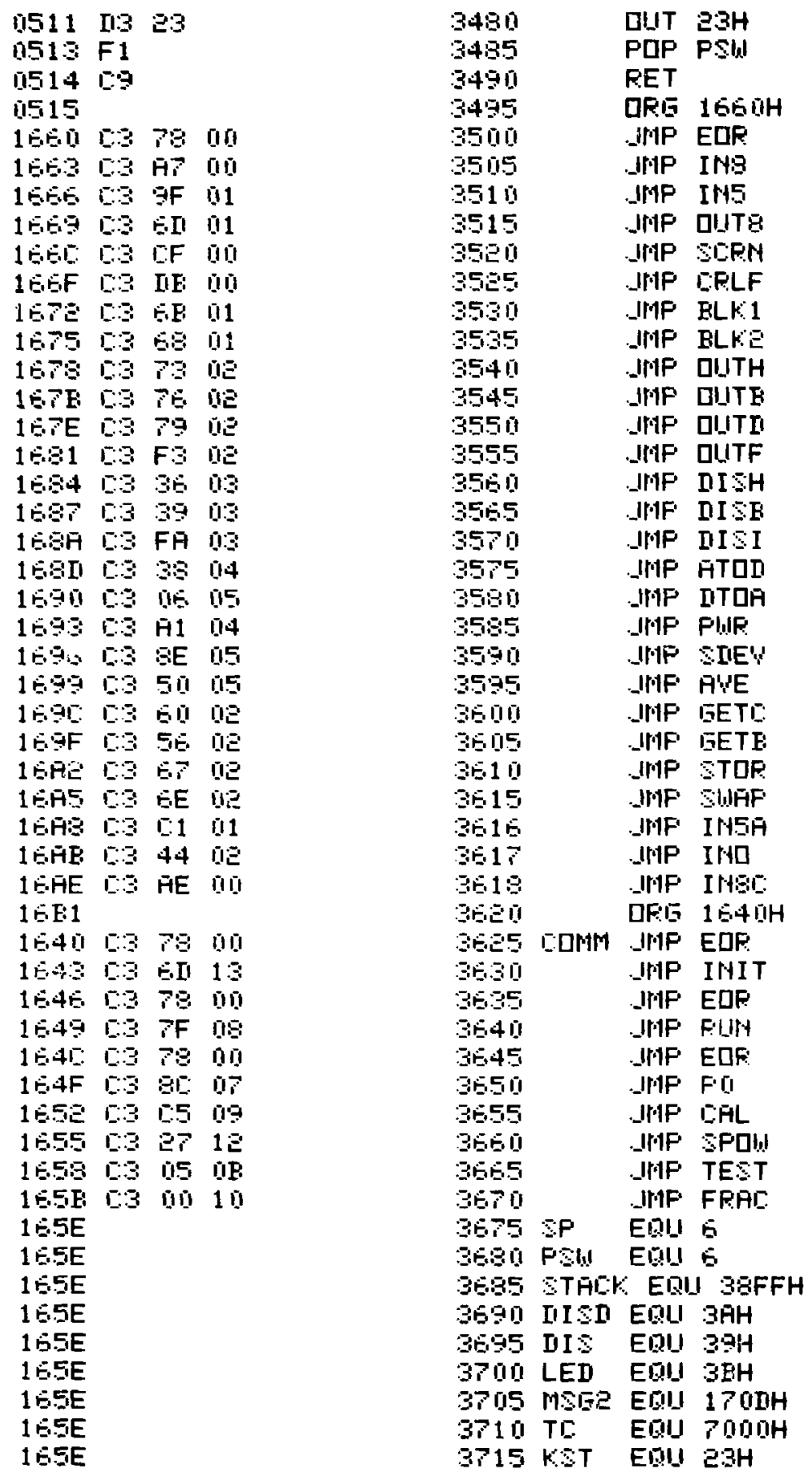




$$
\begin{aligned}
& 1 \mathrm{ESE} \\
& 1 \text { E.SE } \\
& 16.5 \mathrm{E} \\
& 165 \mathrm{E} \\
& 16.5 \mathrm{E} \\
& 1 \mathrm{SE} \\
& 1 \mathrm{E} . \mathrm{EE} \\
& 15.5 \mathrm{E} \\
& 165 \mathrm{E} \\
& 16.5 \mathrm{E} \\
& 165 \mathrm{E} \\
& 1 \mathrm{EE} \\
& 1 \mathrm{ESE} \\
& 165 \\
& 15.5 \mathrm{E} \\
& 15.5 \mathrm{E} \\
& 15 \mathrm{SE} \\
& 16.5 \mathrm{E} \\
& 155 \\
& 16.5 \mathrm{E} \\
& 155 \mathrm{E} \\
& 165 \mathrm{E} \\
& 16.5 \mathrm{E} \\
& 165 \mathrm{E} \\
& 16 \mathrm{E} \\
& 16.5 \mathrm{E} \\
& 165 \mathrm{E} \\
& 1 \mathrm{BSE} \\
& 16.5 \mathrm{E} \\
& 15.5 E \\
& \text { 1E.5E }
\end{aligned}
$$

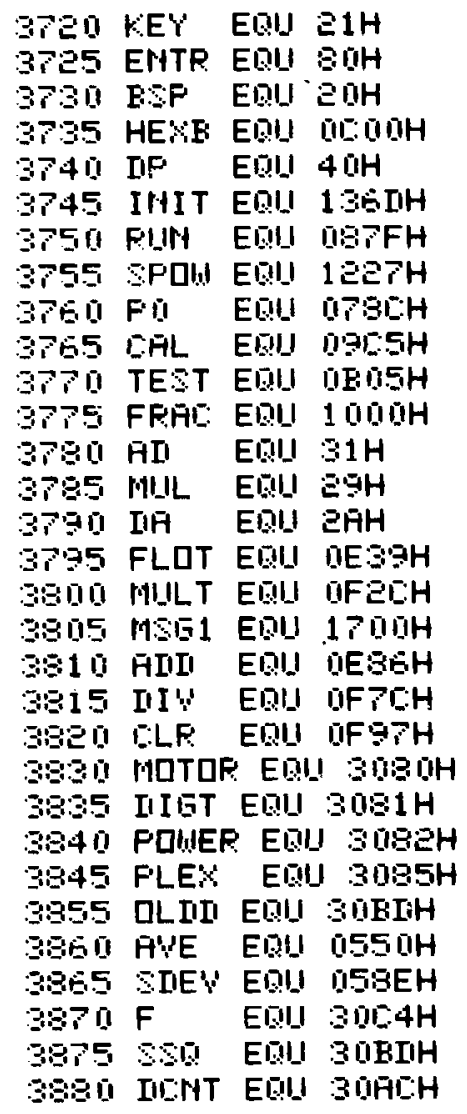


0.550

0.550

i.5.5.

0.550 EA 37 30

0.55323

01554 ह2

$0557 \quad 01 \quad 300$

ISSE EI GF $1 \mathrm{E}$ DSSI EI ES DE DSE $21 \quad 90$ DSE 15E 21 BF 30

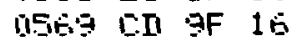
DISE DE 80 GE DISEF 21 BF 30

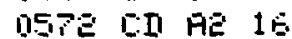
0.5.5 21 at 30 0.58 D.I GE 15 DSTE EII $2 E$ DE OISTE $\Xi 1$ GE 30

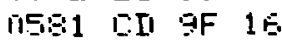
01534 LI BE IE 0507 ¿1 $92 \quad 30$ TSEA EII AE 16 0.5I 19

D.5:E

$0.5 \mathrm{E}$

IISGE

IISEE

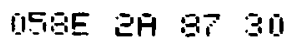
Dิ5:-1 ER

त5GE LI 39 DE $0595 \quad 21 \quad 95 \quad 30$ 0598 II AE 15 015G 21 BF 30 UISGE CII GF 15 DSE1 EII $7 \mathrm{O}$ OF

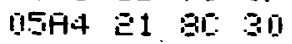
DSAT EII AE 16 IISATA CII EB OE DSAII $21 \quad 9530$ USE IOI $9 F$ 16 IISES EI ED OIF NISEE $21 \quad 95 \quad 30$ NSEG EII AE 15 DSEL: 21 BL 30 IISEF ID 16 1152 $21 \quad 3930$

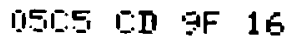
प.5. $\mathrm{CD} \quad 33$ aE $\begin{array}{llll}\text { DILE } & 31 & 04 & 30\end{array}$ पIEE ID OF 15 USIII EI 20 OF IISIl4 $21 \quad 98 \quad 30$ DSIIP CII AE 16 DSEIA EA $87 \quad 30$ USIII $\Xi E$

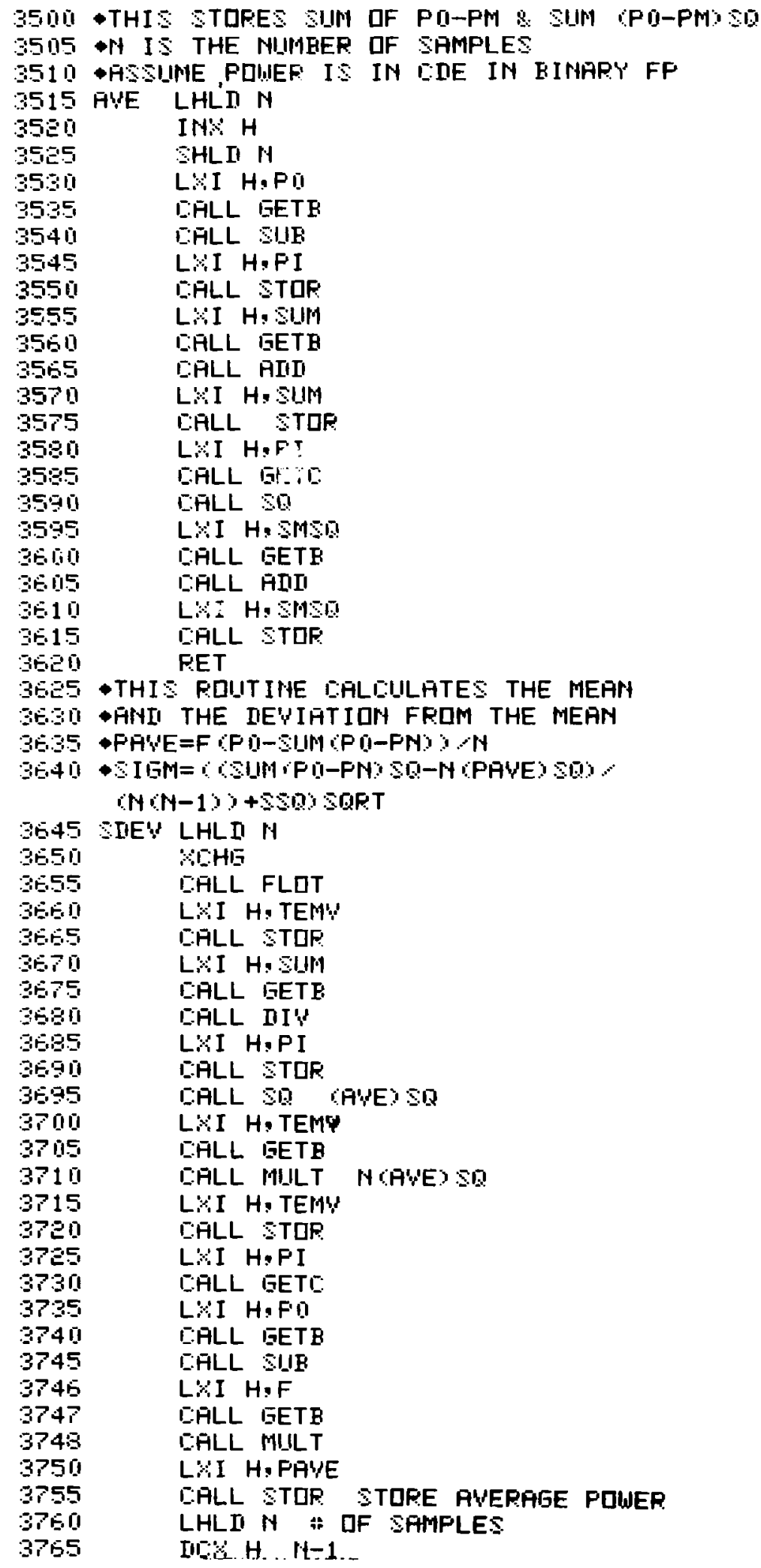




\begin{tabular}{|c|c|c|c|}
\hline $05 \mathrm{NE}$ & EB & & \\
\hline $65 \mathrm{IF}$ & EI & 39 & OEE \\
\hline $15 \mathrm{E} 2$ & 21 & $9 B$ & 30 \\
\hline $15 E 5$ & $\sin$ & $\mathrm{AP}$ & 16 \\
\hline $15 E 8$ & EA & 87 & 30 \\
\hline USER & $\begin{array}{l}\text { EB } \\
\text { Cn }\end{array}$ & 39 & IIE \\
\hline 1ิ5EF & 21 & $9 \mathrm{~B}$ & 30 \\
\hline $0.5 F 2$ & CI & $G F$ & 16 \\
\hline $0.5 F 5$ & En & 20 & UF \\
\hline $05 F$ & 21 & $9 B$ & 30 \\
\hline $05 \mathrm{FB}$ & EI & $\overline{A E}$ & 15 \\
\hline $015 \mathrm{FE}$ & 21 & 90 & 30 \\
\hline 0601 & EII & $91:$ & 16 \\
\hline 1004 & 21 & 95 & 30 \\
\hline $0<07$ & EII & $9 F$ & 18 \\
\hline QS⿴囗十 & E: & 83 & $\mathrm{DE}$ \\
\hline QE & $\mathrm{e} 1$ & $9 \mathrm{~B}$ & 30 \\
\hline 01010 & EII & $G F$ & 16 \\
\hline 0613 & $E I$ & $\mathrm{H} 5$ & 16 \\
\hline 1015 & $E I$ & 75 & $\mathrm{OF}$ \\
\hline UE & 21 & $\approx 1$ & 30 \\
\hline 10 & E.n & $9 F$ & 16 \\
\hline $0 \mathrm{E}$ & E.II & 845 & IIE \\
\hline ดBe? & EII & $E 3$ & an \\
\hline 몬.5 & $\Xi 1$ & 98 & 30 \\
\hline 008 & EII & $\mathrm{HE}$ & 16 \\
\hline $\begin{array}{l}\text { DE:EE } \\
\text { DE:ED: }\end{array}$ & 5 & & \\
\hline UBẼ & IIE: & $3 \mathrm{E}$ & \\
\hline MEEE & FB & Eu & \\
\hline DE: & II: & $\Xi \mathrm{E}$ & \\
\hline 0135 & $\mathrm{EH}$ & $G E$ & 30 \\
\hline 1065 & 50 & $4 A$ & 16 \\
\hline$n=38$ & IIE & 30 & \\
\hline IESH & 11 & $\mathrm{BE}$ & 58 \\
\hline 0501 & E: & & \\
\hline $\begin{array}{l}\text { DEEE } \\
\text { DESF }\end{array}$ & $E 3$ & & \\
\hline $\begin{array}{l}\text { प5:35 } \\
0.40\end{array}$ & $1 \mathrm{E}$ & & \\
\hline ํㅣㄴ. 41 & $\mathrm{E}$ & & \\
\hline 0442 & $E$ & $3 \mathrm{I}$ & DE. \\
\hline 10.5 & nII & & \\
\hline 10.45 & $E 2$ & IH & $\pi$ \\
\hline 10.49 & $\Xi \mathbf{E}$ & & \\
\hline IB:AA & ES & & \\
\hline GE.4E: & EF & & \\
\hline 11540 & EII & $\overrightarrow{\mathrm{A}} \overrightarrow{\mathrm{r}}$ & OII \\
\hline $04 \mathrm{~F}$ & $\mathrm{O}$ & DF & \\
\hline 16.51 & $3 E$ & $F O$ & \\
\hline 015.5 & $\mathrm{BE}$ & & \\
\hline $\begin{array}{l}115.54 \\
115.5\end{array}$ & $\begin{array}{l}58 \\
00\end{array}$ & $9 A$ & 1 \\
\hline 0158 & E1 & & \\
\hline 05.59 & 70 & & \\
\hline
\end{tabular}

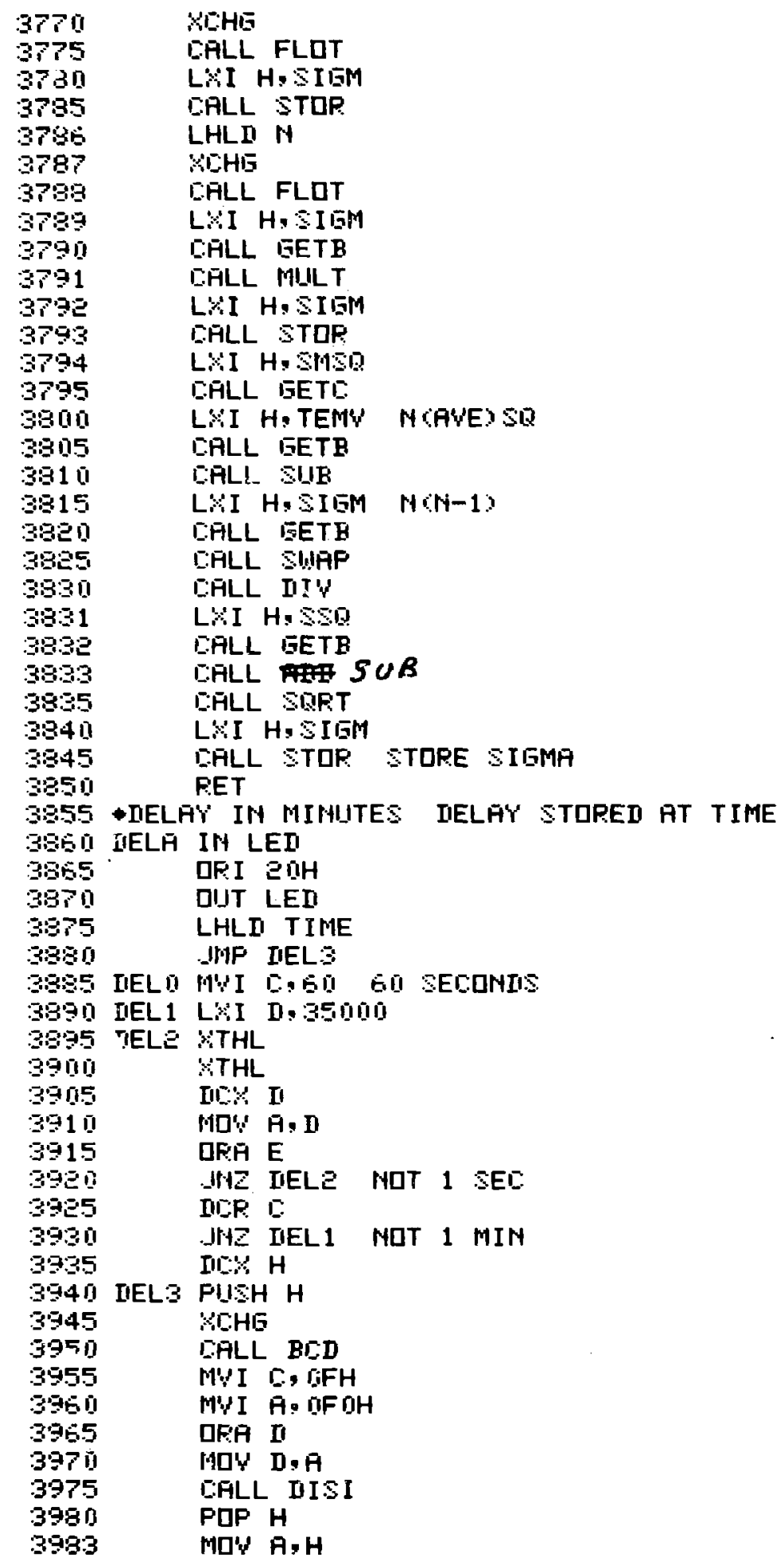




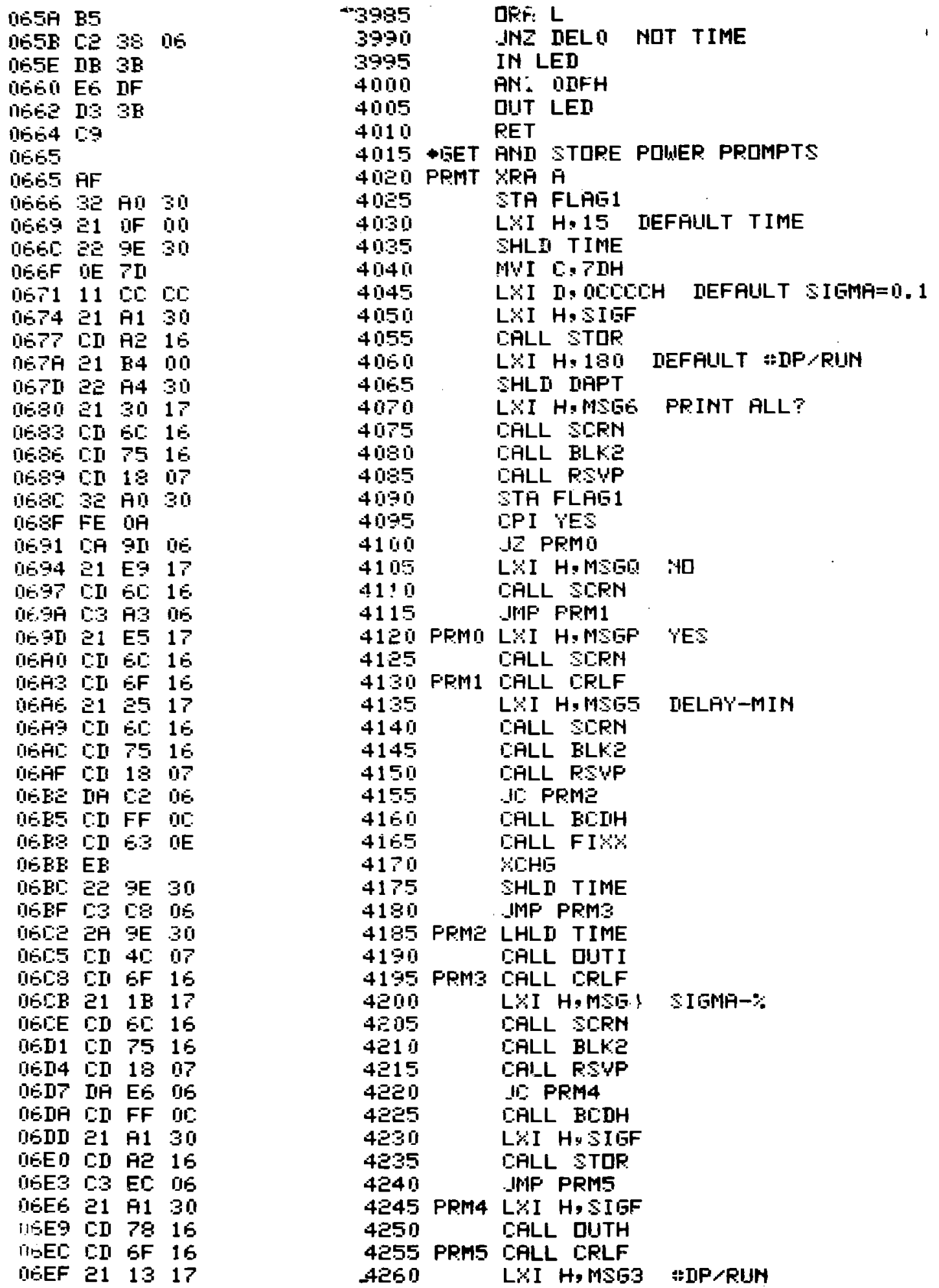


UBFE EI EC 16

USF5 대 7516

DEFB CII IS 07

OSFR DA OB 07

USFE CD FF OC:

0701 CI 63 DE

$0704 \mathrm{~EB}$

0705 02 H4 30

070 030311 0?

पिO

DTUE EI 4C OP

0711 CD SF IS

0714 C:I 6F 16

ดि17 0

0719 DE $9 \mathrm{E}$

DIAA FE DE

OTIC IIO $3 \mathrm{E}$

OIIE 11 पIU जU

ดTE1 EI 63 16

நITE4 FE GH

पก๊e 37

DTEP IOA 43 OT

GTEA FE 80

MTES 37

जTEI DEA 43 ar

0730 $31 \quad 41$ ดे

$073 \mathrm{ES}$

0734 III AE 18

07: $4 \mathrm{~F}$

0798 21 a1 FF

07SE 11 010

DTSE DS AB $1 E$

जiत4 $3 \overrightarrow{7}$

만 $\mathrm{SF}$

$074 \mathrm{~F} 5$

0744 IIE $3 \mathrm{E}$

DT 4E EE FII

074: IIS $3 \mathrm{E}$

DTि4A F1

0T4E $1: 9$

जT 4E: EE

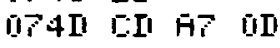

ด750 EE

प1951 70

마달 $\mathrm{EF}$

$0753 \quad 1557$ 0?

ดTSE 65

0757 T

0758 of

0759 OF

07SA OF

075E OF

DTSE EG OF

OTSE FG 30

076047

VIG1 CD 6916

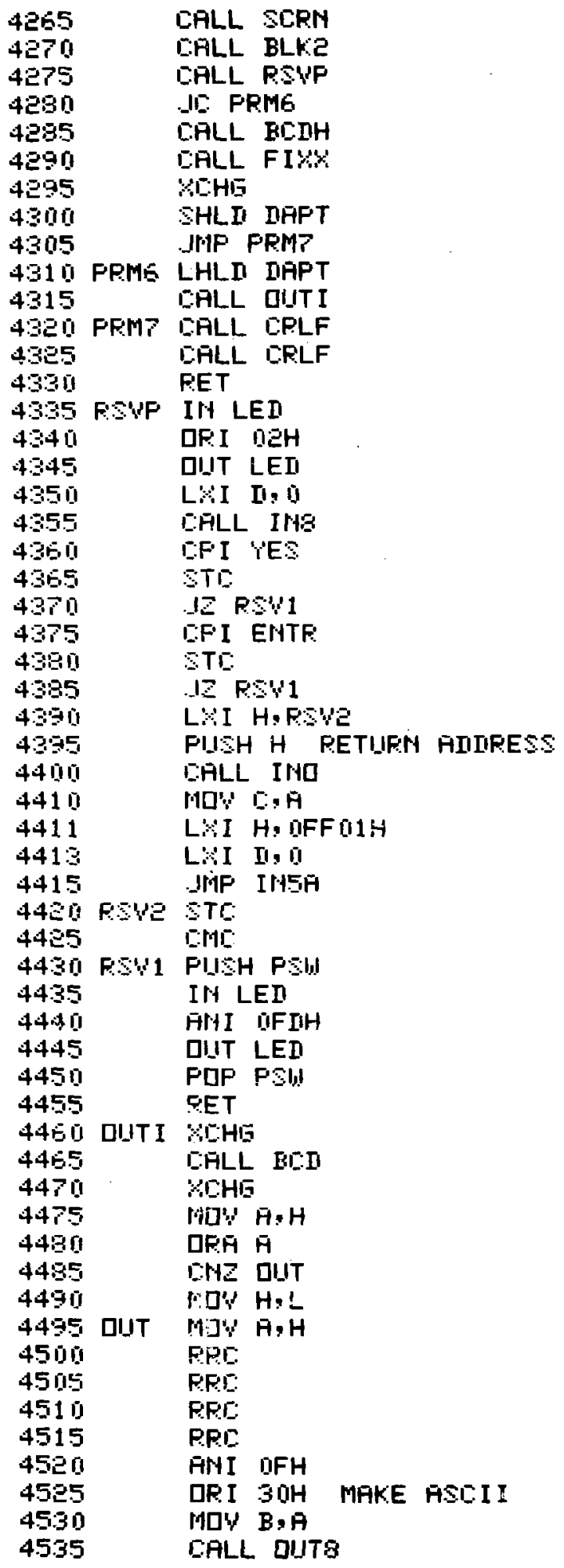




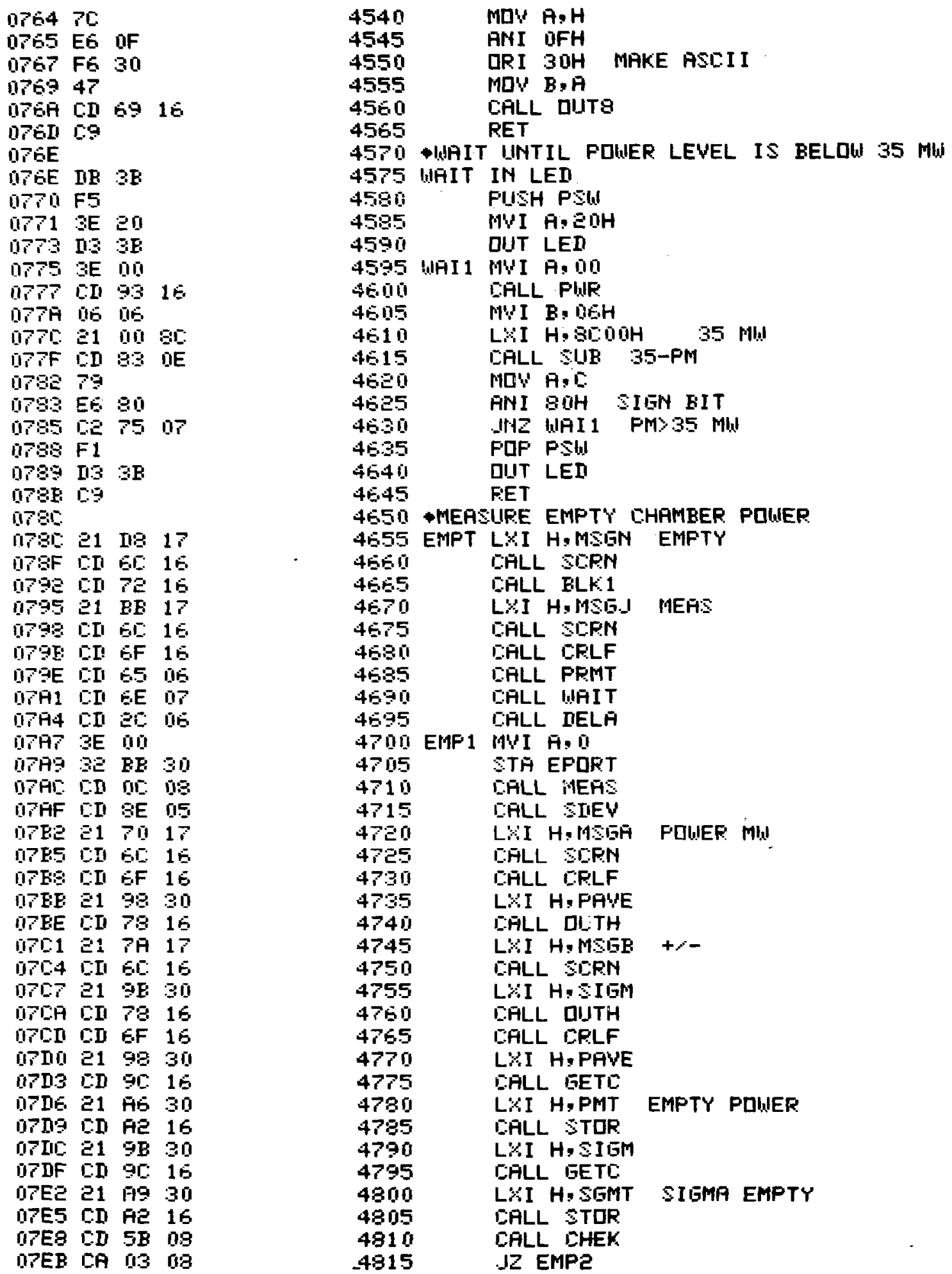




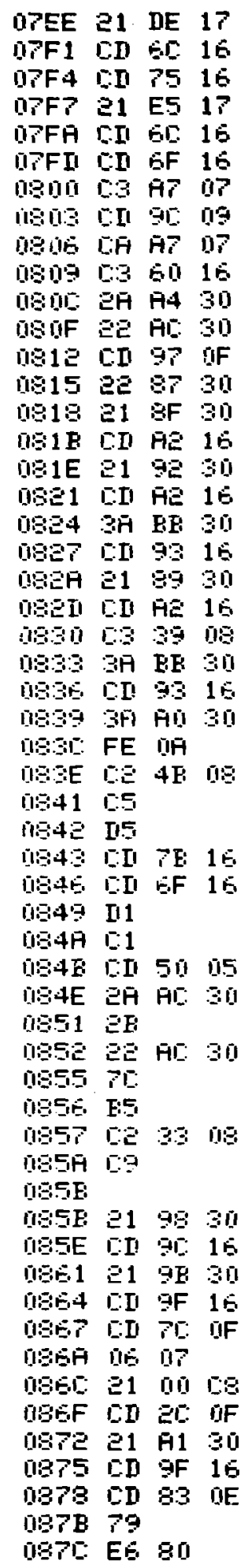

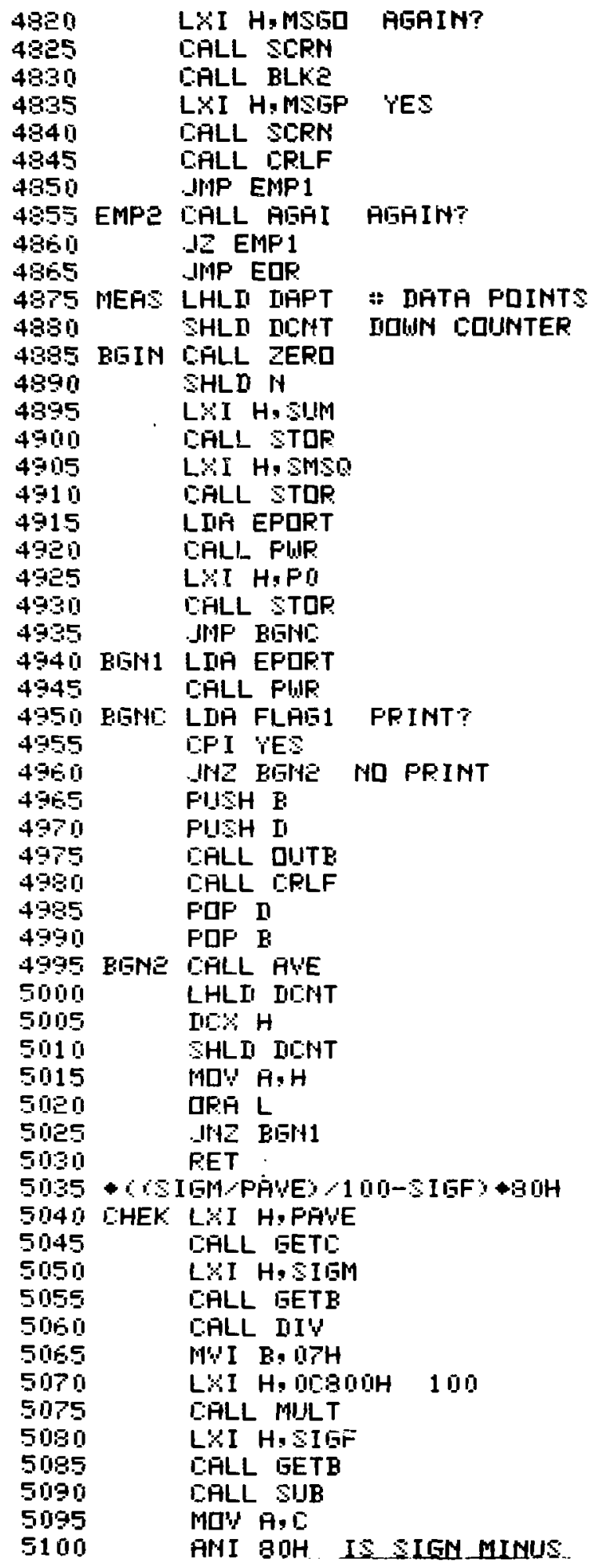




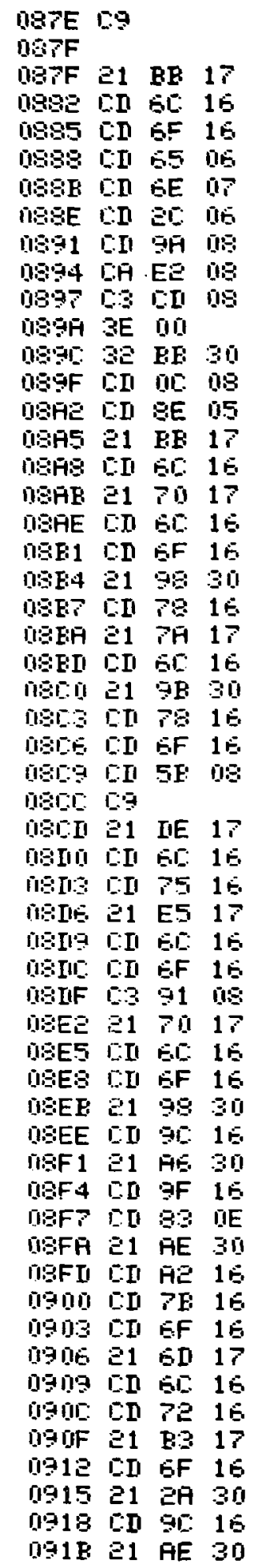

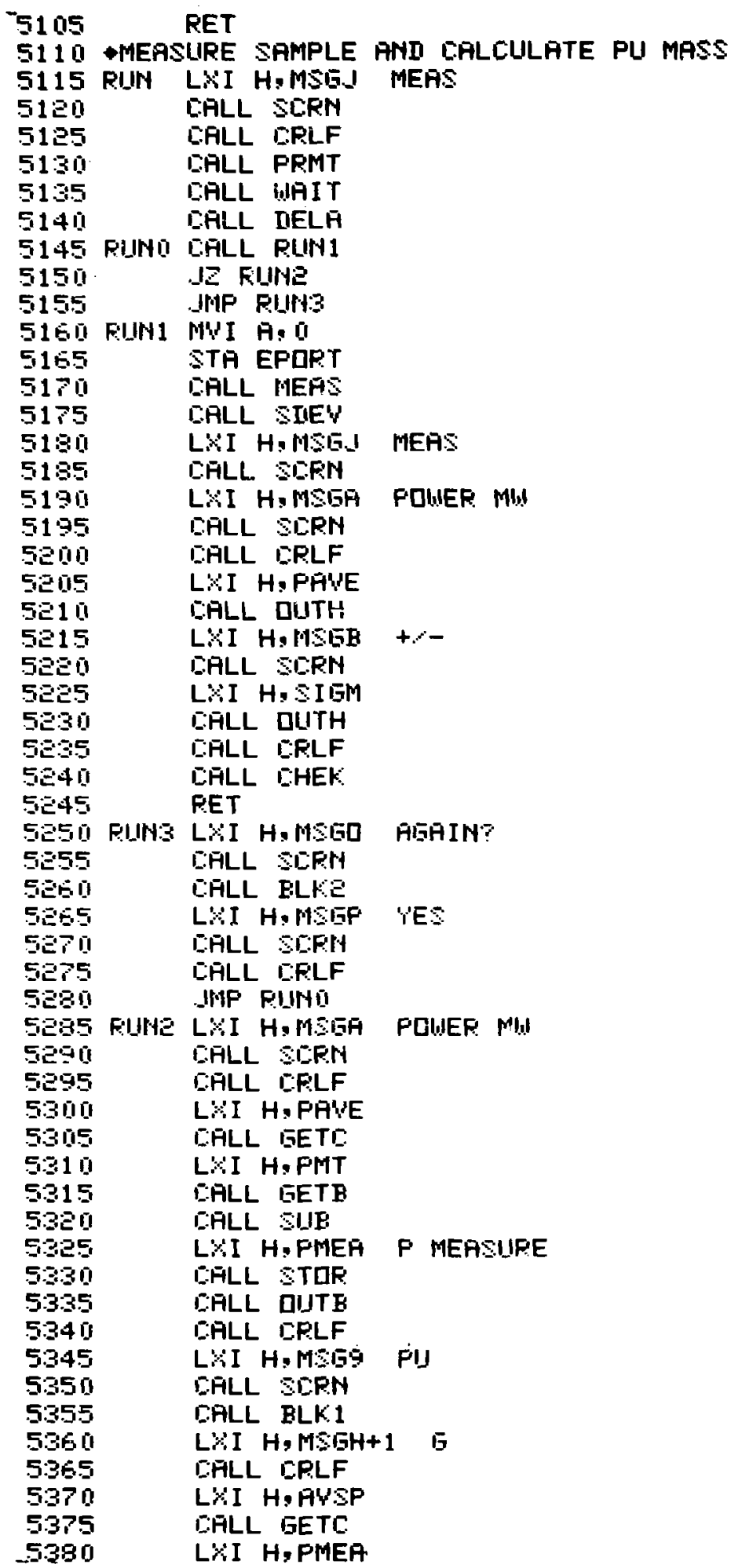




\begin{tabular}{|c|c|c|c|}
\hline $091 E$ & CD & $9 F$ & 16 \\
\hline 09리 & EII & 75 & $\mathrm{OF}$ \\
\hline 문ㄹㄴㄴ & 己1 & B1 & 30 \\
\hline 0927 & $\mathrm{EI}$ & $\mathrm{AP}$ & 16 \\
\hline ด्ञอत & EI & $7 \mathrm{~B}$ & 16 \\
\hline 0y료 & 21 & $\overrightarrow{T A}$ & 17 \\
\hline 330 & $E n$ & 65 & 15 \\
\hline 33 & 21 & $\mathrm{~A}$ & \\
\hline 3 & En & $90^{\circ}$ & 16 \\
\hline & $\begin{array}{l}\text { CDI } \\
31\end{array}$ & 95 & 30 \\
\hline $3 F$ & EI & $\mathrm{AE}$ & 16 \\
\hline 942 & 21 & $9 B$ & 30 \\
\hline 945 & EII & 9 & 16 \\
\hline 943 & EII & 를 & DE \\
\hline 4 모 & $\Xi 1$ & 95 & 30 \\
\hline $4 E$ & EII & PF & 18 \\
\hline 01951 & E:D & 86 & DE \\
\hline 0954 & 21 & $\overline{\mathrm{HE}}$ & 30 \\
\hline 0 & EII & FF & 16 \\
\hline D95A & EII & 15 & 15 \\
\hline 0105 & EII & 70 & DF \\
\hline (1) & 21 & 95 & 30 \\
\hline 11963 & E.II & $\overrightarrow{H E}$ & 16 \\
\hline 1966 & 21 & 0 & 10 \\
\hline ii & EII & 90 & $1 E$ \\
\hline 0 & $\Xi 1$ & EШ & 30 \\
\hline DF & OII & FF & 16 \\
\hline 0972 & EII & 70 & IIF \\
\hline 0975 & EI & 2E & $\mathrm{DE}$ \\
\hline 0978 & $\Xi 1$ & 95 & 30 \\
\hline VIE & EII & SF & 16 \\
\hline 17\% & EII & 3 & UE \\
\hline $0 \% 1$ & 01 & $E 3$ & !n \\
\hline 0984 & ¿1 & B1 & 30 \\
\hline 11980 & EII & $G F$ & $1 E$ \\
\hline ПНОН & $E I$ & $E 1$ & DIF \\
\hline $0198 \mathrm{I}$ & EII & $7 \mathrm{~B}$ & 16 \\
\hline 0990 & EII & $6 F$ & 16 \\
\hline$I^{11}=$ & EI & & ב9ּ \\
\hline 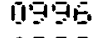 & $\therefore A$ & 91 & 18 \\
\hline 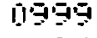 & 13 & $E 0$ & 16 \\
\hline 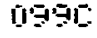 & $E 1$ & IIE & 17 \\
\hline Fביביבים & E:II & $E$ & 16 \\
\hline DOAE & EII & 75 & 15 \\
\hline 109A & $3 E$ & 02 & \\
\hline DIAP & IIS & 38 & \\
\hline 0919 & EII & 63 & 16 \\
\hline DGAL: & FE & $\square \bar{A}$ & \\
\hline $\begin{array}{l}0 \mathrm{HE} \\
1 \mathrm{HFF}\end{array}$ & $F$ & & \\
\hline $09 \mathrm{BO}$ & $n 3$ & 38 & \\
\hline $0 \mathrm{BE}$ & $F_{1}$ & & \\
\hline $09 \mathrm{~B} 3$ & F5 & & \\
\hline . & 21 & ES & 1 \\
\hline
\end{tabular}

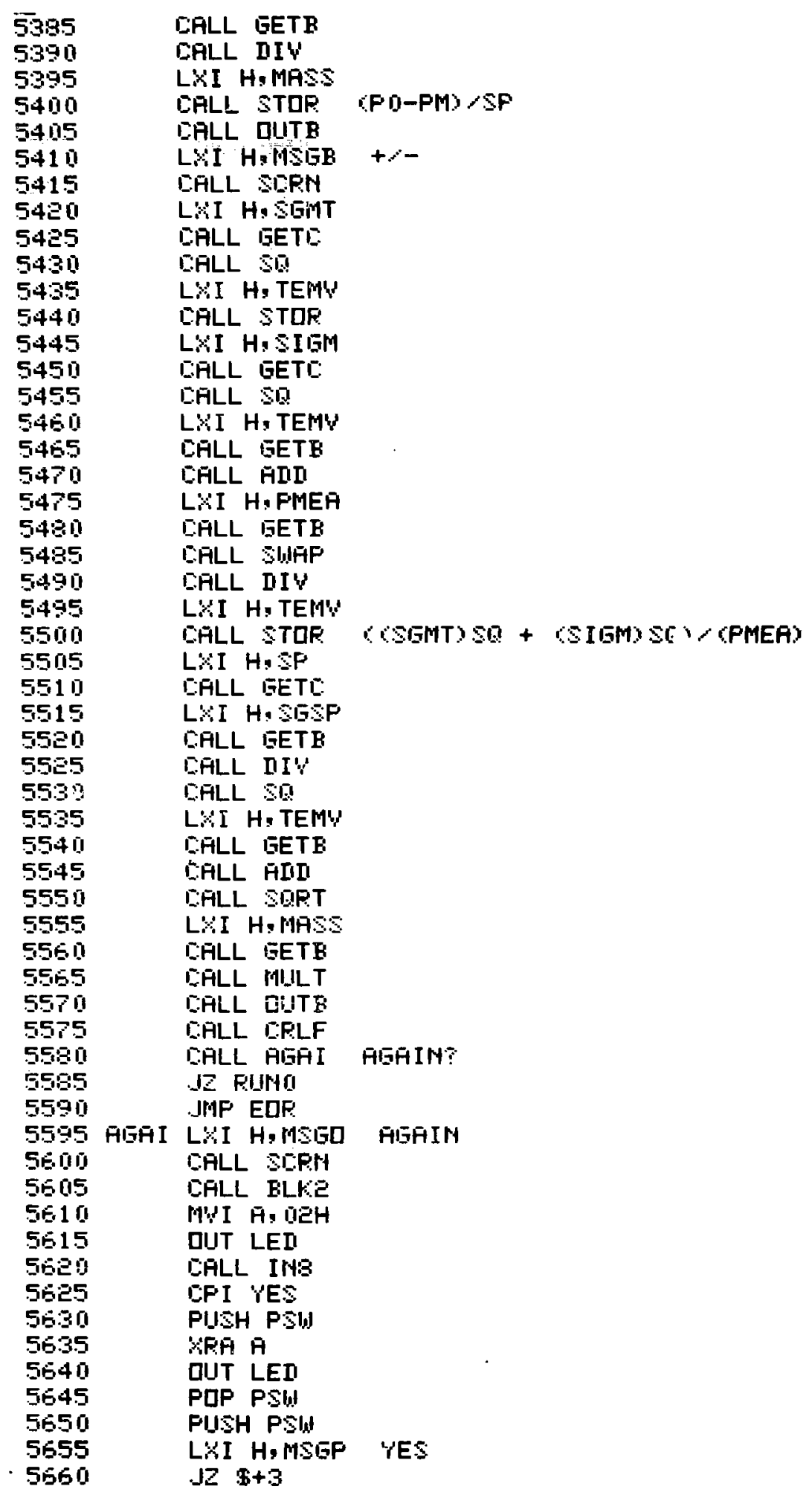

5395

5390

5395

5400

5405

5410

5415

5420

5425

5430

5435

5440

5445

5450

5455

546

5465

5470

5475

5430

5485

5490

5495

5.500

5.50 .5

5510

5515

5520

5525

$553 ?$

5535

5540

5545

5550

5555

5560

5565

5570

5575

5080

5595

5590

5595

5605

5610

5615

5620

5525

5030

5635

5640

5645

5650

5655

- 5560

CALL GETB

CALL DIW

LXI H.MASS

CALL STOP (FO-PM) SP

EALL DUITB

LYI HMMSGB +

EALL SIDPN

LYI H.SGMT

CALL GETE.

CFLL 30

LYI H: TEMW

CALL STOR:

LXI H:SIGM

EALL GETE

CALL SI

LYI H,TEMY

CFLL BETE

CHLL HIII

LXI H, FMEA

CALL BETE

EALL SIJPF

CFLL DIV

LXI H. TEMY

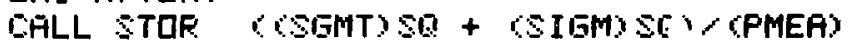

LXI H.SP

CALL BETE:

LWI H. SIG $\mathrm{P}$

CALL GETB

SFLL IIY

CFLL $S 0$

LYI H, TEMY

CFLL GETE

CFLL AIII

EALL SDPT

LXI H. WASS

GALL GETB

GALL MIILT

CALL DIITE

CALL EPLF

SALL AGFI ABEAINT

II RUNA

JMP EDP

AIGAT LYI H, MSGO FIBAIN

CALL BIPAH

CALL ELKE

MWI $A, O E H$

DUT LEI

CALL IYHB

CPI YES

PIISH PSW

XPA $A$

QUT LED

PUP PSW

FUSH PSW

LXI H, MSGP YES 


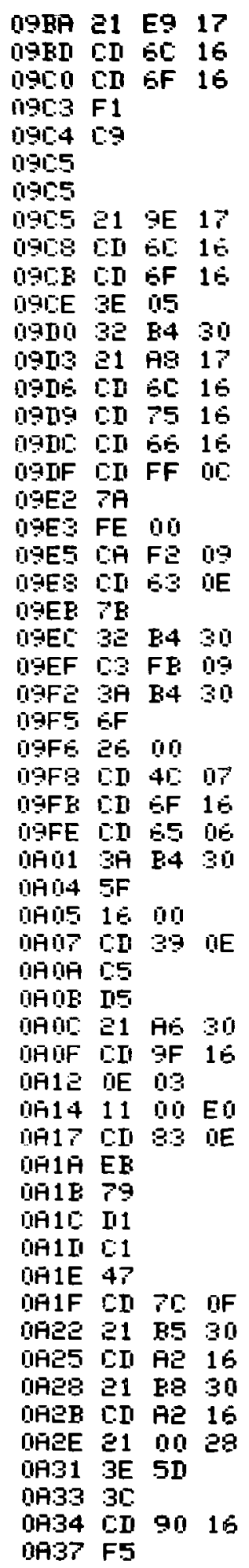

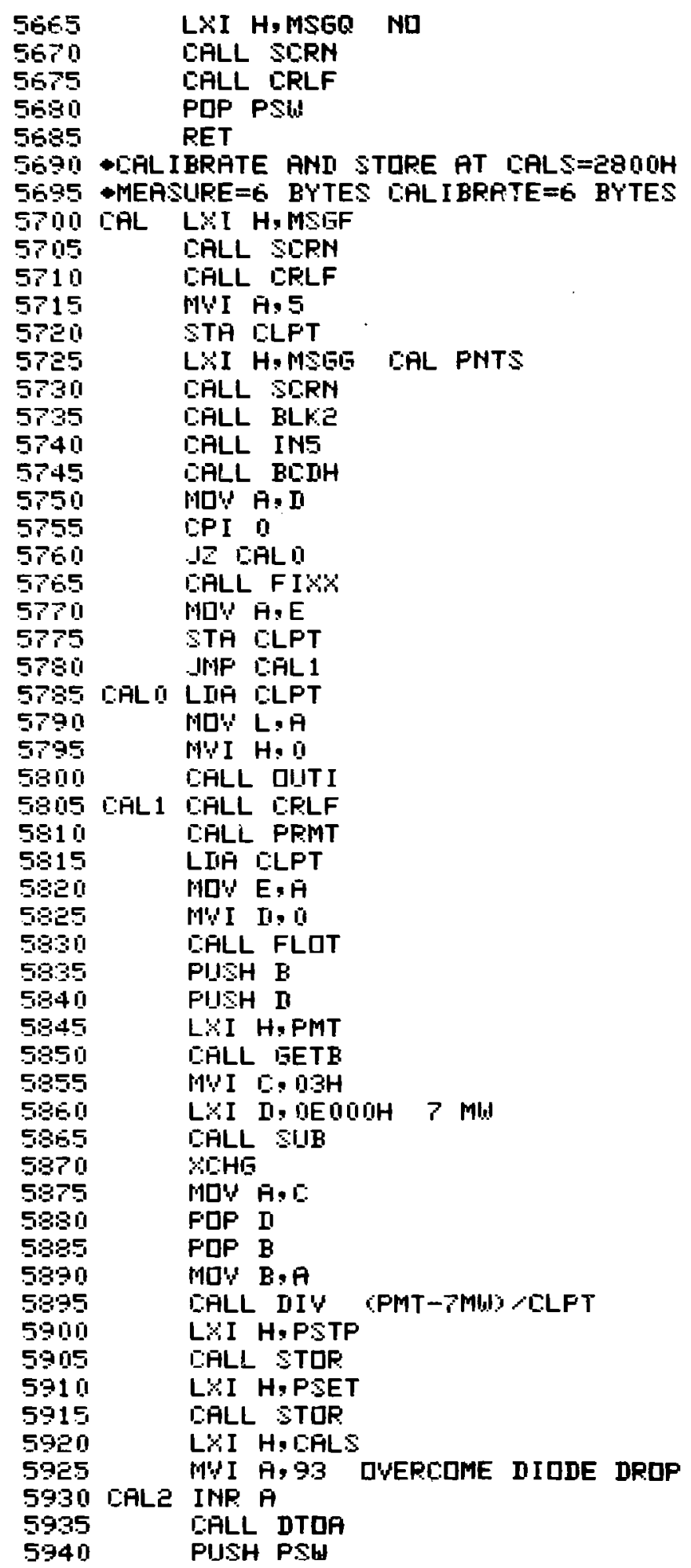


DA33 E5

DA39 $3 E$ OE

DABB ED 9316

OABE 21 B8 30

OH41 ED GF 16

OHA4 LD $93 \quad 0 E$

OAH47 79

OAH4B EG 80

OH4A $\mathrm{CE}$ SE Ü

OR4 $\mathrm{EI}$

GAFAE $F_{1}$

OR4F O3 23 OA

uRse CD EC 0.

0H55 $3 E$ OE

UITSP 32 EB 30

DHFA $3 E$ OA

IASE: IIS $3 \mathrm{E}$

UTSE DII OI: DG

UABS1 $\mathrm{AF}$

IIASE IIS $3 E$

OAAS4 CI BE 05

UAB 21 SE 17

OAREA CD SE 15

QHEI 21 TS 17

JATO CI 60 16

DA $\overrightarrow{3} 3$ CI $6 \mathrm{~F} 15$

口IATS 21 98 30

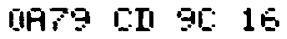

GAFC E1

DATII DI AE 16

UIAB ES

IIAB CI $T E$ IS

DAF 21 PA 17

DAB CD E 16

MABa el $9 \mathrm{E}$ 30

UAEI DII 90 16

UIF $\mathrm{E} 1$

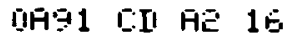

DHO4 E.5

ORGS $\mathrm{CD}$ PE $1 \mathrm{E}$

OHAS ID EF 18

GH' $\mathrm{OE}$ OH

IIAOII IIS $3 \mathrm{E}$

UAFF CD OH

IIAAE AF

IIAAS IIS $3 \mathrm{~B}$

ИHFS $21 \quad 98 \quad 30$

DAFE CII OC 16

IIAFE E1

DAFI: CD AE 16

DIAAF E5

OABO 21 जB 30

OABS CD 9C 16

DAEE E1

DAB CD A2 16

OÄBA CA D9 OA

\begin{tabular}{|c|c|c|}
\hline 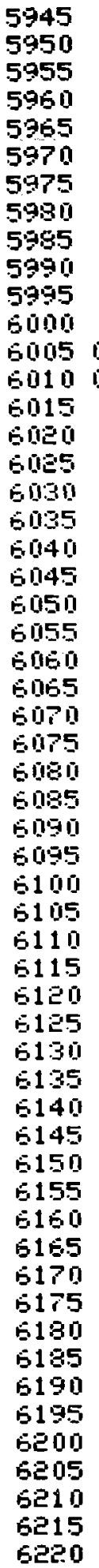 & $\begin{array}{l}\text { CALS } \\
\text { BFLS }\end{array}$ & 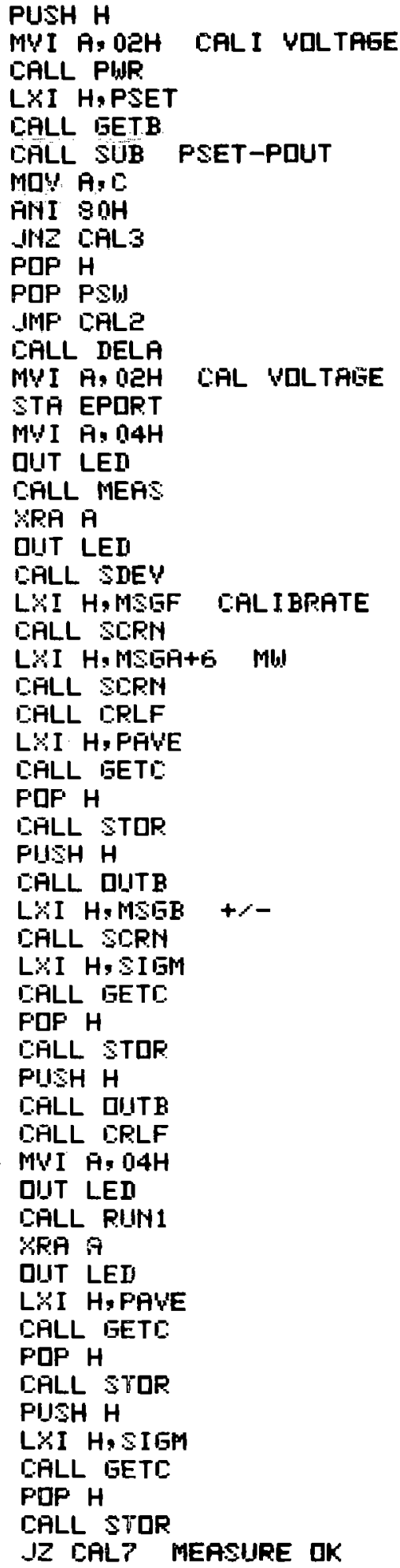 \\
\hline
\end{tabular}




\begin{tabular}{|c|c|c|c|c|c|c|c|c|}
\hline \\
\hline OARD & 28 & & & 6225 & & $\operatorname{DCx}$ & & \\
\hline OFAE & $2 B$ & & & 6230 & & ILX & $\mathrm{H}$ & \\
\hline UARF & $\mathrm{ZB}$ & & & 5235 & & $\operatorname{Iix} 1$ & & \\
\hline OAEOO & ZB & & & 5240 & & DEx 1 & $H$ & \\
\hline DAL: 1 & eR & & & 5245 & & Dax & $H$ & \\
\hline 0405 & $\begin{array}{l}\text { ZH } \\
\text { E. }\end{array}$ & & & $\begin{array}{l}6250 \\
6255\end{array}$ & & $\begin{array}{l}\text { DEX I } \\
\text { PUSH }\end{array}$ & $H_{H}^{H}$ & \\
\hline OFI.4 & 21 & $\mathrm{nE}$ & 17 & 6260 & & LXI & $H: M \$ B 0$ & FEFIN? \\
\hline OAET & EN & $B$ & 16 & 6255 & & EALL & L SEPN & \\
\hline QHEA & EII & 75 & $1 E$ & E2ㄱㅁㅁ & & CÁLL & L ELKE & \\
\hline OAEI & 21 & E5 & $1 \vec{i}$ & 6275 & & LXI & H.MSEP & $Y \mathrm{ES}$ \\
\hline ÖHII! & E.I & 60 & 16 & 5800 & & CALL & L Sorit & \\
\hline OHIIS & EII & $B F$ & 16 & $6=85$ & & EALL & L ERLF & \\
\hline OAIIS & 53 & $9 \mathrm{E}$ & $D A$ & 6290 & & JMP & E.AL 4 & \\
\hline OHIIS & E5 & & & $\therefore=5$ & EAL 7 & PJSH & $+H$ & \\
\hline UIAIA & $3 \mathrm{H}$ & B4 & 30 & 5000 & & LIA & E.LPT & \\
\hline GANI & $3 \pi$ & & & 5305 & & nCF & A & \\
\hline OADE & 30 & 54 & 30 & 5310 & & STA & ELPT & \\
\hline MRE 1 & $\mathrm{CA}$ & FE & ât & 5315 & & 20 & EALG & \\
\hline GHE4 & 21 & E13 & 30 & 5320 & & LYI & H:PSET & \\
\hline OHE $\bar{i}$ & En & 90 & 15 & 6325 & & CALL & - GETC & \\
\hline VREA & $\begin{array}{l}E 1 \\
5 \pi\end{array}$ & 85 & $\begin{array}{l}30 \\
16\end{array}$ & 5030 & & LXI & $\begin{array}{c}\text { H.PSTP } \\
\text { GETR }\end{array}$ & \\
\hline $\begin{array}{l}\text { OAEED } \\
\text { OAFO }\end{array}$ & $\begin{array}{l}\text { EII } \\
\text { CI }\end{array}$ & 85 & $\mathrm{DE}$ & $\begin{array}{l}5335 \\
6340\end{array}$ & & $\begin{array}{l}\text { EALL } \\
\text { EALL }\end{array}$ & & \\
\hline UARF 3 & 21 & EAE & 30 & 6345 & & LXI & H.PSET & \\
\hline OAFE & EII & $\mathrm{AP}$ & 15 & 6050 & & E.HLL & L STAF & \\
\hline DAFG & E1 & & & 635 & & PपF & $H$ & \\
\hline DAFA & F1 & & & 530 & & PAF & FSW & \\
\hline DIAFE & 63 & 33 & IIA & 5365 & & INTP & EALE & I0 NEXT \\
\hline QAFE & $\mathrm{AF}$ & & & 5370 & EALE & XRA & $\overline{\mathbf{H}}$ & \\
\hline IIFFF & $E I$ & 90 & 15 & $B$ & & EALL & L ITUA & \\
\hline OEOE & 3 & 50 & 15 & 5 & & $\mathrm{MPF}$ & EDP & \\
\hline 0 015 & & & & 5 & $\mapsto$ BET & TEST & T PDINTS & \\
\hline 0605 & 21 & 50 & 17 & 5390 & TEST & LXI & H,MSGK & TEST PT \\
\hline पE IIS & ED & 60 & 16 & 6395 & & EALL & L SLRH & \\
\hline TEOE & 0 & $5: 3$ & & 6400 & & $M Y I$ & B. 3 & \\
\hline OEEII & EI & 69 & 15 & 8405 & & EALL & L DUTB & \\
\hline $0 E 10$ & $3 E$ & $\mathbf{F F}$ & 30 & $\begin{array}{l}5410 \\
5415\end{array}$ & & MUI & $\bar{A}$, OFFH & \\
\hline $\begin{array}{l}\text { पE } 12 \\
0 E 15\end{array}$ & 30 & $\begin{array}{l}B E: \\
A 0\end{array}$ & $\begin{array}{l}30 \\
30\end{array}$ & $\begin{array}{l}5415 \\
5420\end{array}$ & & $\begin{array}{l}\text { STA } \\
\text { STA }\end{array}$ & $\begin{array}{l}\text { PDINT } \\
\text { FLAG } 1\end{array}$ & \\
\hline 0818 & ED & $E F$ & 16 & 5425 & TESO & EALL & L ERLF & \\
\hline $\mathrm{DE} 1 \mathrm{E}$ & $\Xi 1$ & 98 & 17 & 5430 & & $L \because I$ & H.MSGE & FLL? \\
\hline DE1E & EII & $E C$ & 16 & 5435 & & EALLL & $L$ SCRY & \\
\hline ดE:1 & EI & $\vec{r}$ & 16 & 5440 & & EALL & L BLKE & \\
\hline DE24 & $E I$ & 18 & $0 \vec{\gamma}$ & 5445 & $T E S P$ & EALL & L RSVP & \\
\hline OEET & FE & OA & & 5450 & & EPI & YES & \\
\hline पE29 & EA & 46 & $\mathrm{aE}$ & 5455 & & $\int \mathrm{T}$ & TES 1 & \\
\hline OEEC: & FE & 30 & & 5460 & & EFI & ENTR & \\
\hline IBEE & $C A$ & 46 & $0 \mathrm{~B}$ & 5465 & & $2 T$ & TES 1 & \\
\hline पB 31 & CI & FF & OII & 6470 & & CHLL & L BEDH & \\
\hline 0184 & $\mathrm{cn}$ & 63 & $\mathrm{OE}$ & 6475 & & CALL & $L F \operatorname{Ixx}$ & \\
\hline 0137 & 78 & & & $\begin{array}{l}6480 \\
6485\end{array}$ & & $\begin{array}{l}M W^{\prime} \\
\mathrm{CPT}\end{array}$ & $A, E$ & \\
\hline n8:38 & $\begin{array}{l}F E \\
D ?\end{array}$ & $\begin{array}{l}33 \\
18\end{array}$ & $O B$ & 6490 & & EPI & $\begin{array}{l}3.3 H \\
\text { TESO }\end{array}$ & \\
\hline $\begin{array}{l}\text { MB } 3 A \\
0 B 30\end{array}$ & 32 & $\mathrm{BC}$ & 30 & 6495 & & $\begin{array}{l}\text { STH } \\
\text { STA }\end{array}$ & PDINT & \\
\hline $9 \mathrm{~B} 40$ & $\mathrm{CD}$ & $6 E$ & 16 & 6500 & & CALL & L CRLF & \\
\hline
\end{tabular}




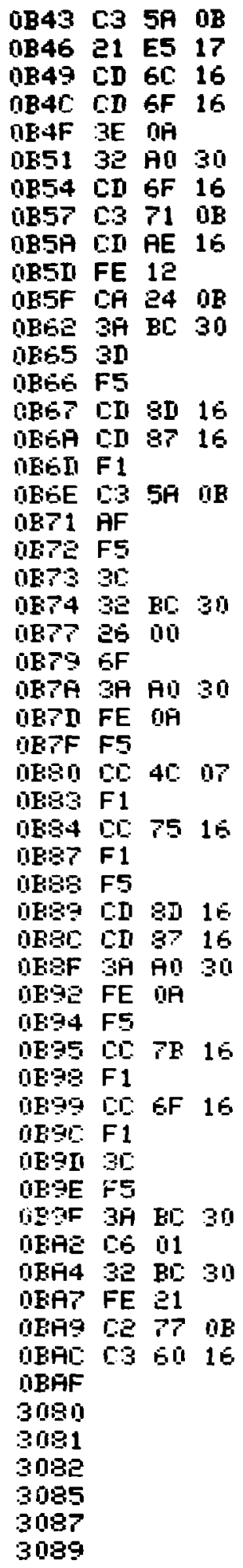

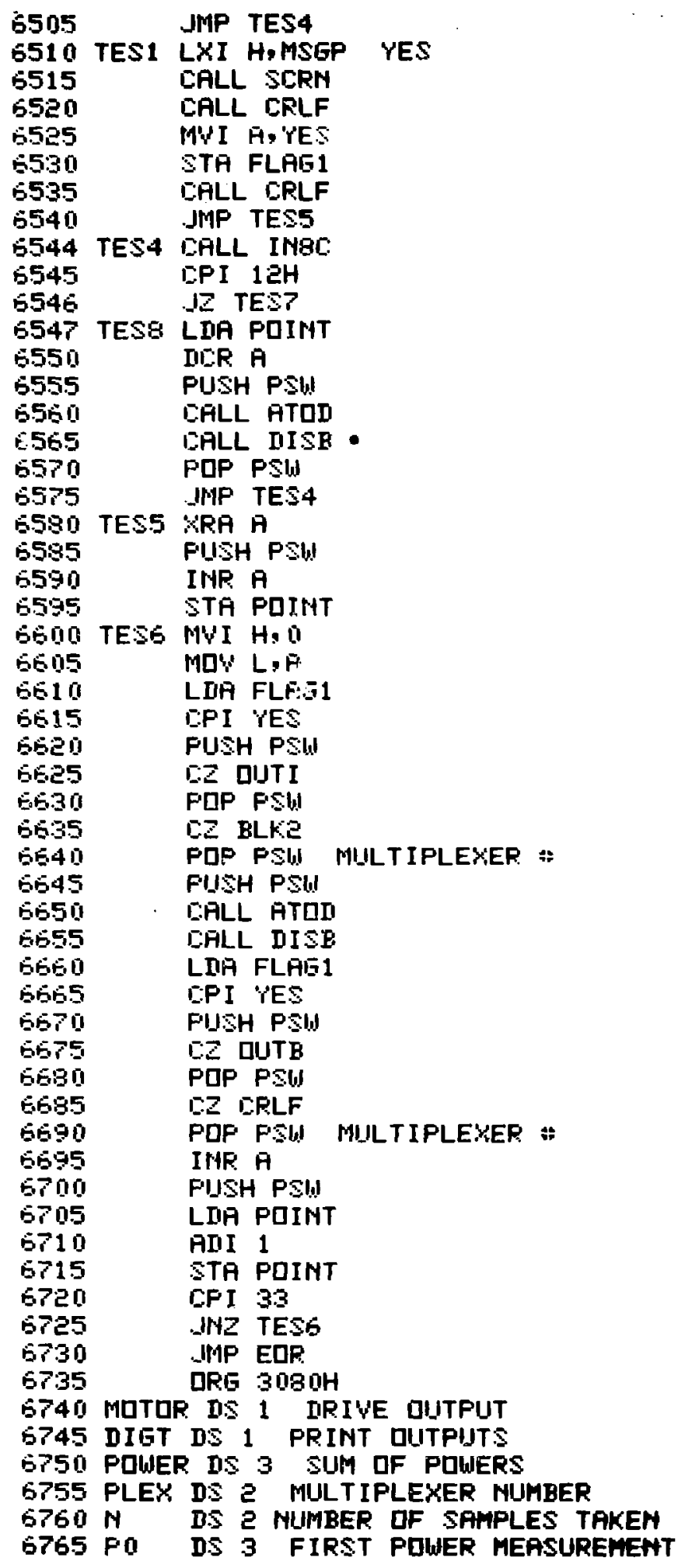


$308 \mathrm{C}$

$30 \mathrm{BF}$

309

3095

8108

$30 \mathrm{E}$

SIIJE

SÜA

Bด1

30104

उIAT

3010

BUAL:

3IIAE

SUIE 1

304

$30 \mathrm{ES}$

SUE:

$30 \mathrm{FE}$

GOEL

उUEI

ant: 1

जili:4

30

3 ili:

3010

30

00

3 ail

alio

3010

3010

3010

3010

300

son

307

30

300

solo

3107

ani 7

301:?

3 ํㅣㅇ

300.7

307

$30 \mathrm{c}$

30.7

3007

3007

3 ing

3007

$30 \mathrm{a}$

30 ?

$30 \mathrm{cr}$

3007

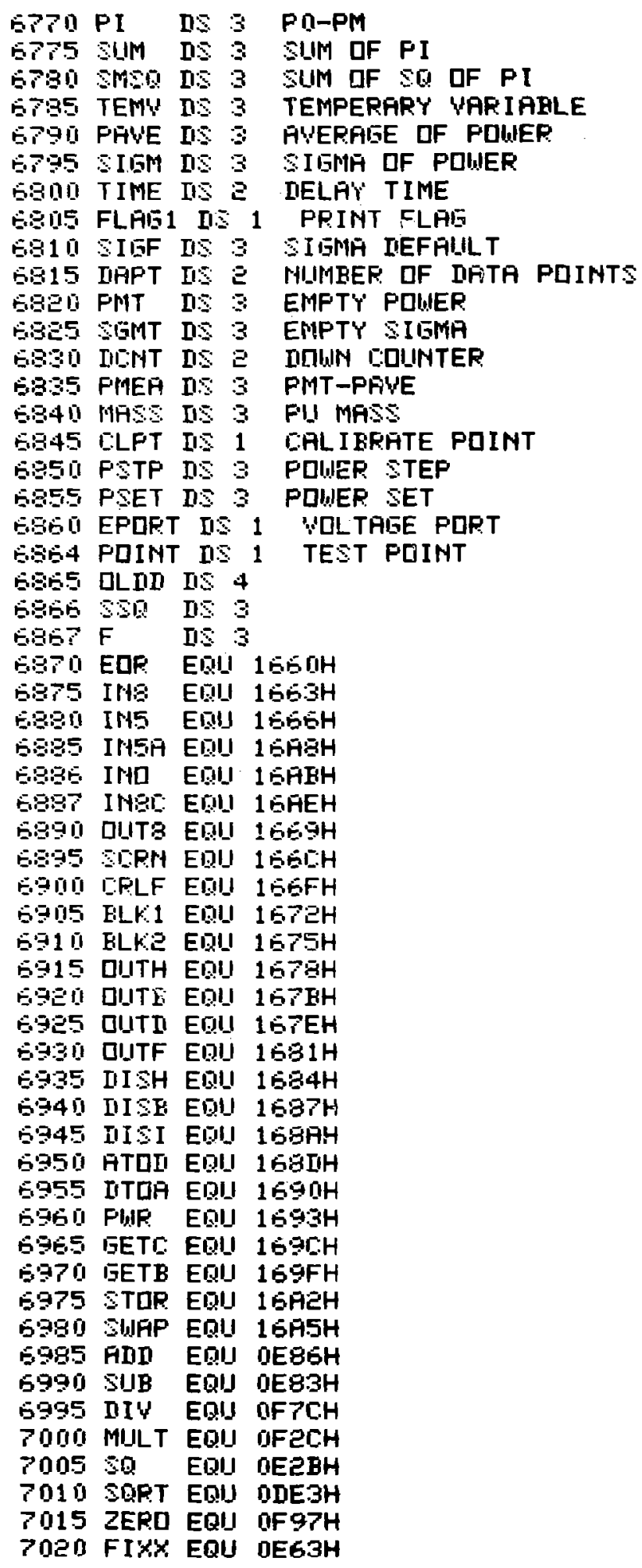




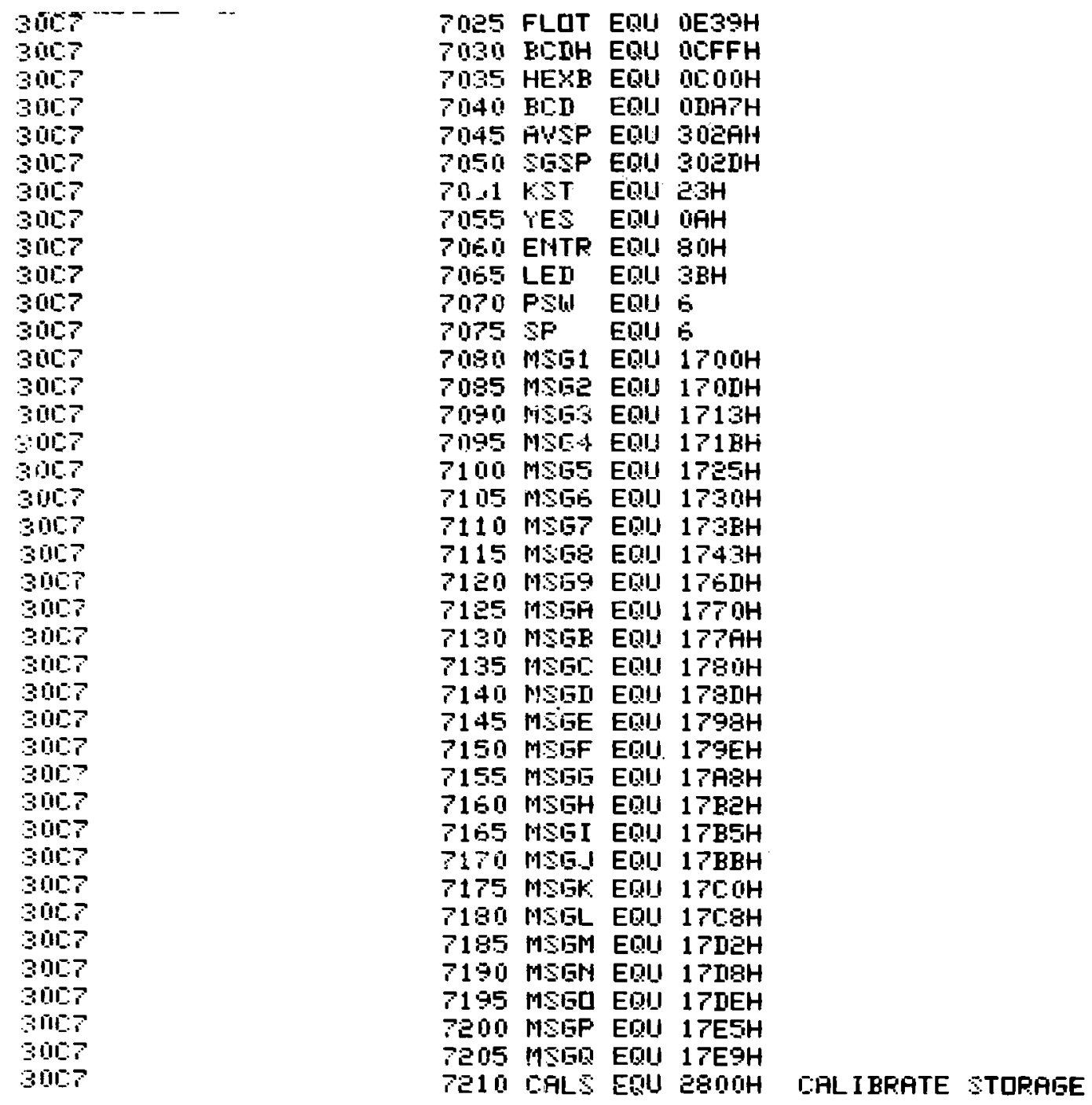


10010

1000

1 GIIO $3 \mathrm{E} \quad$ O4

1 nuge IIS $3 \mathrm{~B}$

10104 CII ESE 11

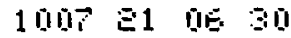

1 DOMA EE 1E 30

1001 E1 $5 \vec{i} 11$

1 1110 ออ 15: 30

1 U13 $3 \mathrm{E}$ 1.5

$1015321 \mathrm{~F}$

1010 CI 15

1 IIE $21 \quad 15 \quad 30$

1U1E CII FF 16

1021 GI

1024 LI BE 11

10 II EA IE 30

$10 \mathrm{DH}$ EI GF $1 \mathrm{E}$

1 IEII EI EL OF

100 ZA $1 \mathrm{E} \quad 30$

1033 EII $A E$ 1E.

1030 EA 1E 30

1009 EII 5011

100 ZE $1 E$ 30

$10 \mathrm{SF}$ EA 1E 30

104 EI 5011

1045 리 $10 \quad 30$

1048 SA $1 \mathrm{E} 30$

$104 \mathrm{E} 3 \mathrm{II}$

1045 OE 1510

$1 \Pi 4 F=1 \quad E 011$

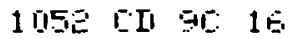

105521 प0 30

105 II GF 15

$1 D 5 E$ CI $E \mathrm{CO}$

$105 E \circlearrowright 1 \quad 1 \mathrm{E} \quad 30$

1 HE $\mathrm{CD}$ HE 15

$1004 \quad 2154 \quad 11$

10 CII ED 16

10 . 21 B 11

1 UEI EI OF 16

1 OTO CL $B:$ DE

1073 ㄴ $1 \mathrm{E} 30$

$1076 \mathrm{EL} \quad \mathrm{F}$ 16.

1079 III $7 \mathrm{C}$ OF

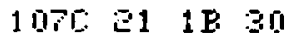

1 ITF EII AE 16

$10 \mathrm{ge} \quad 21$ 60 11

1035 다 9016

$\begin{array}{lllll}103 & 21 & 15 & 30\end{array}$

1 IISE ED GF 16

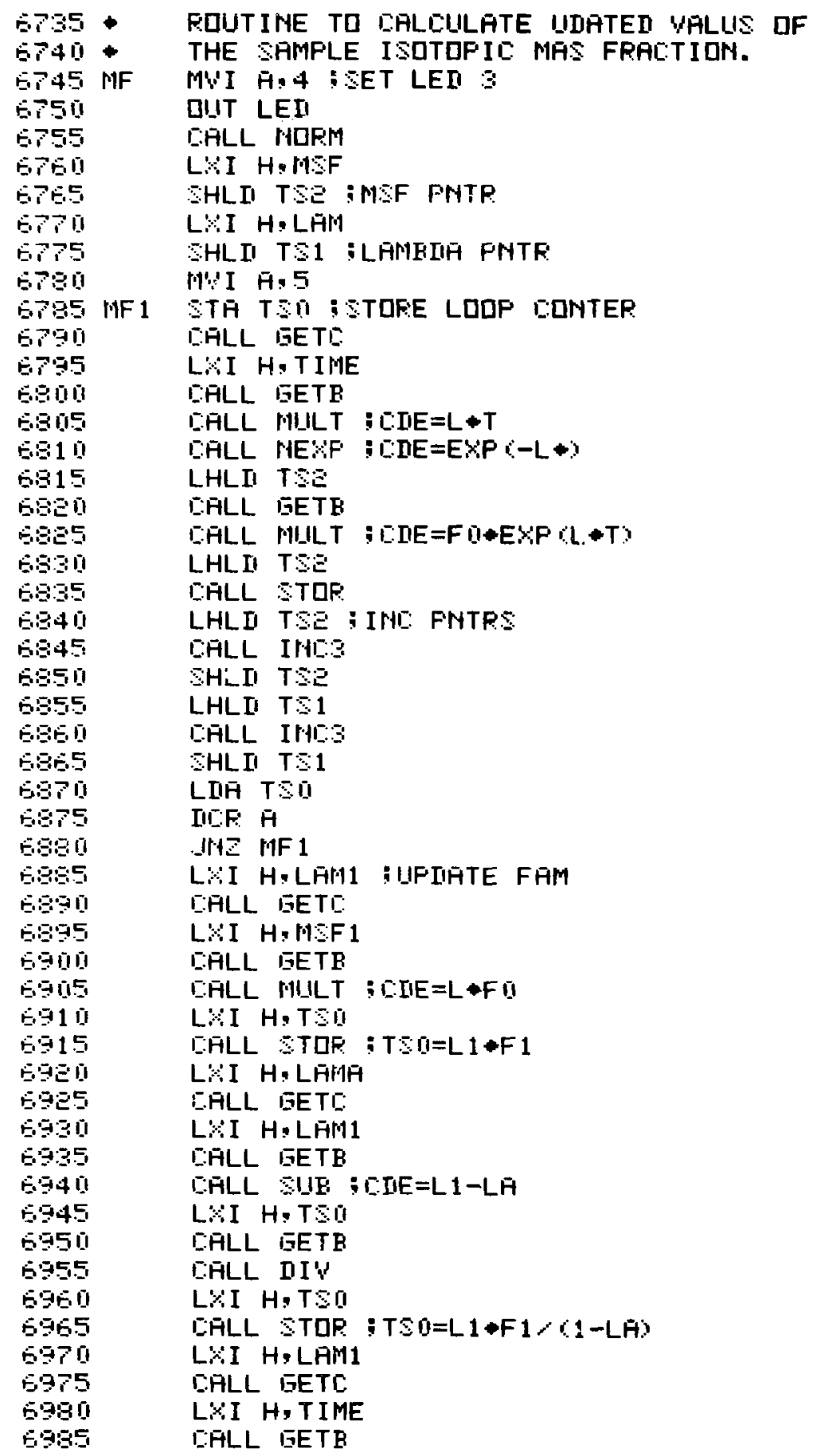




\begin{tabular}{|c|c|c|c|}
\hline $10 B E$ & En & $\mathrm{Ec}$ & $\mathrm{BF}$ \\
\hline 1091 & EI & 66 & 11 \\
\hline 1094 & $巳 1$ & $1 \mathrm{E}$ & 30 \\
\hline 1097 & E. & $9 F$ & 16 \\
\hline $10 \% A$ & EI & $\overrightarrow{\mathrm{E} C}$ & DF \\
\hline $109 n$ & 21 & $1 E$ & 30 \\
\hline 1 ORП & EI & $A E$ & 15 \\
\hline 1 UHO & $\Xi 1$ & 54 & 11 \\
\hline 1 OHE & $\therefore I$ & 90 & 16 \\
\hline $1 \square \bar{Q}$ & e1 & 15 & 3 \\
\hline 1 UAL & EI & $9 F$ & 16 \\
\hline 1 UIAF & EI & 20 & oF \\
\hline $10 \mathrm{EE}$ & $\mathrm{En}$ & 66 & 11 \\
\hline 10 & $\mathrm{ei}$ & 21 & 30 \\
\hline 10 IOE & EII & $\mathrm{AE}$ & 10 \\
\hline $10 \mathrm{EE}$ & 넌 & 18 & 80 \\
\hline 1 UEE & & & 15 \\
\hline 101 & EI & $\mathrm{EL}:$ & üF \\
\hline 1004 & $\Xi 1$ & $1 E$ & 30 \\
\hline 10107 & EN & $9 F$ & 15 \\
\hline 1 10. & EII & A5 & 15 \\
\hline $10 \leq 1$ & EI & 83 & DE \\
\hline 10 1010 & こ1 & $1 \mathrm{E}$ & 30 \\
\hline 1043 & $\because \mathrm{II}$ & $\overline{A B}$ & 16 \\
\hline $10 \pi$ & & & \\
\hline $10 \pi$ & $\Xi 1$ & i1: & 30 \\
\hline 1 ב & EII & & $1 E$ \\
\hline 1 IIIIE: & $\Xi 1$ & $\Xi 1$ & 30 \\
\hline 1 MIF & E:II & $9 F$ & 16 \\
\hline $1 \mathrm{AEZ}$ & EII & 30 & DIF \\
\hline 1 YES & 21 & $1 \mathrm{E}$ & 30 \\
\hline 1 DES & EII & $9 F$ & $1 E$ \\
\hline 1 UEE & EII & & DE \\
\hline 1 IIEE & 21 & 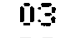 & 30 \\
\hline 1 IIF 1 & EII & $\overline{H E}$ & 18 \\
\hline 1 IIF 4 & En & EBS & 11 \\
\hline $1 \mathrm{OF}$ & E1 & $3 \mathrm{E}$ & 17 \\
\hline $1 \bar{Q} \bar{F}$ & EI & $\theta 0$ & 16 \\
\hline $1 \mathrm{~J} F \mathrm{II}$ & DII & $B F$ & 15 \\
\hline 110 & En & $E F$ & 15 \\
\hline 110 & 21 & 03 & 30 \\
\hline 110 & 2 & $1 \mathrm{E}$ & 3 \\
\hline 1109 & 21 & 43 & 1 \\
\hline 110 & $2 z$ & 15 & - \\
\hline 110 & $\mathrm{EE}$ & DE. & \\
\hline 1111 & ze & $1 \mathrm{E}$ & \\
\hline 114 & DI & - & \\
\hline 111 & $\vec{z}$ & $1 E$ & $=$ \\
\hline 1111 & 0 & - & 15 \\
\hline 11 ¿0 & 21 & $\neg$ & \\
\hline
\end{tabular}

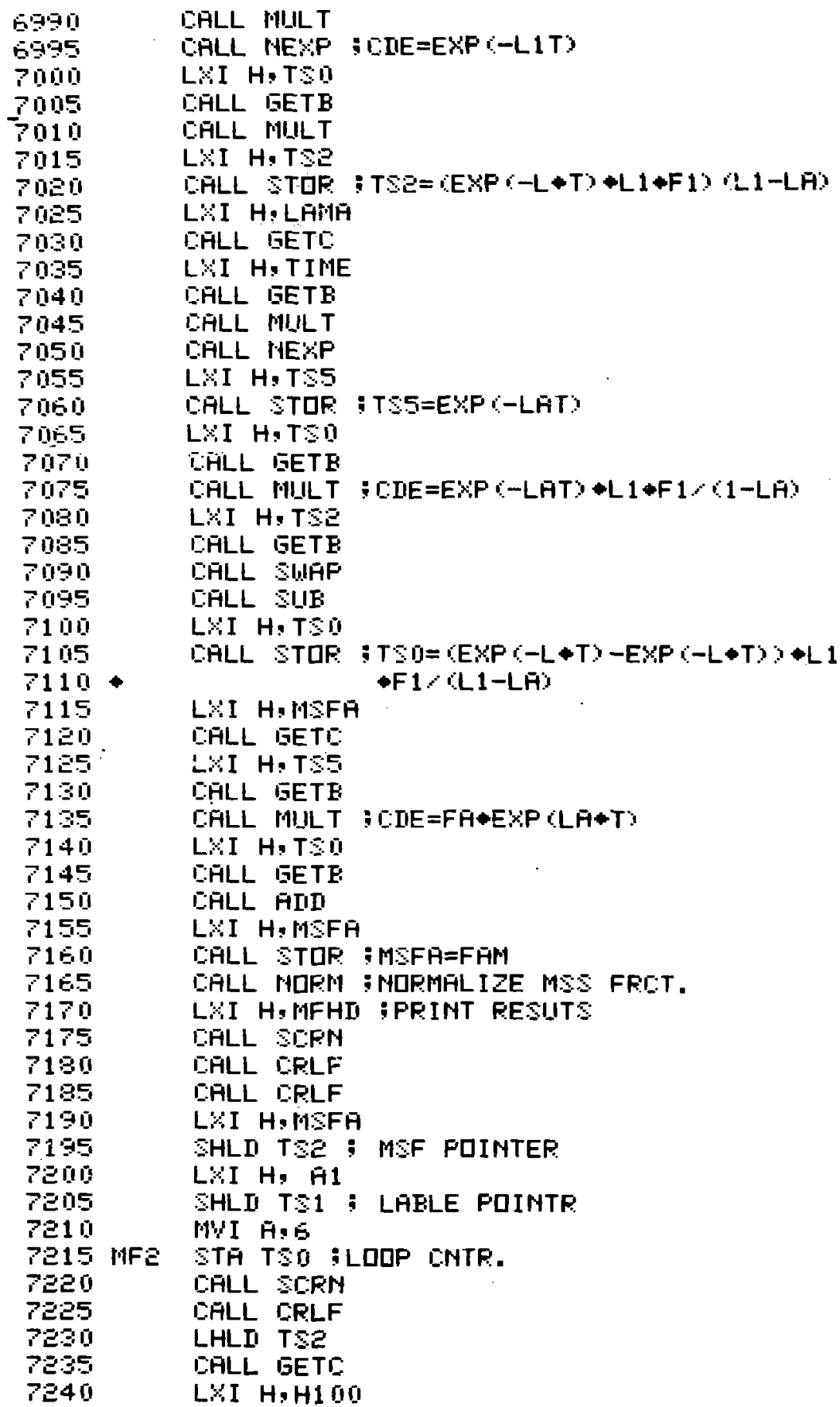


1150 21 27 30

1183 on of 16

1156 EI 20 OF

1159 है 25 Зी

$11 \mathrm{BC}$ 다 5011

$11 \mathrm{gF}$ 2E 2530

$119 \mathrm{E} \quad 24 \quad 30$

$1195 \mathrm{SI}$

1196 두 71

11992011

$1195 \mathrm{EI}$ GF $1 \mathrm{E}$

$119 \mathrm{~F}$ CI $\mathrm{BS}$ DE

$11 \mathrm{HE} \mathrm{CO}$

$119 \mathrm{~B} \overrightarrow{\mathrm{i}}$

$11 \mathrm{H} 4 \mathrm{EE}$

11 145 ก0

$11 \mathrm{HE} \mathrm{FA}$

$11 \mathrm{AP} B \mathrm{~B}$

$11 \mathrm{AB} \mathrm{BS}$

$11 \mathrm{AP} 7 \mathrm{O}$

$11 \overline{A F} \overline{A H}$

$11 \mathrm{AE} \mathrm{AE}$

$11 \overline{H I}$ : FE

$11 \mathrm{AII} \mathrm{AB}$

$11 \mathrm{HE} \mathrm{AB}$

$11 \mathrm{AF}$ OII

$11 \mathrm{EI} 50$

$11 \mathrm{~F} 1$ ini

$11 \mathrm{FE} 81$

$11 \mathrm{ES} 80$

$11 \mathrm{F4}$ 00

$11 \mathrm{E} 5 \mathrm{01}$

$11 \mathrm{EE}$ :

$11 \mathrm{EF}$ 00

$11 \mathrm{ES}$

$11 \mathrm{~EB}$

11 HE LII 97 IIF

$11 \mathrm{EE} 21 \quad 1830$

$11 \mathrm{FE}$ CII AE 15

$11[1$ ¿1 06 30

$11 \mathrm{~L}$ ह2 15 30

$11 \mathrm{CO} \quad 0 \mathrm{E}$

11593 1F 30

11 LE CD OF 16

$11 \mathrm{DF}$ EII BE OE

$11 \mathrm{II}$ एम 10 :0

11 IIS CII 5011

$11 \mathrm{IE}$ 25 10 30

$11 \mathrm{IE}$ उH $1 \mathrm{E}$ छU

$11 \mathrm{IE}$ GII 


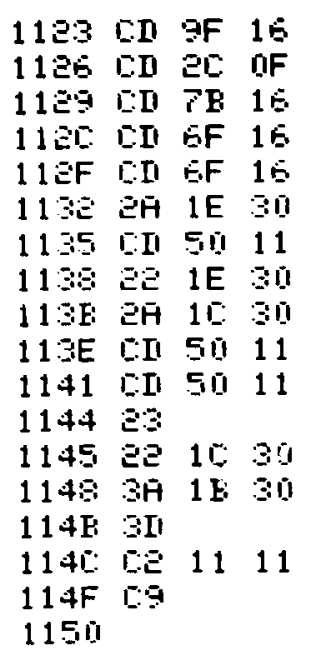

$1150 \quad 3$

115123

11503

115319

$1154 \mathrm{EF}$

11559

1156.5

$1157>1$

$115 \mathrm{ES}$

$115 \%$ 010

$115 \mathrm{H}$.

115E $\mathrm{AG}$

1 i $5 \mathrm{~T}$ : 3

i 15 II E.E:

$115 \mathrm{E} 9 \mathrm{E}$.

115F IIE

116074

$11518 \mathrm{~A}$

$11 \mathrm{GE}$

11635.5

$1164 \mathrm{AB}$

$11659 \mathrm{~B}$

$11 \mathrm{~s}$

$11 E$

116 巳1 2730

$11 \mathrm{E}$ III AE 16

11 E EII 97 IJF

$11 \mathrm{~F}$ e1 $\mathrm{A}: 11$

1172 2อ 2530

1175 3E UE.

117732 ㄴ 30

$117 \mathrm{~A}$ CII GF 16

$117 \mathrm{D}$ ED $\mathrm{BS}$ OE

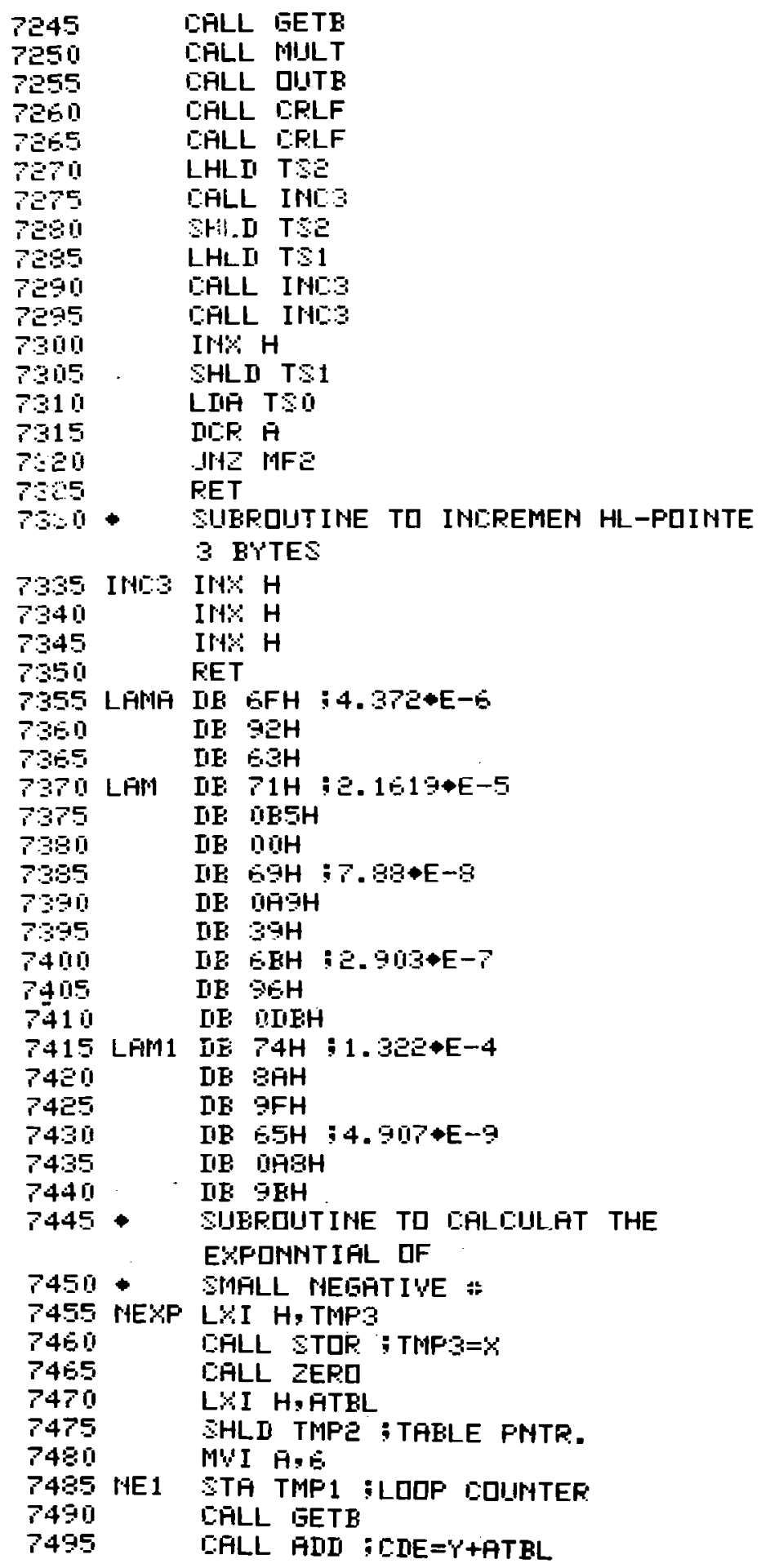




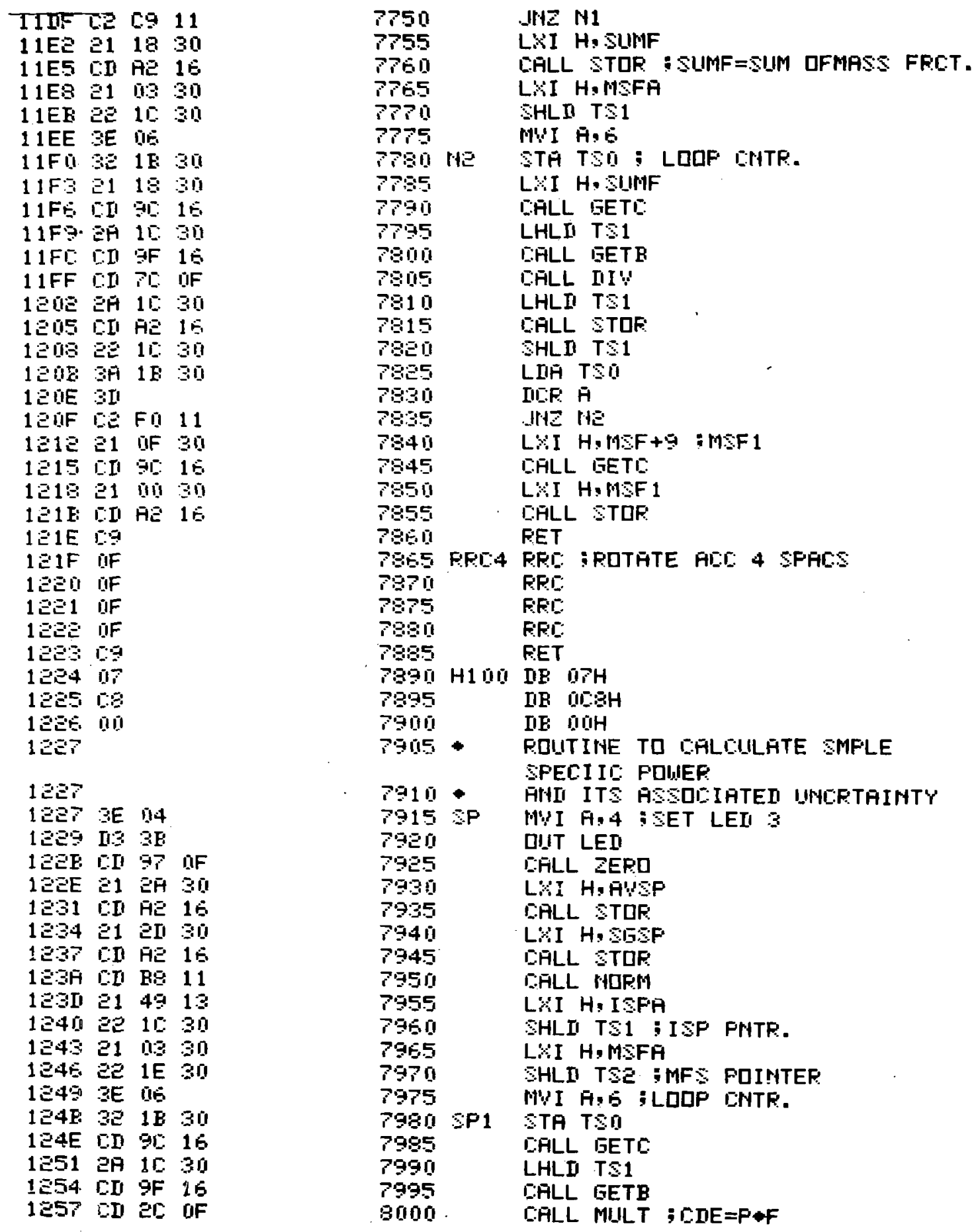




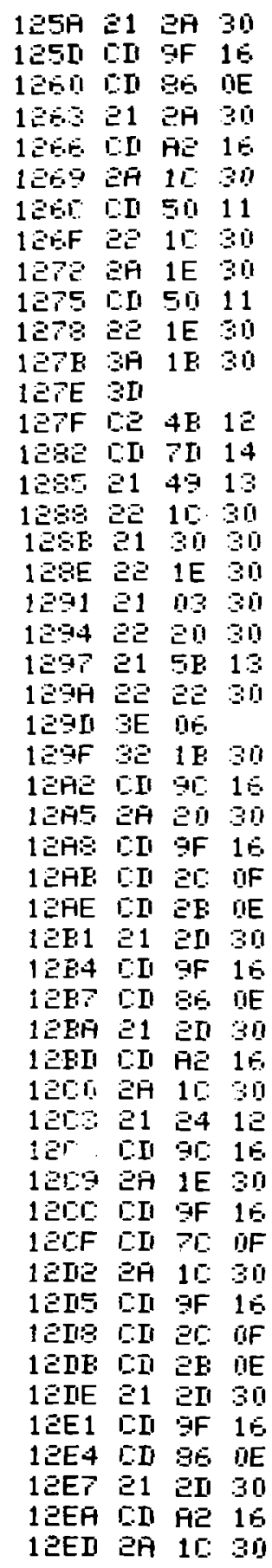

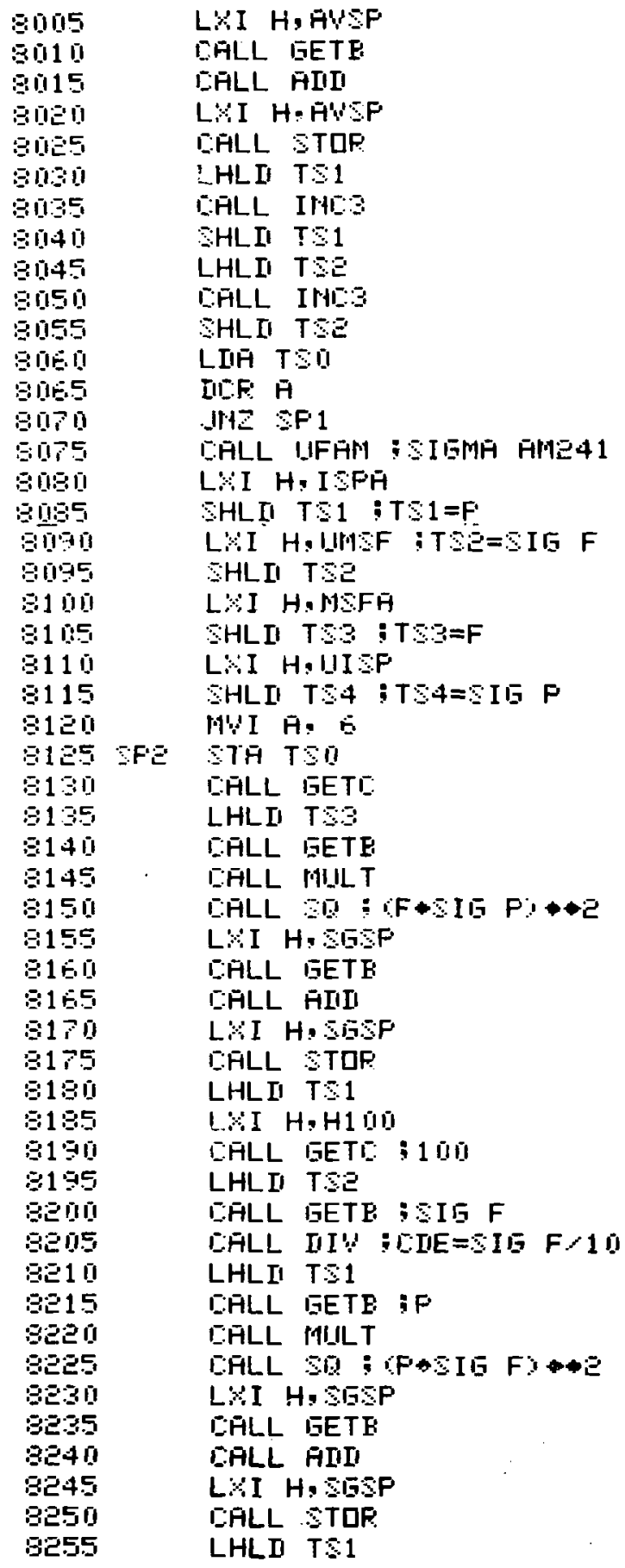




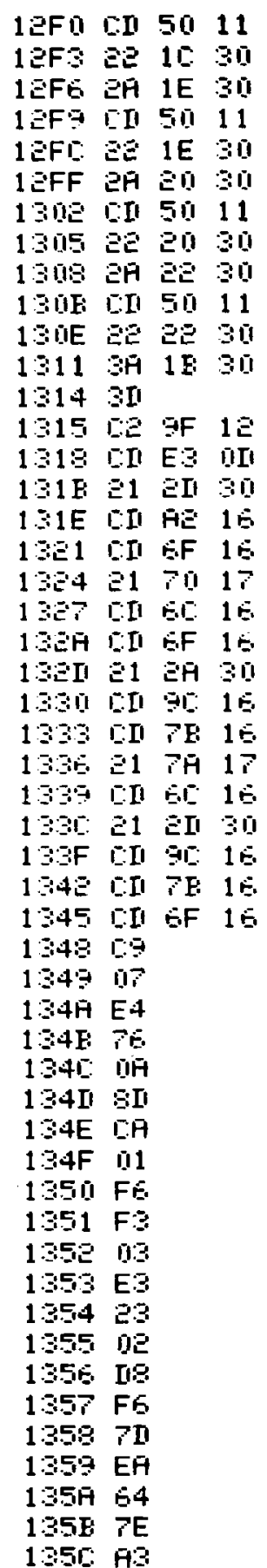

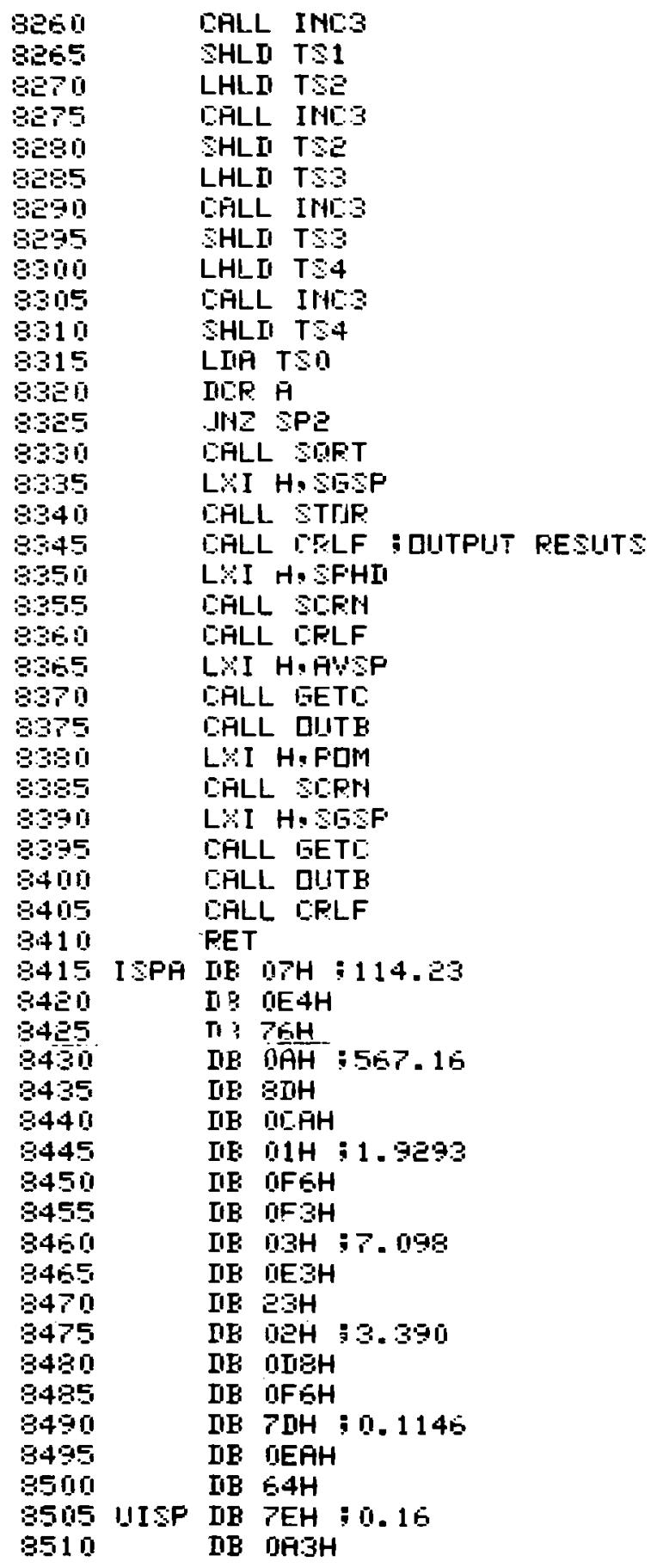




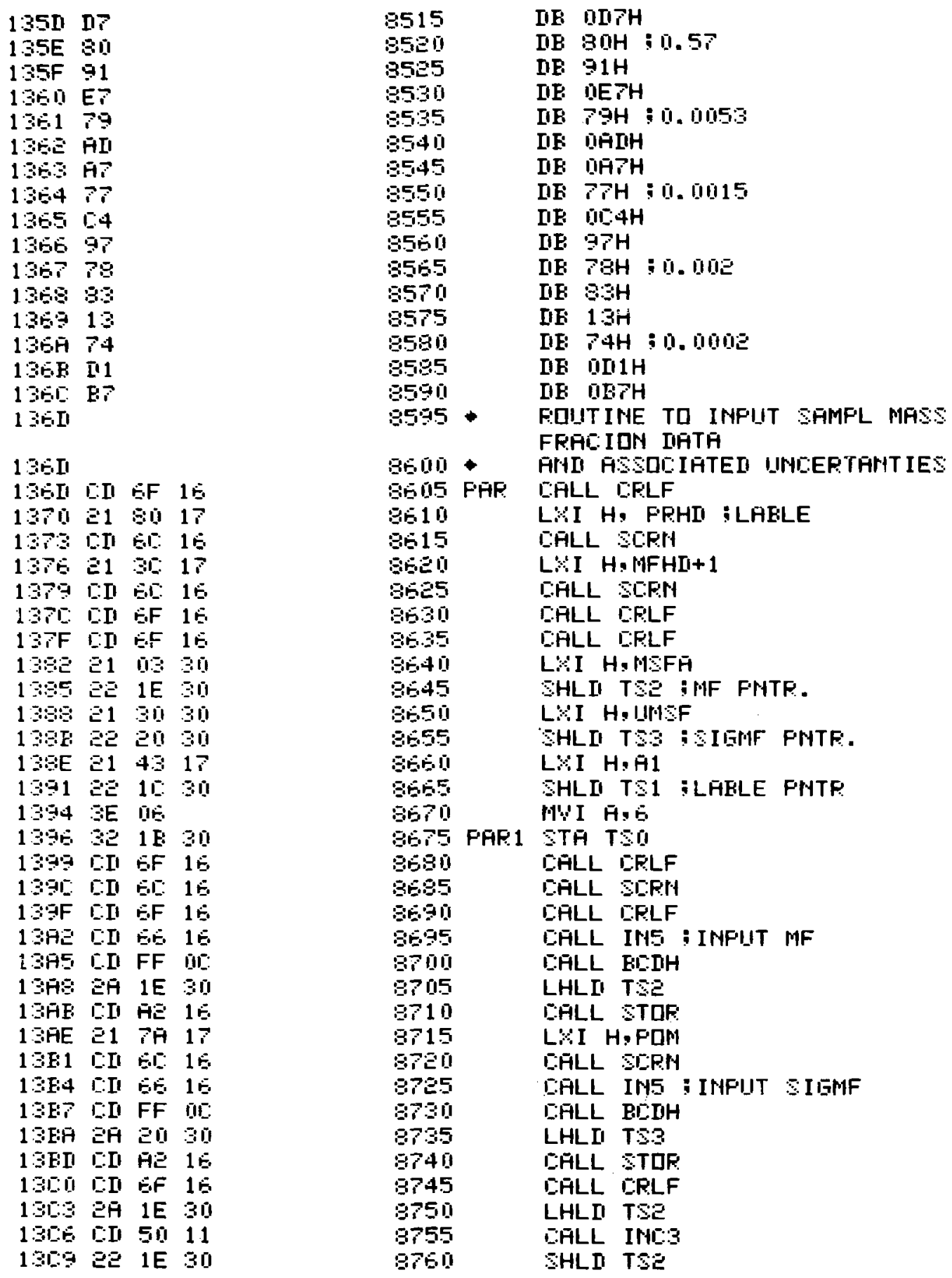


130 อA 20 उO

1 ICF EI 5011

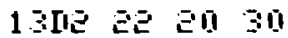

1 IIS $\mathrm{BA}$ 10 30

13IS EII 5011

13 IIE EI SII 11

13 IIE 23

$13 I 1 F \quad 2=10 \quad 30$

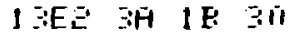

1 SES SII

1 BEE CE GE 13

$13 \mathrm{E} \quad \mathrm{E} \mathrm{SII} 17$

$13 E$ CII $6 F$ 16

$13 E F$ CI 6 C 18

$13 F E$ CI EF 10

$13 F 5$ EI ES 18

$13 F$ EII FF III

$1 \because F F \quad \Xi 1 \quad 15 \quad 30$

1 SFE EI AE 16

1401 II EF 13

14114 E1 IF 30

$14 \pi$ त्ञ

14 IIA 21 OU 30

14 III EII AE $1 \mathrm{E}$

$1410 \Xi 1 \quad 7017$

1413 r.II EF 18

1416 CII EO 15

$141 \% \Xi 1$ EE 17

1410 CII ER 16

$141 \mathrm{~F}$ EI EF $1 \mathrm{E}$

$14 E E$ CI BE $1 E$

1425 EI FF MI:

1429 こ1 $\mathrm{ZA} \quad 30$

142E EII AE 15

$14 \Xi E$ E $\triangle A$ A 17

1431 EI ER 16

1434 CI E 18

1437 EII FF III:

$143 \mathrm{H}$ こ1 हII 30

143II EII AE 15

1440 CI EF $1 E$

$1443 \geq 1$ EE 17

1446 CI EF $1 \mathrm{E}$

1449 EI E 15

144E DII EF $1 E$

$144 F$ ED 65 16

$145 \mathrm{E}$ EI FF OI:

$1455 \quad \Xi 1 \quad 04 \quad 30$

1458 CII AE 16

$145 \mathrm{ED}$ GF 15

$145 E$ E1 F3 17

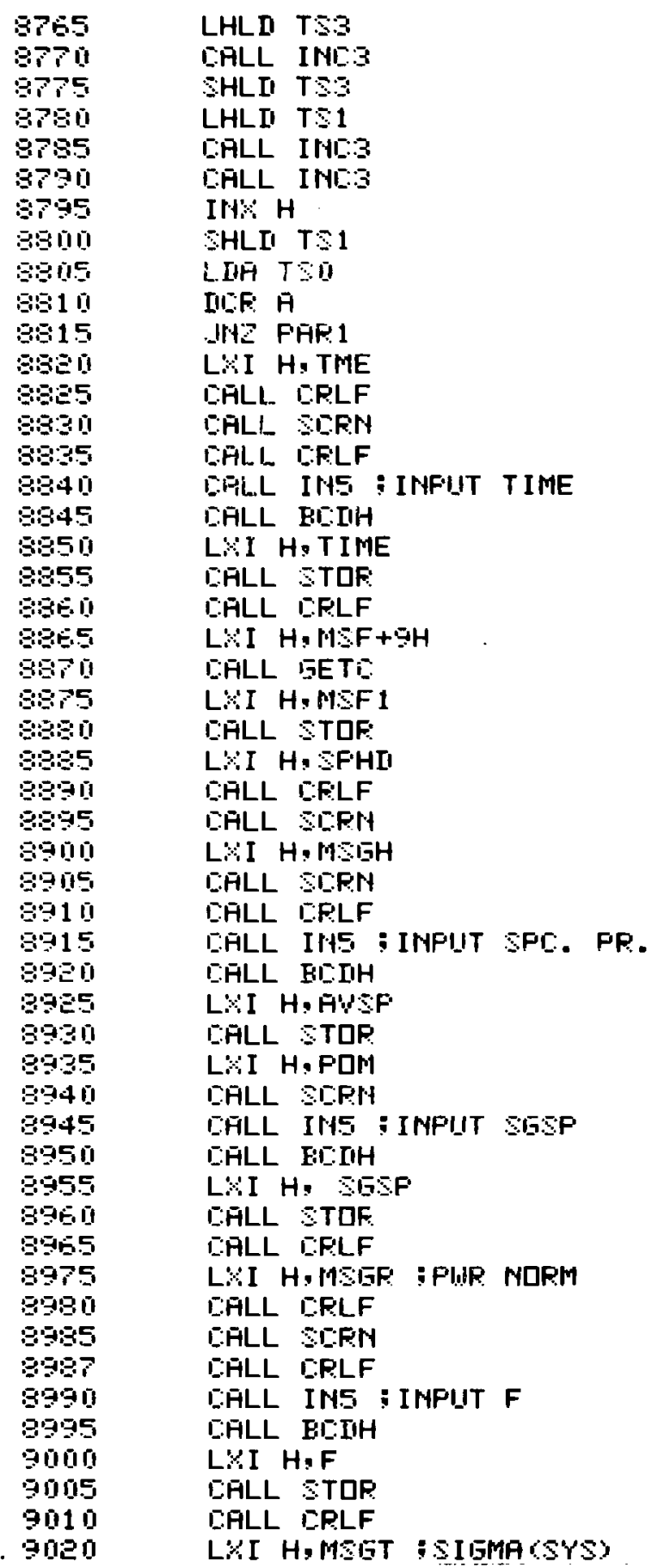




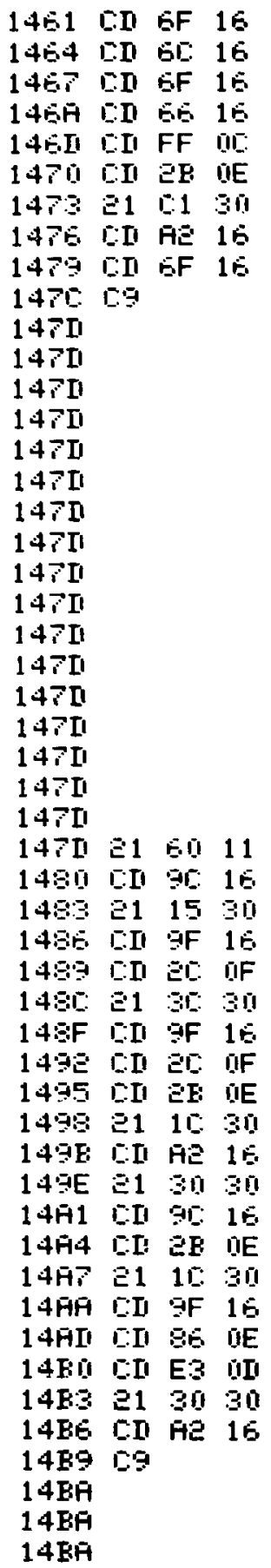

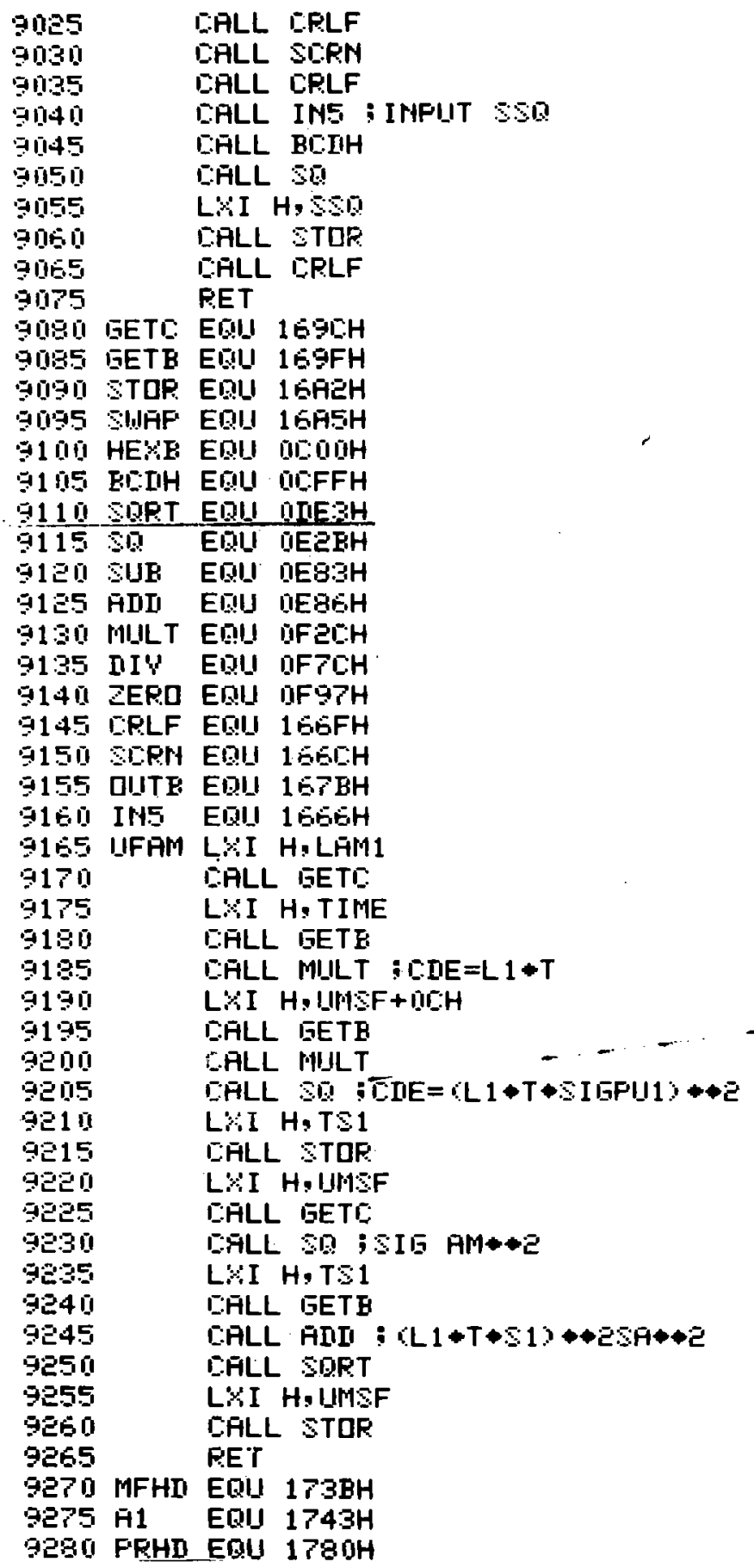




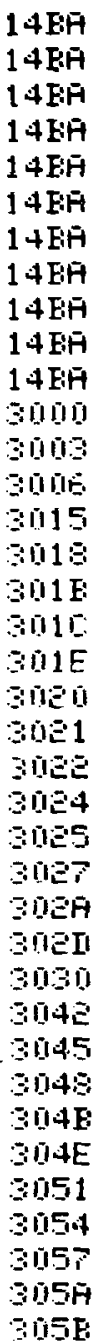

92B5 PDM EDII 17FAH 9290 TME EDI 17BDH 9205 SPHI EOII $1770 \mathrm{H}$ 9901 MSIG EQII $17 \mathrm{BEH}$

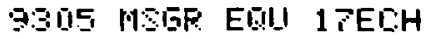
910 MSIT EDI $17 \mathrm{FSH}$ 9315 LEI ED! DIISEH 9SEU FLDT EIUI IIESYH $93{ }^{2} F$ EDL $304 \mathrm{H}$ 9920 SO EDI $301 \mathrm{H}$ 39E5 पFG $3000 \mathrm{HH}$ 9301 MSF IIS 3 9335 MSFA IS 3 930 MSF IIS DIFH 9345 TIME IIS 3 935 JINF IIS 3 395 TSU IIS 1 9301 IS 935 TSE IIS $E$ 930 TSO IIS 1 9375 TS5 IIS 1 9000 TS4 IIS $E$ 9385 TMF1 IL 1 939 TMFE ID: 935 TMPS IS 3 94010 AUF IIS 3 9405 15.F IIS 3 9410 JUAF IIS $1 \mathrm{EH}$ 9415 HLIF IS: 3 9420 FNY IS 3 94 ES FUNM IIS 3 9430 FluF I IIS 3 9435 NA IS 3 G440 SMME IS 3 9445 III IIS 3 9450 SMII IIS 3 9455 Hस IS 1 9460 raCP IIS 1 
APPENDIX C

\section{SIMPLIFIED OPERATING INSTRUCTIONS}

NO'TE: This synopsis is intended to be a check list for system operation. DO NOT OPERATE this device without first reading the more detailed instructions.

1. Select system 1 ine voltage (110 or $220 \mathrm{VAC}$ ).

2. Connect calorimeter unit to datamacquisition system.

3. Connect system power cord to bullding power.

4. Reset microprocessor ( $\mu \mathrm{P})$.

5. Monitor $\mu \mathrm{P}$ diagnostic test point \#1 $\left(\mathrm{T}_{3} \mathrm{~V}\right)$.

6. Insert dumny sample into measurement chamber. (It is recommended that the dumny sample have mass and thermal conductivity properties similar to the items being assayed.)

7. Insert capsule with first Pu-containing sample into preheater.

8. Wait for system to reach thermal equilibrium. (TP1 will read $\sim 5.3$ V. Total time $\sim 2$ hrs.) During this time, any additional sample encapsulation should be performed.

9. Start sample baseline analysis of dumny sample $\left(P_{0}\right)$.

$\begin{array}{lll}\text { Parameliers } & \text { DELAY-MIN } & -0 \\ & \text { SIGMA } \% & -0.02 \text { (St: tistical uncertainty only.) } \\ & \text { \#DP/RUN } & -100\end{array}$

10. Examine results of (9). Repeat (9) to ensure that system is actually at thermal equilibrium. 
11. Start thermal calibration (CAL).

$\begin{array}{lll}\text { Parameters } & \text { CAL PNTS } & -5 \\ & \text { DELAY-MIN } & -7 \\ & \text { SIGMA \% } & -0.02 \\ & \text { \#DP/RUN } & -100\end{array}$

12. Replace dumny sample with first Pu-containing capsule. Place next Pu-containing sample in preheater.

13. Enter sample assay parameters through INIT routine.
a) Sample isotopic data
b) Sample specific power
c) Correction to power normalization (PNORM)
d) Systematic measurement uncertainty [SIG(SY)]

14. Start sample assay.

$$
\begin{array}{lll}
\text { Parameters } & \text { DELAY-MIN } & -20 \\
& \text { SIGMA \% } & -0.2 \text { (Systematic uncertainty included.) } \\
& \text { \#DP/RIJN } & -100
\end{array}
$$

15. Repeat (12), (13). [A dummy sample should be run once every 4 samples to guard against baseline drift. This should be preceeded by an $\underline{\text { RST, }}$ and followed by reentering PNORM and SIG(SY)].

\section{EXPLANATION OF TYPICAL OUTPUT TAPE}

USER ACTION/RESPONSE

Press RST

Press $P_{0}$

Press ENTR (NO)
SYSTEM OUTPUT

SMALL SAMPLE READY

EMPTY MEAS

PRINT ALL? NO 
Input system equ111bration time

Iimit of acceptable measurement uncertainty

Input system assay time $\sim 25$ pnts/min

Power supplied by calorimetur to

maintain constant $T_{3}$

Assay will automatically be repeated

If

$\frac{\sigma\left(\overline{\mathrm{P}}_{0}\right)}{\overline{\mathrm{p}}}>$ SIGMA \%. Otherwise,

repetition is a user option

Prese CAL

Input reequilibration time

Reference input power

Calorimeter-supplied power $\begin{array}{lc}\text { DELAY-MIN } & 15 \\ \text { S IGMA-\% } & 0.02\end{array}$

$\# \mathrm{DP} / \mathrm{RUN} \quad 100$

POWER MW

$30.665+/-0.003$

AGAIN? YES

FOWER MW

$30.668+/-0.0028$

AGAIN? No

CALIBRATE

CAL PNTS 5

PRINT ALL? NO

DELAY-MIN 7

SIGMA \% $\quad 0.02$

\#DP/RUN 100

CALIBRATE MW

$4.7953+/-0.00212$

MEAS POWER MW

$26.075+/-0.03052$

CALIBRATE : N

$9.6148+/-0.00310$

MEAS POINER MW

$31.277+/-0.03907$ 
(Calorimeter-supplied power)

Press RST

Press INIT

Enter numeric, followed by ENTR

(NOTE: 0.004 , not .004)

NOTE: ${ }^{241}$ Am content should be entered relative to $\mathrm{Pu}$ value.
CALIBRATE MW

$14.419+/-0.00415$

MEAS POWER MW

$16.506+/-0.03319$

CALIBRATE MW

$19.288+/-0.00404$

MEAS POWER MW

$11.688+/-0.05019$

CALIBRATE MW

$23.897+/-0.00483$

MEAS POWER NiN

$7.1144+/-0.06305$

SMALL SAMPLE READY

DATA INPUT MASS \%

AM241

$0.24+/-0.004$

PU238

$0.0065+/-0.0008$

PU239

$95.24+/-0.01$

PU240

$4.6+/-0.11$ 
(Enter numeric)

Systematic measurement uncertainty

Press FRAC

Microprocessor calculated values for the sample isotopic composition.
PU241

$0.19+/-0.003$

PU242

$0.01+/-0.001$

\section{TIME-DAYS}

120

POWER MW/G

$+1-$

P INORM

1.0

SIG(SY)

0.023

MASS $\%$

AM241

0.24133

PU238

0.00648

PU239

95.195

PU240

4.5984

PU241

0.18841 
(Microprocessor-calculated values)

Press SP

Microprocessor-calculated sample

specific power $P_{\text {eff }}(\mathrm{mW} / \mathrm{g})$

Press RUN

System reequilibration time

following sample input

$\because 4-$ min assay

Calorimeter-supplied power $\left({ }_{\mathrm{c}}\right.$ )

Sample-supplied power $\overline{\mathrm{P}}_{S}=\overline{\mathrm{P}}_{0}-\overline{\mathrm{P}}_{c}$

Sample mass, $\overline{\mathrm{M}}_{\mathrm{Pu}}=\overline{\mathrm{P}}_{\mathrm{S}} / \mathrm{P}_{\text {eff }}$
PU242

0.00999

POWER MW

$2.4833+/-0.01131$

MEAS

PRINT ALL? NO

DELAY-MIN 15

SIGMA-\% $\quad 0.2$

\#DP/RUN $\quad 100$

MEAS POWER MW

$20.534+/-0.02817$

POWER MW

10.134

PU

$4.0810+/-0.0218$

AGAIN? YES

MEAS POWER MW

$20.540+/-0.02821$

POWER MW

10.128

PU

$4.0786+/-0.0218$

AGATN?

NO 